C A R F ワーキングペーパー

\begin{tabular}{|c|}
\hline CARF-J-028 \\
アジア太平洋のヘッジファンドの選択と \\
パフォーマンス分析 \\
東京大学大学院経済学研究科 \\
高橋 明彦 \\
GCI アセットマネシメント \\
袴田 武志 \\
東京大学大学院経済学研究科 \\
山本 匡 \\
2006 年8 8 \\
\end{tabular}

*現在、CARF は第一生命、日本生命、野村ホールディングス、みずほフィナンシャルグ ループ、三井住友銀行、三菱東京 UFJ 銀行、明治安田生命（五十音順）から財政的支 援をいただいております。CARF ワーキングペーパーはこの資金によって発行されてい ます。

CARF ワーキングペーパーの多くは 以下のサイトから無料で入手可能です。

http://www.carf.e.u-tokyo.ac.jp/workingpaper/index_j.cgi

このワーキングペーパーは、内部での討論に資するための未定稿の段階にある論文草稿で す。著者の承諾無しに引用・複写することは差し控えて下さい。 


\title{
アジア太平洋のヘッジファンドの選択と パフォーマンス分析*
}

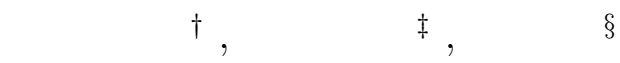

2006 年 8 月 8 日

\begin{abstract}
概 要
本論文は在アジア及びアジア太平洋を投資対象とするヘッジファンド のポートフォリオ構築 (Fund of Funds) とパフォーマンス分析を検討す る。特に、Eurekahedge database から抽出したアジア関連ヘッジファン ドに関し产のリターンの特性を調査すると共に、ヘッジファンドのポー トフォリオ構成方法を論じる。さらにヘッジファンドのリターンを株価 インデックスなどの市場で観測できるリスクファクターとファンドの付 加価值 (alpha) に分解しパフォーマンス分析を行う。最後に、これらの 分析を統合し、実際のファンド・オブ・ファンズ運用への適用を試みる。
\end{abstract}

*本論文は日本ファイナンス学会 14 回大会における研究報告論文を改訂したものである。本 稿の作成にあたり、大会討論者である法政大学金ヨンジン助教授から貴重なコメントを頂戴しま した。この場を借りて謝辞を申し上げます。なお、本稿で示されている内容および意見は筆者た ち個人に属し、GCI アセットマネジメントの見解を示すものではない。また、ありうべき誤り はすべて筆者たち個人に属する。

†東京大学経済学研究科

$\ddagger_{\text {GCI アセット・マネジメント }}$

$\S$ 東京大学経済学研究科 


\title{
Selection and Performance Analysis of Asia-Pacific Hedge Funds
}

Takeshi Hakamada* ${ }^{*}$ Akihiko Takahashi ${ }^{\dagger}$, and Kyo Yamamoto ${ }^{\ddagger}$

August 8, 2006

\begin{abstract}
This paper studies portfolio selection and performance analysis of hedge funds whose locations or investment targets are Asian-Pacific region. Utilizing Eurekahedge database, we investigate the characteristics of the funds' returns and optimization methods to create a fund of funds. Moreover, we decompose the returns of the hedge funds into risk factors which are observable in financial markets such as stock indices. Then, we attempt to manage a fund of funds by applicating those analyses.
\end{abstract}

${ }^{*}$ GCI Asset Management, Inc.

University of Tokyo

†niversity of Tokyo 


\section{1 はじめに}

アジアのヘッジファンドは、 2000 年から非常に良好な成長を示しており、 運用資産が毎年 $35 \%$ も伸びている。また、アジアは世界でもトップクラスの 運用機関数社の本拠地となっている。今後更にアジアのヘッジファンドは世 界で非常に重要な投資機関になっていくことが予想される。

過去のヘッジファンドのリターンの実証研究によりヘッジファンドには株 式、債券また投資信託などの従来の金融資産とは異なったリスクがあること が明らかになってきた。ヘッジファンドはレバレッジをかけることにより特 定のリスクを大きくとっている場合や、リターンが原資産に対して非線形に 反応する場合がある。我々は在アジアおよびアジア太平洋を投資対象とする ヘッジファンドのポートフォリオ構築という観点から、実証研究を行う。

Fung and Hsieh (1997, 1999, 2000a, 200b, 2001, 2002a, 2002b, 2004a, 2004b) の一連の実証研究によりヘッジファンドはロングオンリーの戦略ではとるこ とのできないリスクファクターへのエクスポージャーをとっていることが明ら かになり、また Agarwal and Naik (2004) は負のテイルリスクの重要性を指摘 した。これらの結果からヘッジファンドのリターンが正規分布に従うとは考え 難い。我々はまず、Eurekahedge database からアジア関連ヘッジファンドを抽 出し、弚のリターンが正規分布に従うという仮説の検定を行う。検定の結果、 アジア関連ヘッジファンドのリターンも正規分布に従うとは言えないものが 多く見受けられた。このことから、ヘッジファンドのリスクは標準偏差だけ では捉えきれない。ヘッジファンドのリターンの負のテイルリスクを考慮す るために次の二つのリスク指標を導入する。一つ目は conditional value-at-risk (CVaR) である。信頼水準 90\% の CVaR とは 10\% の確率で被る損失の平均で あり、Artzner et al. (1999) によって提唱されたリスク指標として望ましいと 考えられる coherent という性質を満たす。(VaR はこの性質を満たさない。) 二つ目は conditional drawdown (CDD) である。ファンドのパフォーマンス評 価の際には最大ドローダウンが重要なリスク指標となる場合が多い。信頼水 準 90\% のCDD は過去に被ったドローダウンのうち悪い方から 10\% の平均を 表す。CDD の信頼水準を十分大きく取った場合、過去の一番大きなドローダ ウンのみを考慮することになるため、CDD は最大ドローダウンを含んだリス ク指標となる。

リターンの負のテイルリスクが重要となる場合、平均分散アプローチは有 効ではなくなる。また、テイルリスクをコントロールしながら動学最適化を 行うことも困難である。我々は CVaR, CDD を考慮に入れて近視眼的にポート フォリオの最適化を行う。ここでは、ヒストリカルデータからリターンの分布 をパラメトリックに推定するのではなく、リターンのヒストリカルデータを 乥のまま光のファンドのリターンの分布と見做して最適化を行う Rockafellar and Uryasev (2000,2002), Chekhlov et al. (2000) のアルゴリズムを利用する。 これは CVaRや CDD に制約を加え、次期の期待収益率を最大化するポート 
フォリオを構成するものである。このアルゴリズムは最適化問題を線形計画 法で解くことができ、非常に使い易いという利点もある。平均分散アプロー チを含め、手法による最適ポートフォリオの違いを考察する。また、各手法 で運用した場合のパフォーマンスの違いを out-of-sample の結果で評価する。

fund of funds を運用する際には、リスクの分散が期待されるため、非常に 良いパフォーマンスをしているファンドが存在する場合においても一つのファ ンドに集中的に配分することは投資家の要望に反する場合がある。ここでは シングルファンドへの配分に資産の最大 $15 \%$ という制約を加え、上と同樣の 作業を行い、結果の比較を行う。

ヘッジファンドのパフォーマンス分析は Fung and Hsieh (1997, 1999, 2000a, 200b, 2001, 2002a, 2002b, 2004a, 2004b) や Agarwal and Naik (2004)などに よって研究されてきた。これらの研究によると、ヘッジファンドのリターンも 個別株や投資信託と同樣に株価インデックスなどのリスクファクターによっ て説明される場合が多い。ここでヘッジファンドのリターンか投資信託の关れ と大きく異なるのは、ショートやレバレッジの影響に加えてオプションのよう に株価インデックスに対して非線形に反応する場合があるということである。 理論上ではファンドのリターンはリスクファクターのリターンと光のファン ドの付加価值 (alpha) に要因分解することが出来る。我々は最適化によって選 択されたヘッジファンドに対し、リターンを株価インデックスなどの市場で 観測できるリスクファクターのリターンを説明変数として回帰分析を行うこ とにより要因分解を行う。本稿でリスクファクターとして採用したのは株価 インデックスとしてアジア各国の代表的な株価インデックスと S\&P500、名 ウ欧洲株価指数、ボンドインデックスとしてアジア各国と USA の MSCI bond index、各国の対米ドル為替レート、光して株価インデックスのオプションで ある。

Agarwal and Naik(2004) では event driven や distressed debt などの戦略をと るヘッジファンドは株価インデックスに対し、オプションのペイオフのよう に非線形なリターンを生む傾向があることが確認された。我々はまずファン ドのリターンを株価インデックス、ボンドインデックス、為替に要因分解し、 リスクファクターに対するファンドのリターンの反応の仕方を考察し、非線 形性が確認されたファンドに対して株価インデックスのオプションをリスク ファクターに加えて再び要因分解を行う。fixed incomeや distressed debt など の戦略をとるファンドに対してはクレジットスプレッドのインデックスがリ スクファクターとして期待されるが、データの取得が困難であるため、本稿 においてはこれを株価インデックスで代用する。

最後にポートフォリオ最適化とパフォーマンス分析を統合して、我々の手 法の実務への適用を示す。ここでは最適化によって選択されたへッジファンド の 2005 年のエクスポージャーを動的に捉え、最適ポートフォリオのリターン をリスクファクターと個別ファンドのアルファで再現することを試みる。こ 
の分析により情報の開示がそしいヘッジファンドに対してポートフォリオの 持つリスクを日々モニタリングすることができ、また高のリスクファクター が市場で取引されている場合には自身の見通しに基づいてェクスポージャー をコントロールすることが可能である。更に優れたヘッジファンドの alpha を 自己勘定のポジションにうまく取り込むことができれば理想的である。本稿 で検討する最適化手法やリスク分析は fund of funds 運用の際のポートフォリ 才構築やリスク管理への適用が期待される。

本稿の次節以下の構成は次の通りである。まず、2 節で在アジアおよびア ジア太平洋を投資対象とするヘッジファンドの正規性の検定と負のテイルリ スクの調査を行い、CVaR, CDD 最適化と平均分散アプローチによる最適ポー トフォリオを比較する。3 節ではヘッジファンドのリターンをリスクファク ターとファンドの付加価値に要因分解することによりパフォーマンス分析を 行う。さらに 2 節の最適化によって構築されたポートフォリオのリターンを リスクファクターとファンドのアルファによって再現することを試みる。最 後に、4 節で本稿の結論を述べる。

\section{2 アジア太平洋地域のヘッジファンドのリターンの 特性とポートフォリオ最適化}

Fung and Hsieh (1997, 1999, 2000a, 200b, 2001, 2002a, 2002b, 2004a, 2004b) の一連の実証研究によりヘッジファンドはロングオンリーの戦略ではとるこ とのできないリスクファクターへのエクスポージャーをとっていることが明 らかになり、また Agarwal and Naik (2004) は負のテイルリスクの重要性を指 摘した。これらの結果からヘッジファンドのリターンが正規分布に従うとは 考え難い。この節では、この特性がアジア太平洋地域のヘッジファンドにも あてはまるかどうかを調査し、弚の上で適切な最適化手法について論ずる。 ただし、本節ではリターンの分布の正規性と負のテイルリスクに焦点をあて、 オプション性やレバレッジの影響は3 節で見ることにする。2.1でヘッジファ ンドのリターンの正規性と負のテイルリスクについて調査し、2.2でヘッジ ファンドのポートフォリオを構成するための手法を検討する。光して、2.3で 各手法で実際に運用した時のパフォーマンスを評価する。

\section{1 アジア太平洋地域のヘッジファンドのリターンの特性}

まず、Eurekahedge database から在アジアおよびアジア太平洋を投資対象と するヘッジファンドを抽出し、弚のリターンに対し D'Agostino-Pearson 検定 を行う。抽出したファンドは 2001 年 1 月から 2005 年 12 月までの月次のヒス トリカル・データがあり、総数は全部で 108 である。表 1,2 は光れ艺れ戦略、 投資対象地域別のファンド数である。D'Agostino-Pearson 検定は標本の分布 
の尖度と歪度から正規性を検定するものである。ヘッジファンドのリターン に対し、D’Agostino-Pearson 検定を行った結果の p -値を表 3 に示した。また 比較対照としてにアジア太平洋地域の 37 の株価インデックスのリターンの $\mathrm{p}$-值も示した。この $\mathrm{p}$-值の表す意味は、例えば $\mathrm{p}$-值が $5 \%$ であるとは、光の ファンドのリターンが正規分布に従うと仮定した場合、実現したリターンが 起こる確率が $5 \%$ であるということである。

\begin{tabular}{cccc}
\hline 投資戦略 & Long / Short Equities & Distressed Debt & Multi-Strategy \\
\hline ファンド数 & 58 & 5 & 17 \\
\hline \multicolumn{5}{c}{} & & & \\
\hline Relative Value & Fixed Income & Arbitrage & CTA \\
\hline 6 & 4 & 3 & 5 \\
\hline CTA / Managed Futures & Macro & Event Driven & Others \\
\hline 1 & 5 & 2 & 2 \\
\hline
\end{tabular}

表 1: 戦略別ファンド数

\begin{tabular}{cccc}
\hline 投資対象地域 & Asia incl Japan & Asia ex-Japan & Korea \\
\hline ファンド数 & 21 & 15 & 2 \\
\hline & & & \\
\hline Global & Emerging Markets & Japan Only & India \\
\hline 20 & 13 & 26 & 1 \\
\hline
\end{tabular}

\begin{tabular}{ccc}
\hline Greater China & Australia / New Zealand & Taiwan \\
\hline 1 & 8 & 1 \\
\hline
\end{tabular}

表 2: 地域別ファンド数

\begin{tabular}{|c|c|c|c|c|c|}
\hline D'Agostino-Pearson 検定 $\mathrm{p}$ 值 & $0 \% \sim 5 \%$ & $5 \% \sim 10 \%$ & $10 \% \sim 20 \%$ & $20 \% \sim 50 \%$ & $50 \% \sim 100 \%$ \\
\hline ファンド数 & 49 & 5 & 6 & 29 & 19 \\
\hline D'Agostino-Pearson 検定 $\mathrm{p}$ 值 & $0 \% \sim 5 \%$ & $5 \% \sim 10 \%$ & $10 \% \sim 20 \%$ & $20 \% \sim 50 \%$ & $50 \% \sim 100 \%$ \\
\hline index 数 & 5 & 0 & 4 & 5 & 23 \\
\hline
\end{tabular}

表 3: ヘッジファンドと株価 index のリターンの D'Agostino-Pearson 検定 p-值

表 3 に示した通り、半数近くのヘッジファンドのリターンの $\mathrm{p}$-值は $0 \%$ $5 \%$ の範囲にあり、リターンが正規分布に従うとは言い難いものが多い。一 方、半数以上の株価インデックスのリターンの p-值が $50 \%$ ～100\% の範囲に 
あり、株価インデックスに比ベ、ヘッジファンドのリターンの従う分布が正 規分布から大きく乘離していることが確認できる。

リターンが正規分布に従うとは言えない場合、標準偏差だけではリスクは 捉えきれず、負のテイルリスクを考える必要がある。各ファンドの負のテイル リスクを表す指標として次の二つを考える。一つ目は conditional value-at-risk (CVaR) である。例えば、信頼水準 $90 \%$ の CVaR とは $10 \%$ の確率で被る損失 の平均を表す。CVaR は Artzner et al.(1999) で提唱された coherent というリス ク指標として望ましい性質を持つ。一方、VaR はこの性質を満たさない。二 つ目は conditional drawdown (CDD) である。ファンドのパフォーマンス評価 の際には最大ドローダウンが重要なリスク指標となる場合が多い。信頼水準 90\% の CDD とは、過去に被ったドローダウンのうち悪い方から $10 \%$ の平均 を表す。CDD の信頼水準を十分大きく取った場合、過去の一番大きなドロー ダウンのみを考慮することになり、CDD は最大ドローダウンを含んだリスク 指標となる。

ここで、CVaR, CDD の数学的な定義を述べる。 $R^{i}$ である1期間でのヘッジ ファンド $i$ の収益率の確率変数を表すとすると、光のファンドの損失率は $-R^{i}$ であり、この累積分布関数を $\Psi_{R^{i}}(\zeta)$ で表す。すなわち、 $\Psi_{R^{i}}(\zeta)=P\left[-R^{i} \leq \zeta\right]$ である。CVaR の定義をする前にVaR の定義を述べておく。

定義 1 ファンド $i$ の信頼水準 $100 \alpha \%$ の VaR $V_{\alpha}^{i}$ は

$$
V_{\alpha}^{i}=\min \left\{\zeta \mid \Psi_{R^{i}}(\zeta) \geq \alpha\right\}
$$

で定義される。

CVaR は次のように定義される。

定義 2 ファンド $i$ の信頼水準 $100 \alpha \%$ の CVaR $\phi_{\alpha}^{i}$ を

$$
\phi_{\alpha}^{i}=E\left[-R^{i} \mid-R_{i} \geq V_{\alpha}^{i}\right]
$$

で定義する。ここで条件付期待値の累積分布関数 $\Psi_{R^{i}}^{\alpha}(\zeta)$ は次の通りである。

$$
\Psi_{R^{i}}^{\alpha}(\zeta)= \begin{cases}0 & \text { for } \zeta<V_{\alpha}^{i}, \\ \frac{\Psi_{R^{i}}(\zeta)-\alpha}{1-\alpha} & \text { for } \zeta \geq V_{\alpha}^{i} .\end{cases}
$$

次に CDD の定義を述べる。ここで、ドローダウンの定義は通常用いられる ドローダウンの定義と若干異なるが、ここでは後の最適化問題を線形計画に 帰着させるために Chekhlov et al. (2000) の定義を用いることにする。第 $\mathrm{t}$ 期 のファンド $i$ の収益率を $R_{t}^{i}$ とおき、 $v_{\tau}^{i}=1+\sum_{s=1}^{\tau} R_{s}^{i}$ とおく。つまり、 $v_{\tau}^{i}$ は複 利なしでファンド $i$ で運用した時の $\tau$ 時点での資産を表す。 
定義 3 ファンド $i$ の $t$ 時点でのドローダウン $d_{t}^{i}$ を

$$
d_{t}^{i}=\max _{0 \leq \tau \leq t}\left\{v_{\tau}^{i}\right\}-v_{t}^{i}
$$

で定義する。次に信頼水準 $100 \alpha \%$ の conditional drawdown (CDD) を定義する。 $\left\{d_{1}^{i}, \cdots, d_{T}^{i}\right\}$ を大きい順に並べ替えたものを $\left\{\hat{d}_{1}^{i}, \cdots, \hat{d}_{T}^{i}\right\}$ とし、 $\frac{k-1}{T}<1-\alpha \leq \frac{k}{T}$ であるとする。この時、信頼水準 $100 \alpha \%$ の conditional drawdown $D_{\alpha}^{i}$ を

$$
D_{\alpha}^{i}=\frac{\sum_{t=1}^{k-1} \hat{d}_{t}^{i}}{(1-\alpha) T}+\left\{1-\frac{k-1}{(1-\alpha) T}\right\} \hat{d}_{k}^{i}
$$

で定義する。

利用したヘッジファンドの月次の平均リターン、標準偏差、CVaR, CDD (共 に信頼水準 90\%) を計算し、図 1-3に横軸に各リスク指標、縦軸に平均リター ンをとってプロットした。

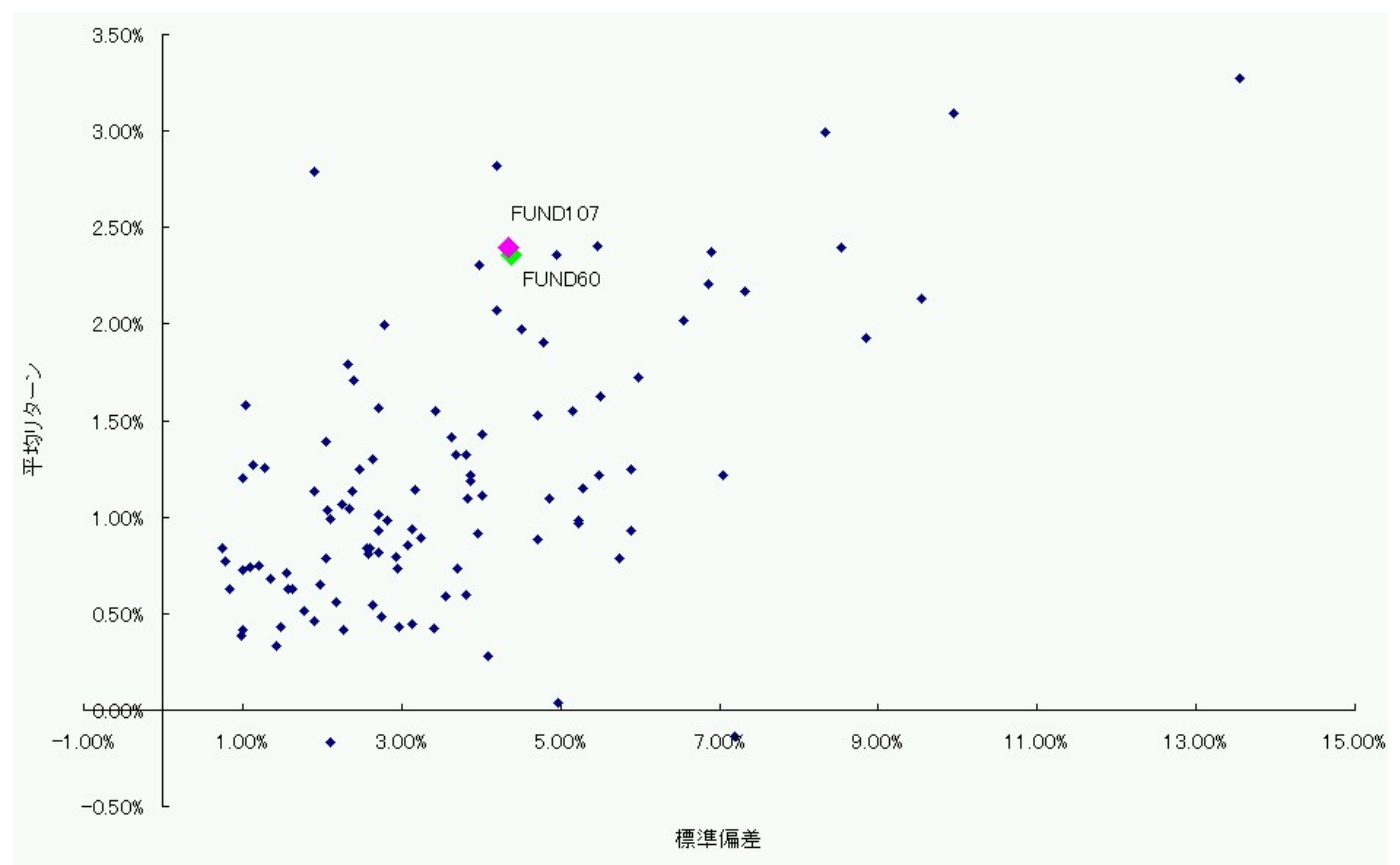

図 1: 平均-標準偏差

平均-標準偏差で評価した場合、似たパフォーマンスをしていると判断され るファンドでも CVaR, CDD が大きく異なる場合があることか確認される。例 えば、FUND60 と FUND107 の月次の平均リターン、標準偏差が弚れぞれ、 $2.36 \%, 4.38 \%$ と 2.40\%, 4.34\% である一方で、CVaR, CDD (共に信頼水準 90\%) は $5.12 \%, 11.65 \%$ と 2.87\%,3.71\% であり、FUND60 の方が負のテイルリスク が大きい。このことからもへッジファンドのリターンの場合には標準偏差だ けでは負のテイルリスクを捉え切れていないことが分かる。 


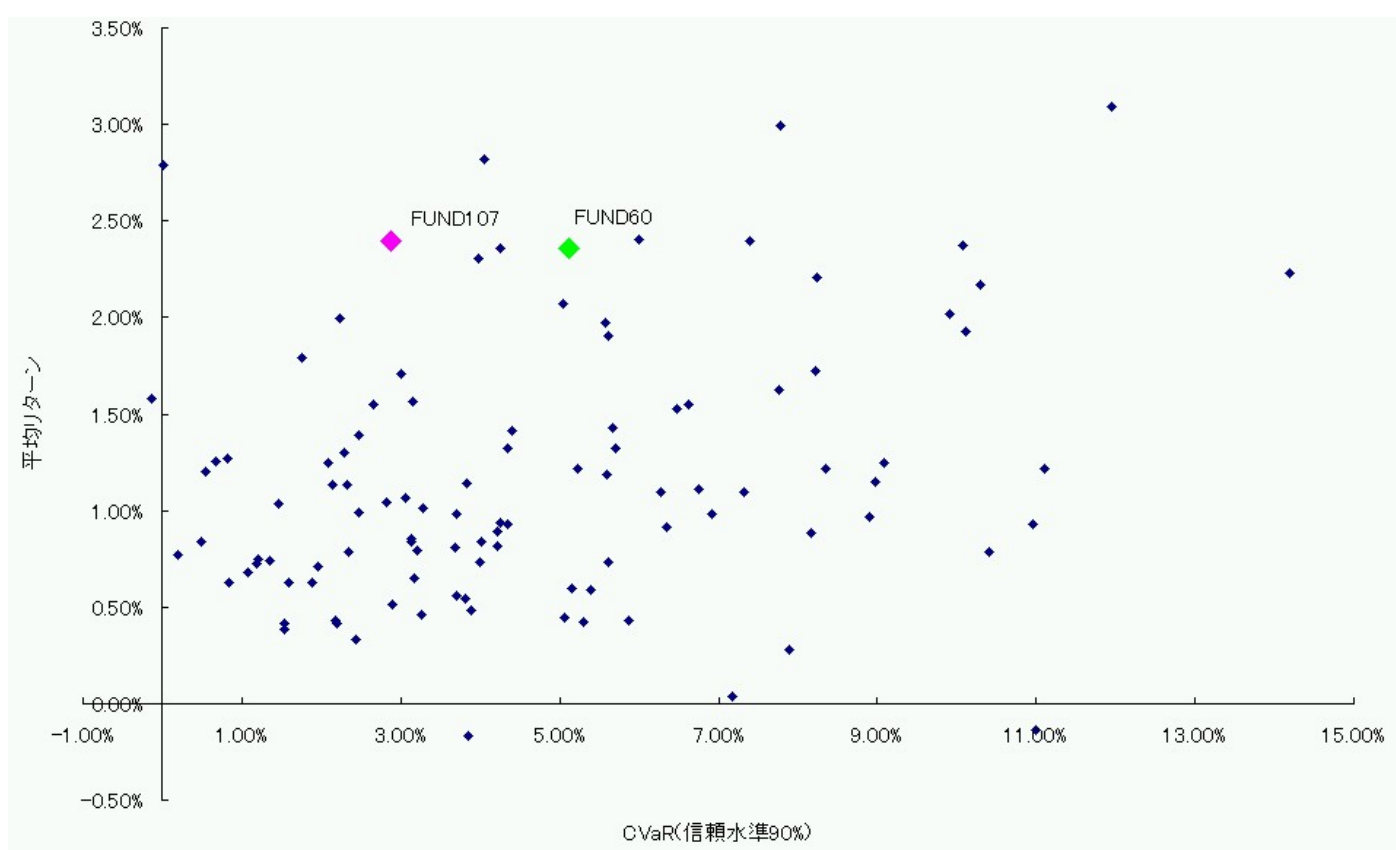

図 2: 平均-CVaR

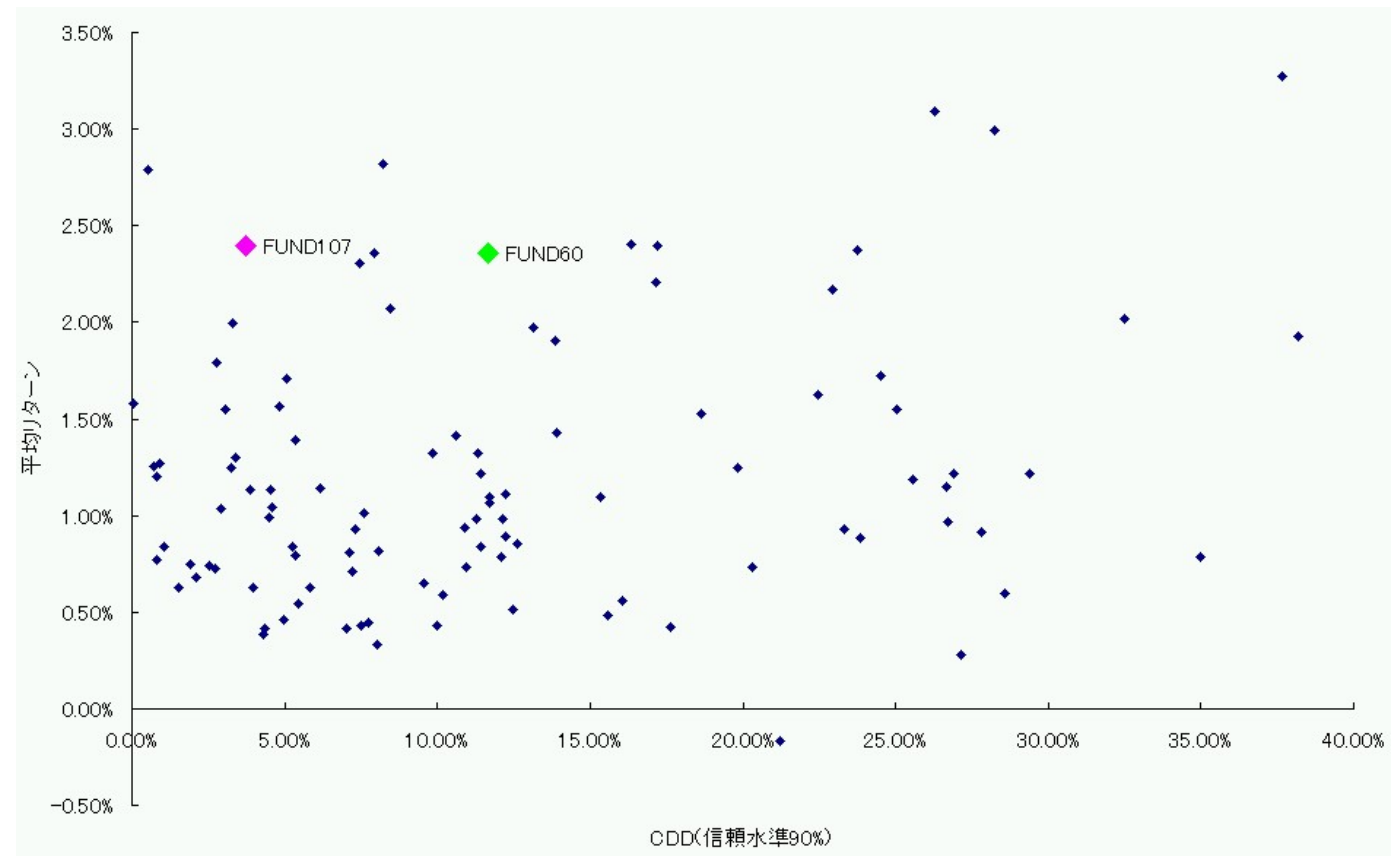

図 3: 平均-CDD 


\section{2 ヘッジファンドのポートフォリオ最適化}

平均分散アプローチでは標準偏差をリスクと捉えた。これは証券のリター ンが正規分布などの分布に従う場合か投資家の効用が二次効用であると仮定 した場合に正当化される最適化手法である。2.1でアジア太平洋地域のヘッジ ファンドのリターンは正規分布に従うとは言えず、負のテイルリスクが重要 となることを確認した。この場合、平均分散アプローチは適切な最適化手法 とは言い難い。以下では CVaR, CDD に焦点を当てた最適化手法を導入し、平 均分散アプローチとの比較を行う。

$\mathrm{n}$ ファンドのユニバースに一定期間投資し、リスクをある基準内に抑えなが ら光の間の期待収益率を最大化することを考える。 $\mathbf{r}=\left(r_{1}, \cdots, r_{n}\right)^{\prime}$ で各ファ ンドのこの期間での収益率の $\mathbf{R}^{n}$-值確率変数を表すものとする。さらに $\Phi(\mathbf{x})$ でポートフォリオ $\mathbf{x}$ のあるリスク指標を表す。このような設定の下で最適化 問題は次のように書くことができる。

$$
\max _{\mathbf{x}} E\left[\mathbf{r}^{\prime} \mathbf{x}\right]
$$

s.t.

$$
\begin{gathered}
0 \leq x_{i} \leq 1, \quad i=1, \cdots, n, \\
\sum_{i=1}^{n} x_{i} \leq 1,
\end{gathered}
$$

$\Phi(\mathbf{x}) \leq \omega$.

ここで $\omega$ はリスク許容度を表す。 $\Phi(\mathbf{x})$ として我々は CVaR, CDD の 2 つを考 える。これらをリスク指標と考えた場合、Rockafellar and Uryasev (2000,2002) , Chekhlov et al. (2000) のアルゴリズムにより最適化問題を容易に解くことが できる。この手法はリターンの過程をパラメトリックに仮定し、パラメータ を推定してから問題を解くのではなく、リターンに関して全く仮定を置かず にヒストリカルリターンを关のままリターンの分布と見做して問題を解くサ ンプルパス・アプローチである。ここで、最適化問題を線形計画に帰着させ る次の定理を述べておく。

定理 $1 \zeta$ の関数として、

$$
\begin{gathered}
\zeta+\frac{1}{1-\alpha} E\left[\left(-\mathbf{r}^{\prime} \mathbf{x}-\zeta\right)_{+}\right], \\
\zeta+\frac{1}{1-\alpha} \frac{1}{T} \sum_{t=1}^{T}\left(d_{t}^{\mathbf{x}}-\zeta\right)_{+}
\end{gathered}
$$

は有限值をとり、凸関数である。さらに、

$$
\phi_{\alpha}^{\mathbf{x}}=\min _{\zeta}\left\{\zeta+\frac{1}{1-\alpha} E\left[\left(-\mathbf{r}^{\prime} \mathbf{x}-\zeta\right)_{+}\right]\right\},
$$




$$
D_{\alpha}^{\mathbf{x}}=\min _{\zeta}\left\{\zeta+\frac{1}{1-\alpha} \frac{1}{T} \sum_{t=1}^{T}\left(d_{t}^{\mathbf{x}}-\zeta\right)_{+}\right\} .
$$

(証明はUryasev(2001).)

定理 1 により $T$ 期分のヒストリカル・データがある時、第 $t$ 期のファンド の収益率のベクトルを $\mathbf{r}_{t}$ と書くとリスク指標として CVaR を考えた場合の最 適化問題の式 (1),(4) は乥れ光れ次のように書き直すことができる。

$$
\begin{gathered}
\max _{\mathbf{x}} \frac{1}{T} \sum_{t=1}^{T} \mathbf{r}_{t}^{\prime} \mathbf{x}, \\
\zeta+\frac{1}{1-\alpha} \frac{1}{T} \sum_{t=1}^{T}\left(-\mathbf{r}_{t}^{\prime} \mathbf{x}-\zeta\right)_{+} \leq \omega, \zeta \in \mathbf{R} .
\end{gathered}
$$

式 (6) は次の線形不等式に書き直せるため、CVaR 最適化問題は線形計画に帰 着する。

$$
\begin{gathered}
\zeta+\frac{1}{1-\alpha} \frac{1}{T} \sum_{t=1}^{T} w_{t} \leq \omega, \\
-\mathbf{r}_{t}^{\prime} \mathbf{x}-\zeta \leq w_{t}, \quad t=1, \cdots, T, \\
\zeta \in \mathbf{R}, w_{t} \geq 0, t=1, \cdots, T .
\end{gathered}
$$

また、定理 1 により $T$ 期分のヒストリカル・データがある時、リスク指標と して CDD を考えた場合の最適化問題の式 (1),(4) は乥れ次のように書き 直すことができる。

$$
\begin{gathered}
\max _{\mathbf{x}} \frac{1}{T} \sum_{t=1}^{T} \mathbf{r}_{t}^{\prime} \mathbf{x}, \\
\zeta+\frac{1}{1-\alpha} \frac{1}{T} \sum_{t=1}^{T}\left(\max _{1 \leq s \leq \mathrm{t}} \sum_{\tau=1}^{s} \mathbf{r}_{\tau}^{\prime} \mathbf{x}-\sum_{\tau=1}^{t} \mathbf{r}_{\tau}^{\prime} \mathbf{x}-\zeta\right)_{+} \leq \omega, \zeta \in \mathbf{R} .
\end{gathered}
$$

式(9) は次の線形不等式に書き直せるため、最適化問題は線形計画に帰着する。

$$
\begin{gathered}
\zeta+\frac{1}{1-\alpha} \frac{1}{T} \sum_{t=1}^{T} z_{t} \leq \omega, \\
z_{t} \geq u_{t}-\sum_{\tau=1}^{t} \mathbf{r}_{\tau}^{\prime} \mathbf{x}-\zeta, \quad 1 \leq t \leq T, \\
z_{t} \geq 0, \quad 1 \leq t \leq T, \\
u_{t} \geq \sum_{\tau=1}^{t} \mathbf{r}_{\tau}^{\prime} \mathbf{x}, \quad 1 \leq t \leq T, \\
u_{t} \geq u_{t-1}, \quad 1 \leq t \leq T, \\
u_{0}=0 .
\end{gathered}
$$


以下では、2.1 でEurekahedge database から抽出したヘッジファンドをユニ バースとして CVaR,CDD に制約を加えてポートフォリオの最適化を行い、最 適ポートフォリオの平均分散最適ポートフォリオとの違いを検証する。この 際、安全資産として1ヶ月のUS LIBOR をユニバースに加える。ファンドの ヒストリカルデータは 2001 年 1 月から 2005 年 12 月の月次リターンであり、 これを in-sample として最適ポートフォリオを求める。

まず、CVaR 最適ポートフォリオについて考察する。ここでは信頼水準を $90 \%$ とし、リスク許容度は $0.1 \%, 0.5 \%, 1 \%, 3 \%, 5 \%$ として最適ポートフォリ 才を求めた。表 4 に配分されたファンドと关のウェイト、各リスク指標を示 した。また、图 4 に選択されたファンドを示した。

\begin{tabular}{cccccc}
\hline リスク許容度 & $0.10 \%$ & $0.50 \%$ & $1.00 \%$ & $3.00 \%$ & $5.00 \%$ \\
\hline FUND18 & $0.39 \%$ & $2.13 \%$ & $4.01 \%$ & $7.05 \%$ & $10.58 \%$ \\
FUND23 & $2.12 \%$ & $4.76 \%$ & $11.17 \%$ & $20.12 \%$ & $28.72 \%$ \\
FUND72 & $4.39 \%$ & $12.36 \%$ & $12.27 \%$ & $28.30 \%$ & $41.77 \%$ \\
FUND98 & $93.10 \%$ & $80.76 \%$ & $72.55 \%$ & $44.53 \%$ & $18.94 \%$ \\
\hline 期待収益率 & $2.81 \%$ & $2.85 \%$ & $2.88 \%$ & $2.97 \%$ & $3.05 \%$ \\
標準偏差 & $1.89 \%$ & $2.12 \%$ & $2.58 \%$ & $4.04 \%$ & $5.60 \%$ \\
$\mathrm{CVaR}($ 信頼水準 $90 \%)$ & $0.10 \%$ & $0.50 \%$ & $1.00 \%$ & $3.00 \%$ & $5.00 \%$ \\
$\mathrm{CDD}$ (信頼水準 $90 \%)$ & $0.44 \%$ & $0.65 \%$ & $1.21 \%$ & $3.69 \%$ & $8.15 \%$ \\
\hline
\end{tabular}

表 4: CVaR(信頼水準 90\%) 最適ポートフォリオ

上で述べた CVaR 最適ポートフォリオを求めるアルゴリズムは CVaR をリ スク許容度に抑えながら、期待収益率を最大化するものである。この手法に よるとまず期待収益率の高いファンドから選択し、残りの部分を谷のファン ドが損失を被る時に損失を被らないファンドで期待収益率の高いファンドに 配分することになる。今回利用したヘッジファンドの中で最も期待収益率が 高いのは FUND23 の $3.27 \%$ であり、リスク許容度か許す範囲で FUND23 か ら期待収益率の高い順に配分していく。このため、リスク許容度を小さくす るにつれて、期待収益率が高く CVaR も大きい FUND18, FUND23, FUND72 への配分が少なくなる。一方、リスク許容度を小さくするにつれ、FUND 98 への配分が高くなる。FUND98 の期待収益率は $2.79 \%$ と高く、信頼水準 $90 \%$ の CVaR は $0.01 \%$ と非常に小さい。したがって、CVaRをリスクと見做した 場合は FUND98 はほぼ無リスクのファンドとなる。リスク許容度を小さくす るにつれ FUND98 の配分か増えるのは、許容度に収まらない部分を FUND98 に配分していくためである。CVaR 最適化はこの樣なファンドを高い収益の 期待できる安全資産と見做し、リスク許容度か許す分だけ光のファンドより 期待収益率が大きくてリスキーなファンドに配分する、ということもできる。 また、リスク許容度を小さくすると、標準偏差、CDD も小さくなっているこ 


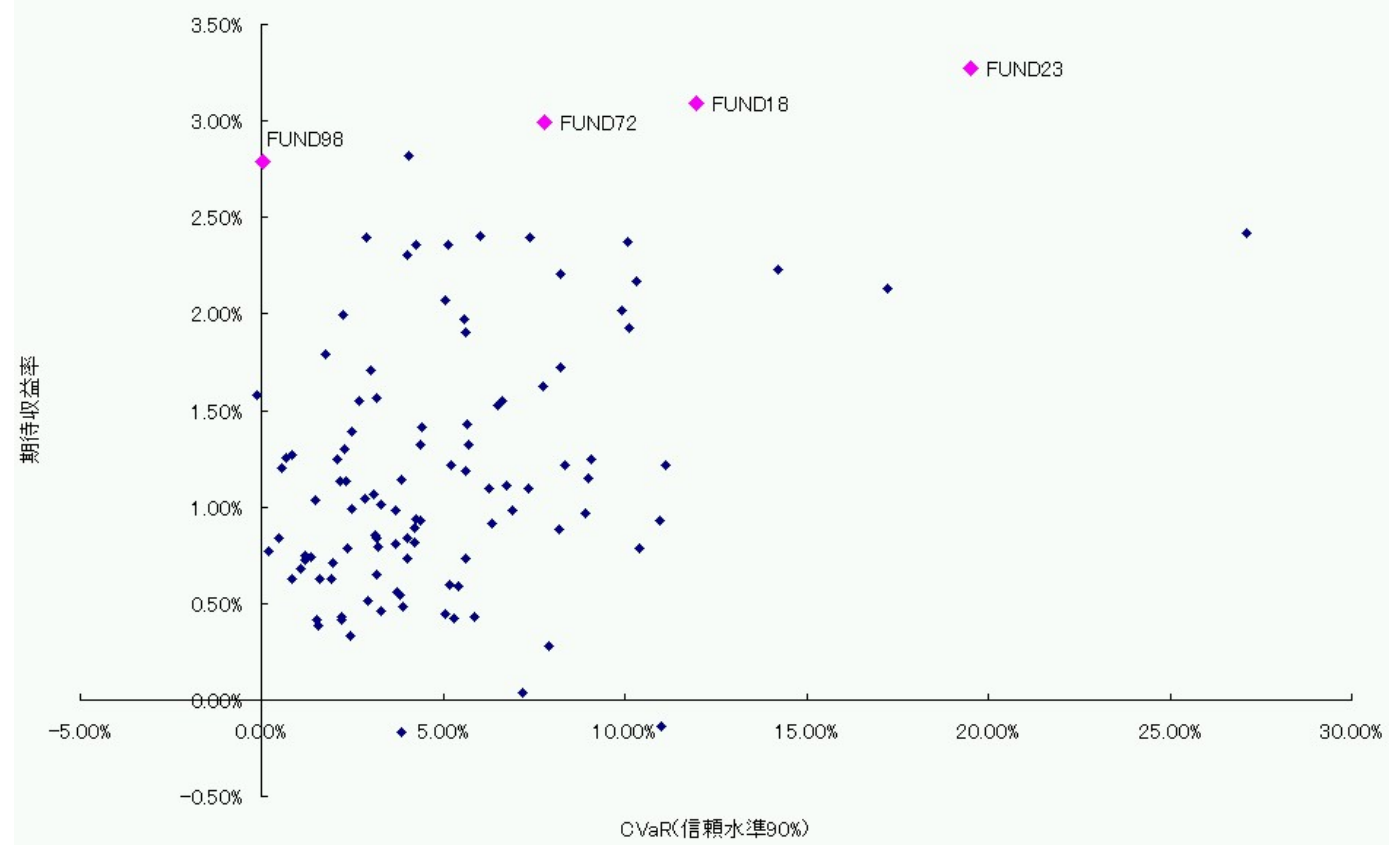

図 4: CVaR 最適化で選択されたファンド

とが確認できる。各リスク指標の定義の違いからこのようなことが常に成立 するとはいえないが、今回 CVaR 最適化で選択されたファンドは CVaR が大 きいファンドは標準偏差、CDD も大きく、逆にCVaRが小さいファンドは標 準偏差、CDD も小さいため、CVaR リスク許容度を小さくすると他のリスク 指標も小さくなる。

次に、CDD 最適ポートフォリオを求める。CVaR と同樣に信頼水準を $90 \%$ とし、リスク許容度は $0.1 \%, 0.5 \%, 1 \%, 5 \%, 10 \%$ とした。表 5 に配分された ファンドと关のウェイト、各リスク指標を示した。また、图 5 に選択された ファンドを示した。 


\begin{tabular}{cccccc}
\hline リスク許容度 & $0.10 \%$ & $0.50 \%$ & $1.00 \%$ & $5.00 \%$ & $10.00 \%$ \\
\hline FUND13 & $17.84 \%$ & $0.00 \%$ & $0.00 \%$ & $0.00 \%$ & $0.00 \%$ \\
FUND18 & $0.00 \%$ & $0.00 \%$ & $2.97 \%$ & $3.31 \%$ & $8.96 \%$ \\
FUND23 & $5.01 \%$ & $3.28 \%$ & $10.94 \%$ & $27.22 \%$ & $44.26 \%$ \\
FUND29 & $1.86 \%$ & $0.00 \%$ & $0.00 \%$ & $0.00 \%$ & $0.00 \%$ \\
FUND49 & $1.59 \%$ & $0.00 \%$ & $0.00 \%$ & $0.00 \%$ & $0.00 \%$ \\
FUND72 & $0.00 \%$ & $9.16 \%$ & $10.90 \%$ & $32.08 \%$ & $31.38 \%$ \\
FUND73 & $11.69 \%$ & $0.00 \%$ & $0.00 \%$ & $0.00 \%$ & $0.00 \%$ \\
FUND79 & $2.29 \%$ & $0.00 \%$ & $0.00 \%$ & $0.00 \%$ & $0.00 \%$ \\
FUND88 & $0.00 \%$ & $0.00 \%$ & $0.00 \%$ & $0.00 \%$ & $14.00 \%$ \\
FUND91 & $3.59 \%$ & $0.00 \%$ & $0.00 \%$ & $0.00 \%$ & $0.00 \%$ \\
FUND98 & $56.13 \%$ & $87.56 \%$ & $75.19 \%$ & $37.38 \%$ & $1.40 \%$ \\
\hline 期待収益率 & $2.43 \%$ & $2.83 \%$ & $2.88 \%$ & $3.00 \%$ & $3.10 \%$ \\
標準偏差 & $1.75 \%$ & $1.95 \%$ & $2.51 \%$ & $4.88 \%$ & $7.01 \%$ \\
CVaR(信頼水準 $90 \%)$ & $0.10 \%$ & $0.33 \%$ & $0.97 \%$ & $4.26 \%$ & $7.60 \%$ \\
CDD(信頼水準 $90 \%)$ & $0.10 \%$ & $0.50 \%$ & $1.00 \%$ & $5.00 \%$ & $10.00 \%$ \\
\hline
\end{tabular}

表 5: $\mathrm{CDD}$ (信頼水準 90\%) 最適ポートフォリオ

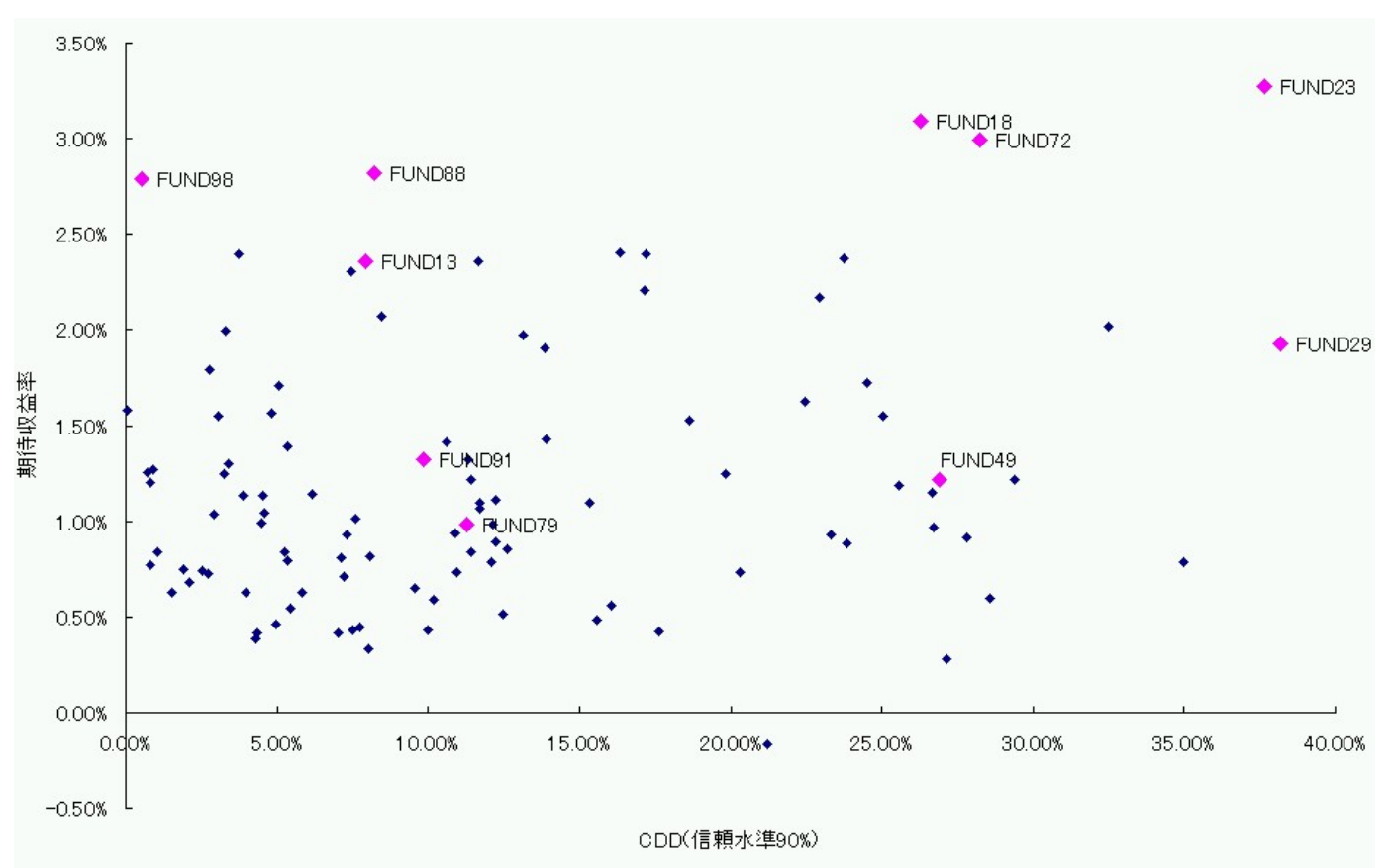

図 5: CDD 最適化で選択されたファンド 
CVaR の場合と同樣にCDD の場合もまず期待収益率の高いファンドから選 択し、残りの部分を产のファンドがドローダウンを被る時にドローダウンを被 らないファンドで期待収益率の高いファンドに配分する。したがって、CVaR の時と同樣にリスク許容度に収まる間は期待収益率が高い順から配分し、光 の後は FUND98 に配分する。しかし、FUND98 の信頼水準 90\% の CDD は $0.51 \%$ であるので、リスク許容度が $0.1 \%$ の時は FUND 98 も光のリスク許容 度に収まらない。したがって、FUND98 がドローダウンを被っている間にド ローダウンを被らないファンドに配分することになる。ここで配分されるの は FUND98 がドローダウンを被っている時にドローダウンを被っていない ファンドであり、弚のファンド自体の CDD が低い訳ではないことには注意す る必要がある。CDD 最適ポートフォリオの場合もリスク許容度を小さくする につれ、他のリスク指標も小さくなる。しかし、リスク許容度 $0.1 \%$ のCDD 最適ポートフォリオとリスク許容度 $0.1 \%$ の CVaR 最適ポートフォリオのリ スク指標を比べると、CDD 最適ポートフォリオの方が期待収益率が低く、標 準偏差、CDD も小さいため、CVaR 最適ポートフォリオよりコンサーバティ ブなポートフォリオといえる。しかし、CDD 最適ポートフォリオのCVaR は CVaR 最適ポートフォリオと同じ $0.1 \%$ である。

これらの手法で得られたポートフォリオと平均分散最適ポートフォリオの 違いを考察する。ここで、平均分散最適ポートフォリオとは月次のターゲッ トリターンを指定し、弚の期待収益率を達成するポートフォリオの中で分散 が最小となるポートフォリオである。CVaR, CDD 最適ポートフォリオとの比 較を行うため、リスク許容度 $0.1 \%$ の CVaR, CDD 最適ポートフォリオの期 待収益率 $2.81 \%, 2.43 \%$ を達成する平均分散最適ポートフォリオを求めた。図 6-9に CVaR, CDD 最適化によって選択されたファンドと光のウェイト、平均 分散アプローチによって選択されたファンドと炎のウェイトを示した。ファ ンド名の横の括弧内の前の数字が $\mathrm{CVaR}, \mathrm{CDD}$ 最適化によるウェイト、後ろの 数字が平均分散アプローチによるウェイトを表す。また、表 6 に平均分散最 適ポートフォリオの各リスク指標を示した。

\begin{tabular}{ccc}
\hline 期待収益率 & $2.43 \%$ & $2.81 \%$ \\
\hline 標準偏差 & $1.38 \%$ & $1.86 \%$ \\
$\mathrm{CVaR}($ 信頼水準 $90 \%)$ & $-0.23 \%$ & $0.21 \%$ \\
$\mathrm{CDD}($ 信頼水準 $90 \%)$ & $0.32 \%$ & $0.49 \%$ \\
\hline
\end{tabular}

表 6: 平均分散最適ポートフォリオのリスク指標

リスク指標を見ると、標準偏差が CVaR, CDD 最適ポートフォリオより小 さいことが確認できる。また、CVaR, CDD も非常に小さい。この原因は後 に明らかにすることにして、まず $\mathrm{CVaR}$ 最適ポートフォリオと平均分散最適 ポートフォリオの違いを考察する。CVaR 最適ポートフォリオでは FUND98 


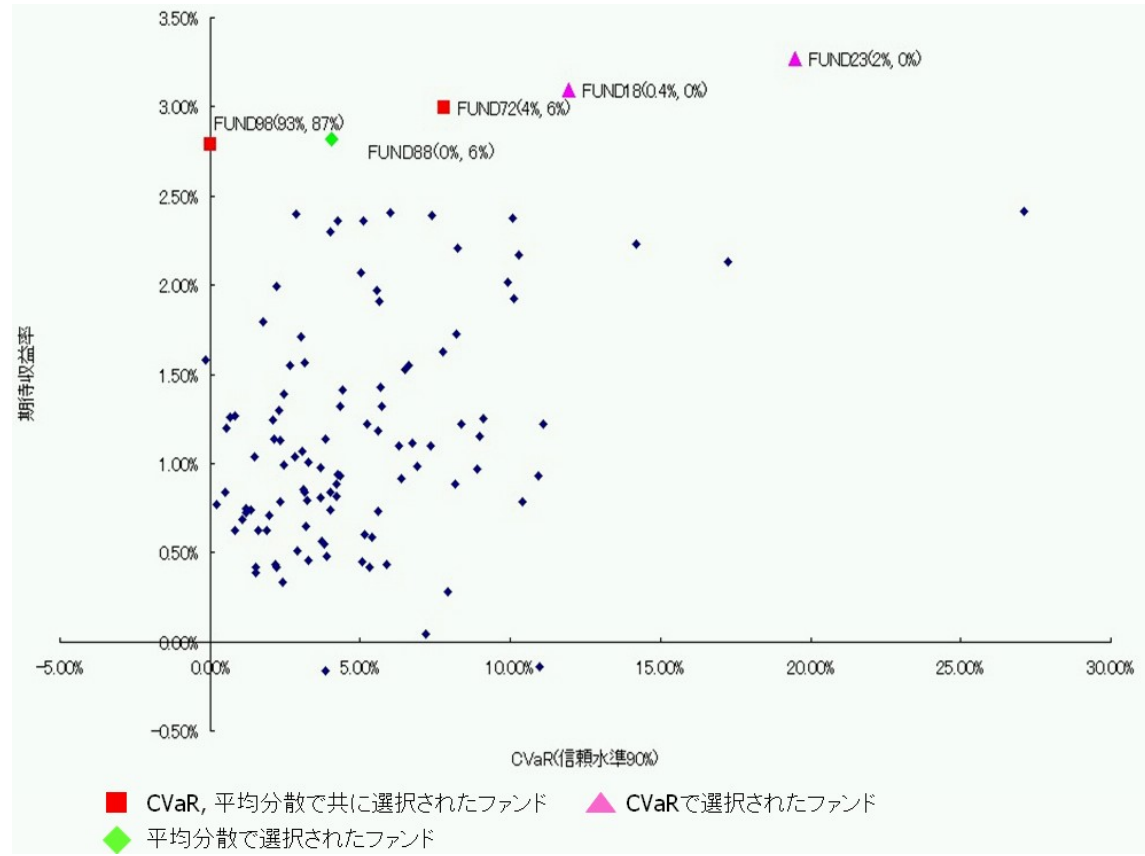

図 6: CVaR, 平均分散アプローチで選択されたファンド（横軸 CVaR）

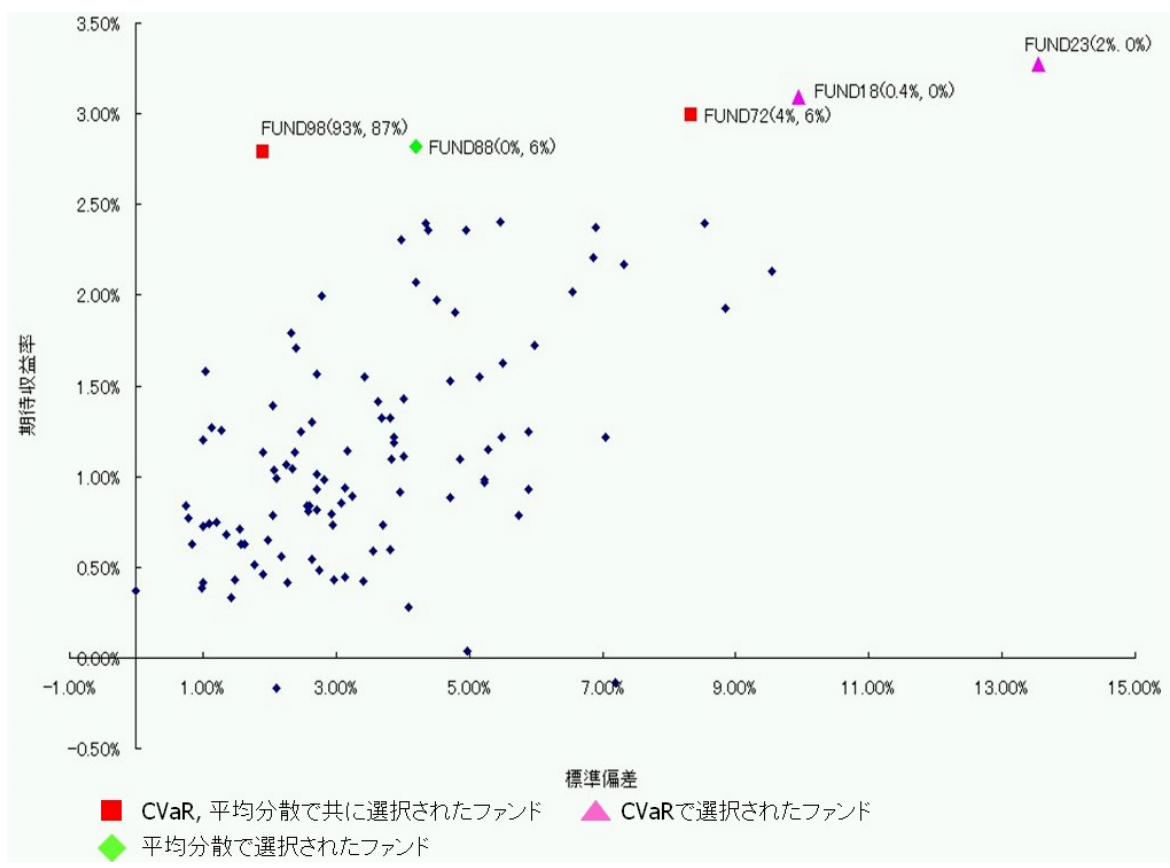

図 7: CVaR, 平均分散アプローチで選択されたファンド (横軸 標準偏差) 


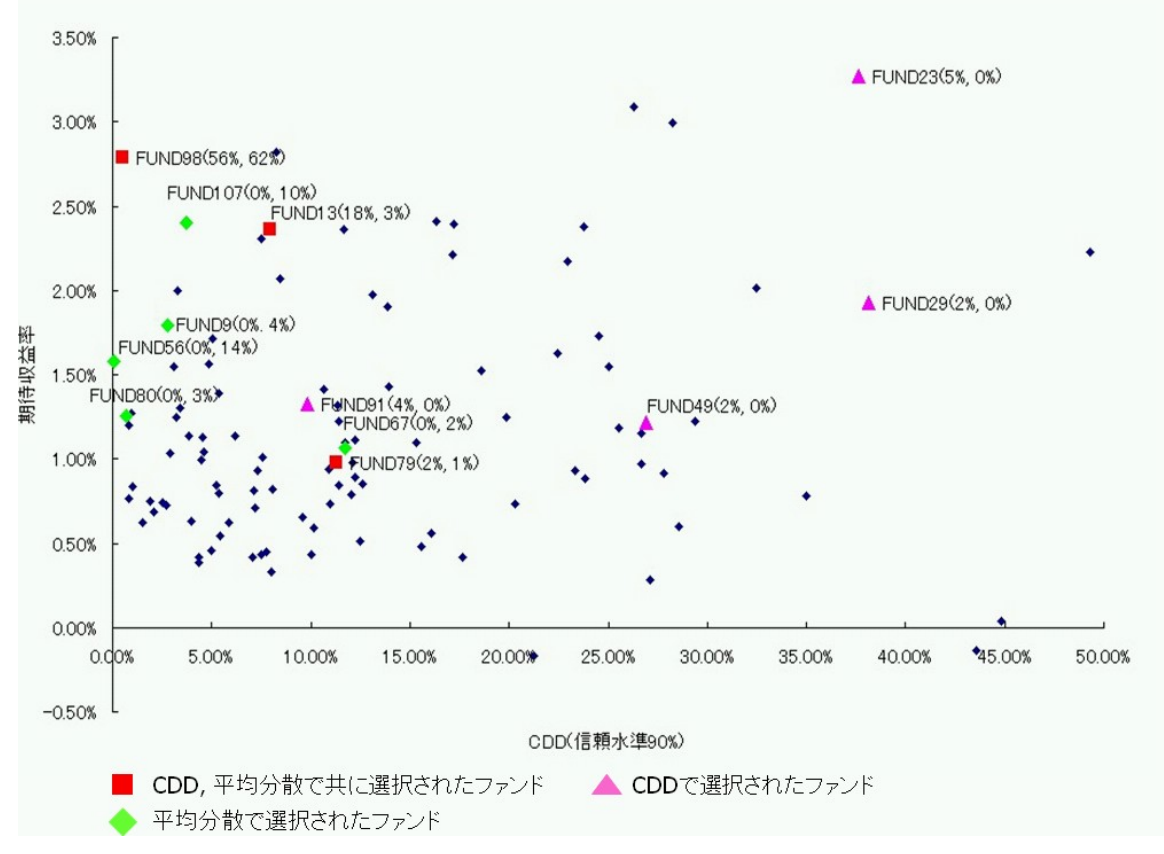

図 8: CDD, 平均分散アプローチで選択されたファンド (横軸 CDD)

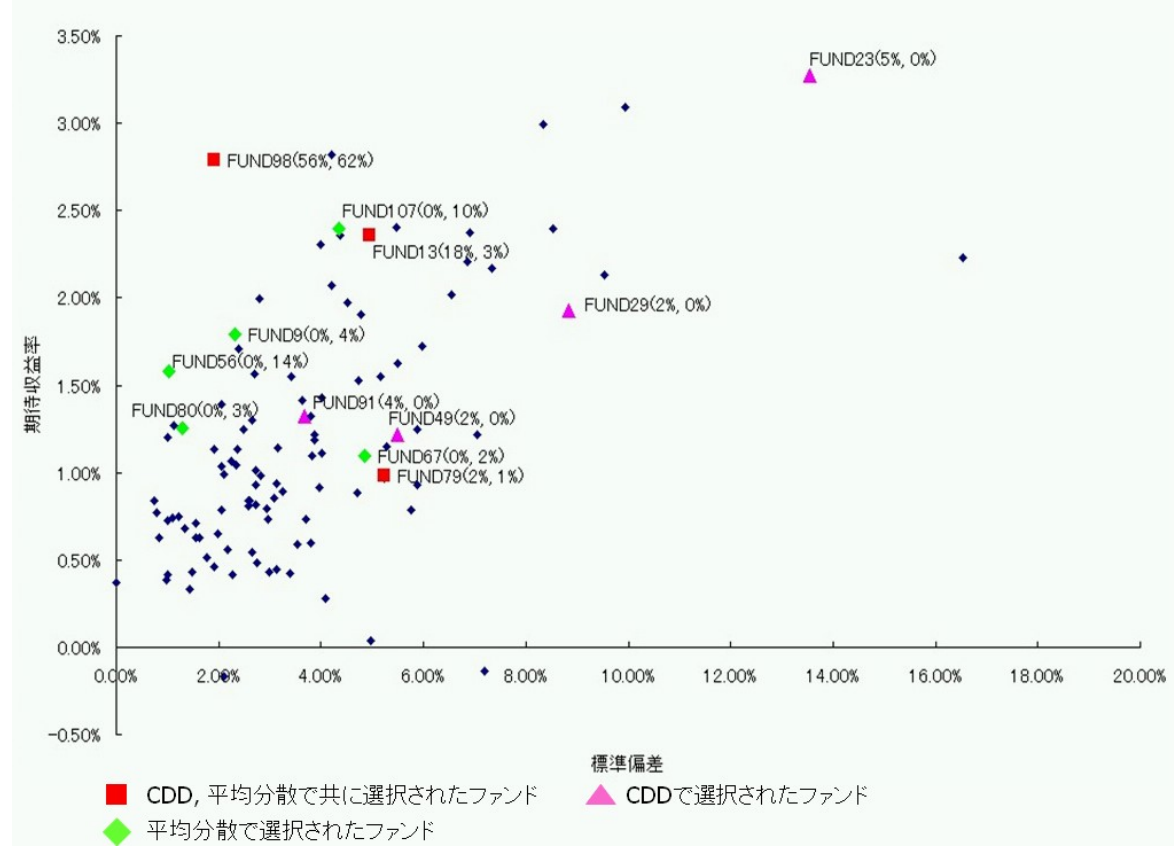

図 9: CDD, 平均分散アプローチで選択されたファンド (横軸 標準偏差) 
に $93 \%$ を配分しているが、平均分散最適ポートフォリオでは $87 \%$ と配分が 減っている。これは、テイル部分をリスクと見なした場合、FUND98 はほぼ 無リスクであるのに対し、標準偏差をリスクと見なした場合、FUND98 がリ スクをもったファンドとなることによる。FUND98 に配分した残りの部分は CVaR 最適ポートフォリオでは FUND98 が損失を被っている時に利益をあげ ている期待収益率の高いファンドに配分する。FUND88 に配分されていない のは FUND98 が損失を被っている時に FUND88 も損失を被っているためで ある。一方、平均分散アプローチでは分散の小さなポートフォリオを構成す るために FUND98 と相関が低く、さらに標準偏差の小さなファンドに配分す る。FUND88 は全体としては FUND98 と相関が低く、FUND18, 23 に比べて 標準偏差が小さいため選択されている。FUND18, 23 が選択されていないのは 標準偏差が大きいためである。次に CDD 最適ポートフォリオと平均分散最適 ポートフオリオの違いを考察する。CDD 最適ポートフォリオの FUND98への 配分が 56 \%と少ないが、この理由は先に述べた。FUND98 に配分した残りの 部分は、FUND98 がドローダウンを被っている時に収益をあげているファン ドに配分する。一方、平均分散アプローチでは FUND98 と相関が低く、さら に標準偏差の小さなファンドに配分する。图 9 を見ると、選択されたファン ドは全て標準偏差が $5 \%$ 以下と小さいことが確認できる。平均分散アプロー チでは FUND98 と FUND56への配分が非常に高くなった。表 7 に主に配分 された FUND98 と FUND56 のリスク指標、また今回利用したファンドのリ スク指標の平均を示した。

\begin{tabular}{cccc}
\hline & FUND56 & FUND98 & 平均 \\
\hline (1) 平均月次リターン & $1.58 \%$ & $2.79 \%$ & $1.23 \%$ \\
(2) 平均月次超過リターン & $1.38 \%$ & $2.59 \%$ & $1.03 \%$ \\
(3) 月次標準偏差 & $1.03 \%$ & $1.91 \%$ & $3.94 \%$ \\
(2)/(3) & 1.34 & 1.36 & 0.32 \\
(4)CVaR(信頼水準 $90 \%)$ & $-0.14 \%$ & $0.01 \%$ & $5.16 \%$ \\
(5)CDD(信頼水準 $90 \%)$ & $0.03 \%$ & $0.51 \%$ & $14.89 \%$ \\
\hline
\end{tabular}

表 7: FUND56, 98 のリスク指標と利用したファンドのリスク指標の平均

FUND98 と FUND56 は標準偏差が小さいだけでなく CVaR, CDD も非常に 小さい。平均分散最適ポートフォリオの CVaR, CDD が非常に小さいのはこ のためである。

\section{3 out-of-sample $の$ 結果}

ここでは $2.2 て ゙$ 紹介した各手法で運用した時の違いを out-of-sample の結果 で検証する。まず 2001 年 1 月から 12 月の月次リターンを in-sample として 


\begin{tabular}{cccccccc}
\hline リスク許容度 & $0.10 \%$ & $0.50 \%$ & $1.00 \%$ & $2.00 \%$ & $3.00 \%$ & $4.00 \%$ & $5.00 \%$ \\
\hline 年率リターン & $23.40 \%$ & $21.92 \%$ & $20.43 \%$ & $17.49 \%$ & $13.93 \%$ & $10.67 \%$ & $7.36 \%$ \\
標準偏差 & $4.87 \%$ & $4.72 \%$ & $4.63 \%$ & $4.59 \%$ & $4.91 \%$ & $5.34 \%$ & $5.87 \%$ \\
シャープレシオ & 4.31 & 4.13 & 3.90 & 3.29 & 2.35 & 1.55 & 0.85 \\
最大ドローダウン & $1.68 \%$ & $1.54 \%$ & $1.42 \%$ & $2.02 \%$ & $2.98 \%$ & $3.76 \%$ & $4.63 \%$ \\
$\mathrm{CVaR}($ 信頼水準 $90 \%)$ & $1.22 \%$ & $1.18 \%$ & $1.11 \%$ & $1.19 \%$ & $1.41 \%$ & $1.79 \%$ & $2.20 \%$ \\
$\mathrm{CDD}($ 信頼水準 $90 \%)$ & $1.43 \%$ & $1.41 \%$ & $1.29 \%$ & $1.63 \%$ & $2.07 \%$ & $2.55 \%$ & $3.73 \%$ \\
\hline
\end{tabular}

表 8: CVaR(信頼水準 90\%) 最適ポートフォリオの 2004-2005 のパフォーマンス

2002 年 1 月のポートフォリオを構築し、次に 2001 年 1 月から 2002 年 1 月の 月次リターンを in-sample として 2002 年 2 月のポートフォリオを構筑する。 以下同樣に、過去の月次リターンのデータを全て in-sample として次の月の ポートフォリオの最適化を行う。

out-of-sample として 2002 年 1 月から 2005 年 12 月まで各手法で運用した 時の資産の推移を図 10-12 に示した。CVaR, CDD 最適ポートフォリオの資 産の推移を見ると、初めの 1 年間はドローダウンを被って収益が伸びていな いことが見て取れる。图 13 にリスク許容度 $0.1 \%$ の CVaR 最適ポートフォリ オで運用した場合の配分の推移を示した。

$\mathrm{CVaR}$ 最適ポートフォリオの配分の推移を見ると、2002 年の 1 月から 3 月 はFUND13 に高い割合て配分している。これは FUND13 が 2001 年に大きな 損失を被らずに高い収益をあげていることによる。FUND13 が 2002 年 3 月 4 月に連続して損失を被ったため、5 月には配分を FUND88 に大きくシフト している。しかし、5 月には FUND13 が大きな収益をあげたため、6 月には また FUND13 に大きくシフトし、損失を被っている。このようにこれらの手 法はサンプルパスアプローチであるためサンプル数が少ない場合はある月に 大きな収益をあげたファンドに次の月から多く配分し、損失を出した場合は 次の月には配分を引き抜くという性質がある。CDD 最適ポートフォリオが初 めの 1 年間にドローダウンを被っているのも全く同じ原因である。また、信 頼水準を $90 \%$ としているため、例えば 20 ケ分のサンプル数しかない場合 はテイルリスクとして参照される月は 2 ケのみである。したがって、サン プル数が少ない場合は CVaR, CDD の信頼度は非常に低い。このような理由 から CVaR, CDD 最適ポートフォリオはサンプル数の少ない初めの 1 年程は 配分の変化が非常に大きくなっている。以上のことから、上で紹介した手法 はサンプル数が少ない場合は信頼性が低いといえる。3 年の in-sample のデー タが確保できる 2004 年から 2005 年の out-of-sample の各手法でのパフォーマ ンスのリスク指標を表 8-10 に示した。

シャープレシオから判断すると、リスク許容度 $0.1 \%$ の CDD 最適ポートフォ リオが最も良いパフォーマンスをしている。さらに年率リターンも $24.04 \%$ と 一番高い。CVaR, CDD も非常に低く、低リスクで高リターンを得ることがで 


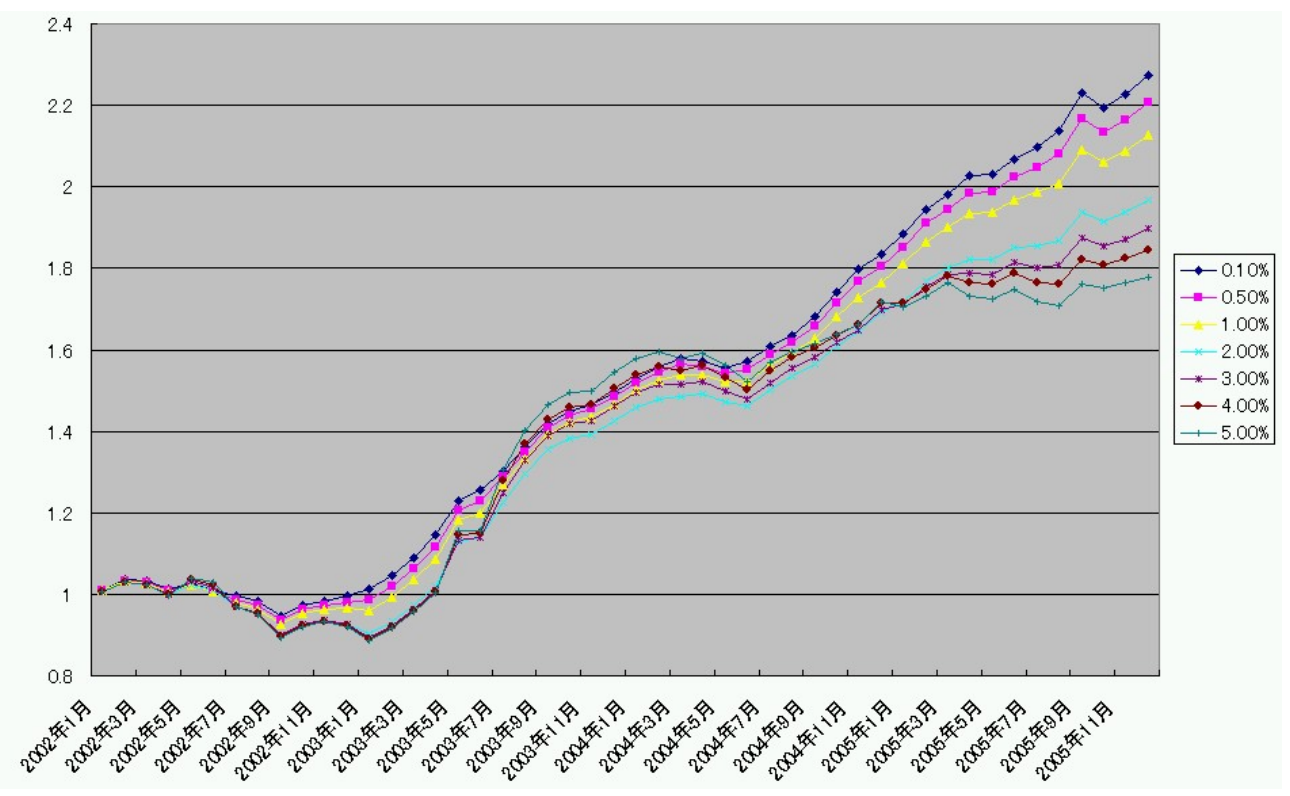

図 10: CVaR 最適ポートフォリオで運用した場合の資産の推移

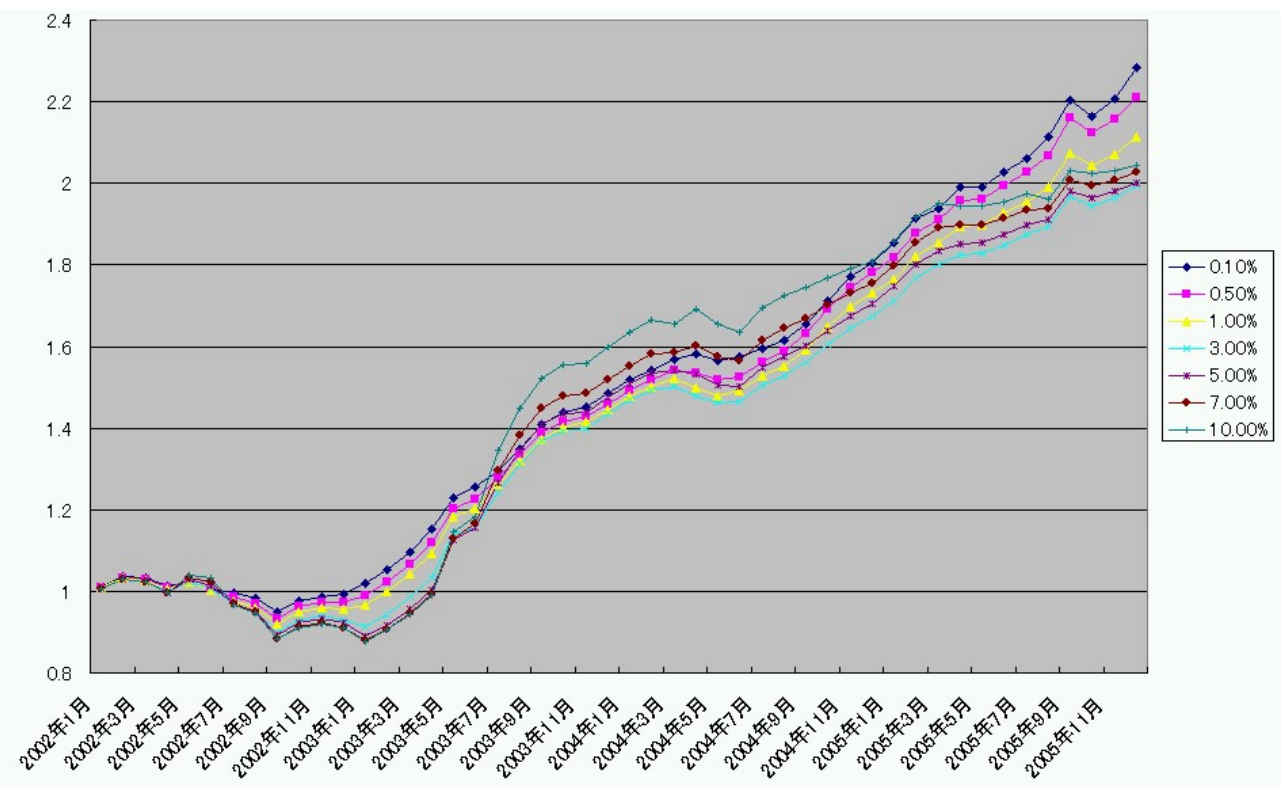

図 11: CDD 最適ポートフォリオで運用した場合の資産の推移 


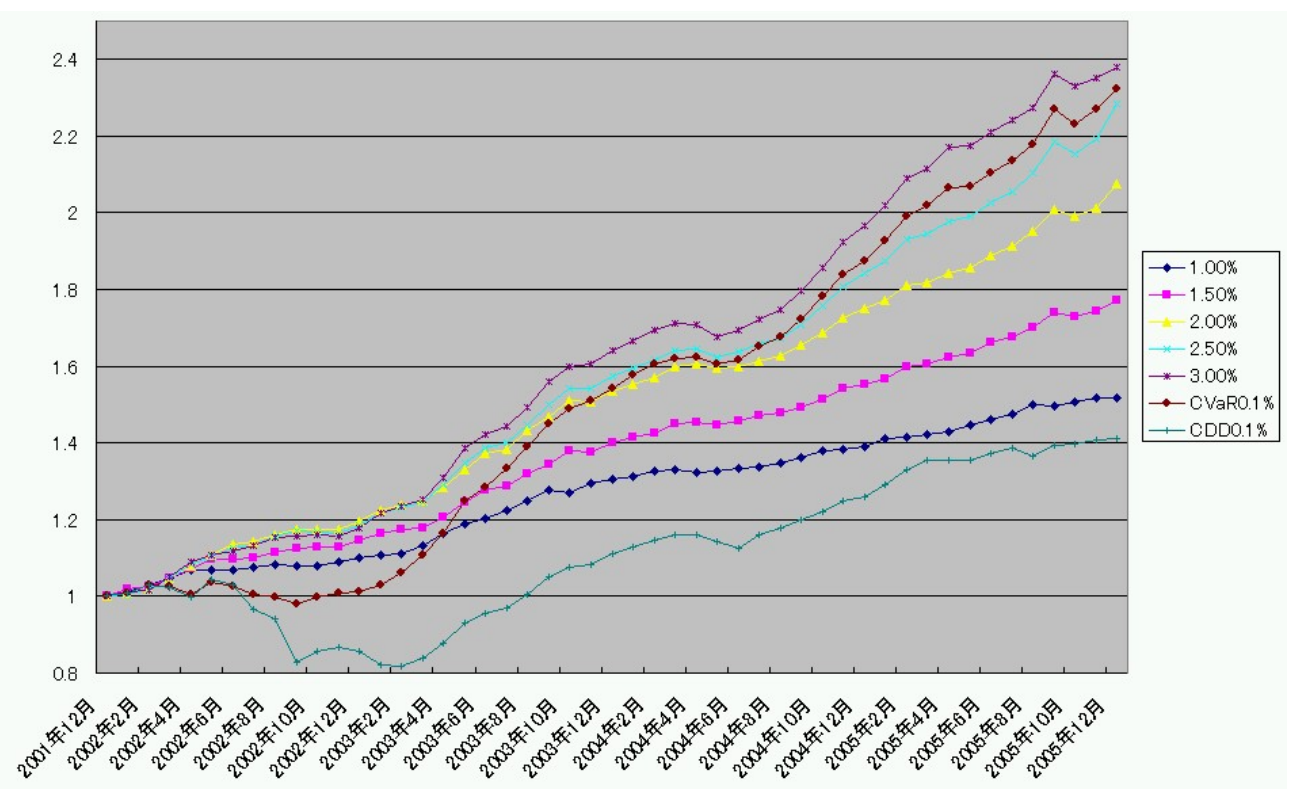

図 12: 平均分散最適ポートフォリオで運用した場合の資産の推移

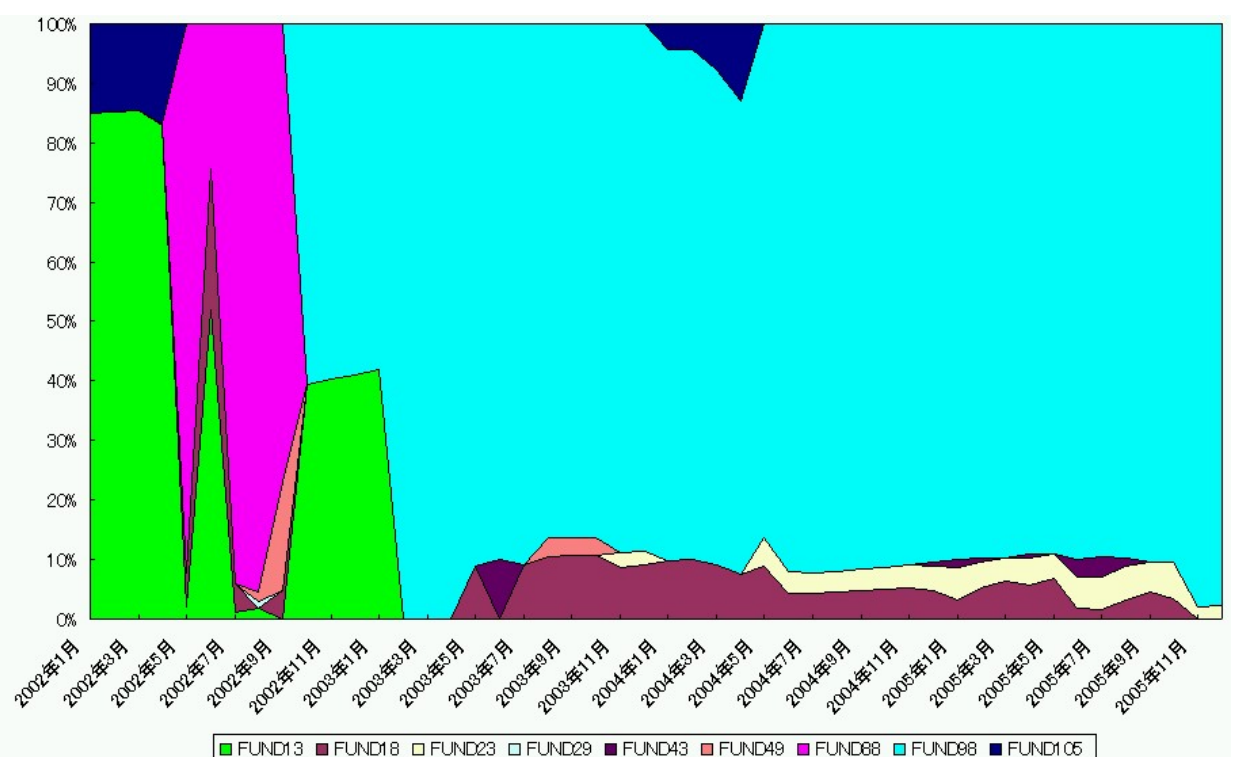

図 13: CVaR 最適ポートフォリオ (リスク許容度 $0.1 \%$ ) で運用した場合の配 分の推移 


\begin{tabular}{cccccccc}
\hline リスク許容度 & $0.10 \%$ & $0.50 \%$ & $1.00 \%$ & $3.00 \%$ & $5.00 \%$ & $7.00 \%$ & $10.00 \%$ \\
\hline 年率リターン & $24.04 \%$ & $23.12 \%$ & $20.98 \%$ & $17.81 \%$ & $16.49 \%$ & $15.50 \%$ & $13.10 \%$ \\
標準偏差 & $4.94 \%$ & $4.89 \%$ & $5.03 \%$ & $4.64 \%$ & $4.52 \%$ & $4.46 \%$ & $5.15 \%$ \\
シャープレシオ & 4.38 & 4.23 & 3.69 & 3.32 & 3.11 & 2.94 & 2.08 \\
最大ドローダウン & $1.80 \%$ & $1.65 \%$ & $2.87 \%$ & $2.67 \%$ & $2.50 \%$ & $2.42 \%$ & $3.29 \%$ \\
$\mathrm{CVaR}($ 信頼水準 $90 \%)$ & $1.14 \%$ & $1.23 \%$ & $1.47 \%$ & $1.30 \%$ & $1.16 \%$ & $1.11 \%$ & $1.49 \%$ \\
$\mathrm{CDD}($ 信頼水準 $90 \%)$ & $1.19 \%$ & $1.47 \%$ & $2.30 \%$ & $2.39 \%$ & $2.14 \%$ & $1.83 \%$ & $2.33 \%$ \\
\hline
\end{tabular}

表 9: CDD(信頼水準 90\%) 最適ポートフォリオの 2004-2005 のパフォーマンス

\begin{tabular}{cccccccc}
\hline 期待収益率 & $1.00 \%$ & $1.50 \%$ & $2.00 \%$ & $2.50 \%$ & $3.00 \%$ & CVaR0.1 \% & CDD0.1 \% \\
\hline 年率リターン & $7.90 \%$ & $12.55 \%$ & $16.30 \%$ & $20.48 \%$ & $20.42 \%$ & $22.78 \%$ & $12.82 \%$ \\
標準偏差 & $1.90 \%$ & $2.42 \%$ & $3.33 \%$ & $4.50 \%$ & $4.93 \%$ & $4.83 \%$ & $4.45 \%$ \\
シャーブレシオ & 2.90 & 4.20 & 4.17 & 4.02 & 3.65 & 4.22 & 2.34 \\
最大ドローダウン & $0.62 \%$ & $0.61 \%$ & $0.88 \%$ & $1.35 \%$ & $2.05 \%$ & $1.68 \%$ & $3.04 \%$ \\
$\mathrm{CVaR}($ 信頼水準 $90 \%)$ & $0.37 \%$ & $0.41 \%$ & $0.64 \%$ & $1.04 \%$ & $1.38 \%$ & $1.20 \%$ & $1.45 \%$ \\
$\mathrm{CDD}($ 信頼水準 $90 \%)$ & $0.41 \%$ & $0.46 \%$ & $0.77 \%$ & $1.12 \%$ & $1.60 \%$ & $1.30 \%$ & $2.21 \%$ \\
\hline
\end{tabular}

表 10: 平均分散最適ポートフォリオの 2004-2005 のパフォーマンス

きている。またリスク許容度 $0.1 \%$ の CVaR 最適ポートフォリオもこれと同 じ位良いパフォーマンスをしている。リスク許容度を大きくしていくにつれ、 CVaR, CDD 最適ポートフォリオ共にリスクが大きいことが見てとれる。これ は、リスク許容度が小さ時には FUND98 に非常に高い割合で配分している ことによる。先に述べたように FUND98 は非常にリスクが小さい一方で高い 収益をあげている。このため、リスク許容度を小さくすればするほど FUND98 の配分か増え、結果的に安定してリターンをあげることができている。リス ク許容度が大きい場合の方が小さい場合より期待リターンが高くなるため実 現リターンも大きくなることが予想されるが、今回は逆の結果となった。こ れは 2001 年からのデータを in-sample とした一方で、out-of-sample の結果を 2004 年から 2005 年のパフォーマンスで評価したことによる。FUND98 より 期待収益率が高く、リスク許容度を大きくすることによって配分が多くなっ たファンドは 2003 年以前に非常に高い収益をあげているが、2004 年以降は 高い収益をあげることができなかった。

平均分散アプローチで CVaR, CDD 最適ポートフォリオと同じ位の高いリ ターンを目指弚うとした場合、リスク許容度 $0.1 \%$ の CVaR 最適ポートフォリ 才と同じ期待収益率をターゲットリターンとした時は FUND98 に多く配分す ることにより非常に良いパフォーマンスとなっているが、リスク許容度 $0.1 \%$ の CDD 最適ポートフォリオと同じ期待収益率をターゲットリターンとした 時とターゲットリターン $3.00 \%$ の時は、シャープレシオは小さい。このよう 
に高い収益率を目指した場合平均分散アプローチは非常に不安定になる。ま た、この3つの場合全てにおいて平均分散最適ポートフォリオの各リスク指 標はリスク許容度 $0.1 \%$ の CVaR, CDD 最適ポートフォリオの光れを下回って いる。このことから、高いリターンを目指す場合は平均分散アプローチより CVaR, CDD 最適化の方が適した手法であるといえる。しかし、高いリター ンを目指すのではなく、安定して収益をあげるようなポートフォリオを目指 す場合、例えばターゲットリターンが $1.5 \%$ の時は、年率リターンが $12.55 \%$ でシャープレシオが 4.20 と非常に安定して収益をあげられていることが分か る。さらに、CVaRやドローダウンも非常に小さく抑えられている。このよ うに安定して収益をあげるようなポートフォリオを目指す場合は平均分散ア プローチは依然有力な手法である。

一つのファンドに高い割合で配分すると光のファンドが大きく損失を出し た時には我々が構築したポートフォリオも大きな損失を被る。弚のようなリ スクは標準偏差や CVaR などの数字には表れない。fund of funds を運用する 際には、光のようなリスクの軽減か期待されるため、非常に良いパフォーマ ンスをしているファンドが存在する場合においても一つのファンドに集中的 に配分することは投資家の要望に反する場合がある。数字に表れないリスク を軽減してもポートフォリオのパフォーマンスが落ちないのであれば、一つ のファンドに高い割合て配分するのは避けた方が良い。ここではシングルファ ンドへの配分に資産の最大 $15 \%$ という制約を加え、上と同樣の最適化を行 い、表 11-13 に2004 年から 2005 年の out-of-sample のパフォーマンスのリス ク指標を示した。

\begin{tabular}{cccccccc}
\hline リスク許容度 & $0.10 \%$ & $0.50 \%$ & $1.00 \%$ & $2.00 \%$ & $3.00 \%$ & $4.00 \%$ & $5.00 \%$ \\
\hline 年率リターン & $15.42 \%$ & $16.30 \%$ & $15.09 \%$ & $13.97 \%$ & $12.66 \%$ & $8.76 \%$ & $8.45 \%$ \\
標準偏差 & $6.39 \%$ & $7.18 \%$ & $7.11 \%$ & $7.19 \%$ & $6.73 \%$ & $7.28 \%$ & $7.95 \%$ \\
シャープレシオ & 2.04 & 1.94 & 1.79 & 1.61 & 1.52 & 0.87 & 0.76 \\
最大ドローダウン & $5.16 \%$ & $6.33 \%$ & $5.93 \%$ & $5.74 \%$ & $4.49 \%$ & $5.00 \%$ & $6.18 \%$ \\
$\mathrm{CVaR}($ 信頼水準 $90 \%)$ & $2.16 \%$ & $2.66 \%$ & $2.56 \%$ & $2.36 \%$ & $2.45 \%$ & $2.84 \%$ & $2.89 \%$ \\
$\mathrm{CDD}($ 信頼水準 $90 \%)$ & $5.06 \%$ & $6.10 \%$ & $5.64 \%$ & $5.14 \%$ & $4.14 \%$ & $4.74 \%$ & $5.55 \%$ \\
\hline
\end{tabular}

表 11: 15 \%制約つき CVaR(信頼係数 90\%) 最適ポートフォリオの 2004-2005 のパフォーマンス

15\%の制約を加えた場合と加えない場合のリスク指標を比べると、全ての ケースにおいて $15 \%$ の制約を加えない方が良いパフォーマンスをしているこ とが分かる。15\% の制約を加えることにより、リターンが功り、各リスク 指標が大きくなることが確認された。

本稿で利用したヘッジファンドは 2001 年から 2005 年までの月次リターン が取得可能なものであったため、サバイバーシップ・バイアスがかかってい ることには注意する必要がある。つまり、今回利用したへッジファンドは少 


\begin{tabular}{cccccccc}
\hline リスク許容度 & $0.10 \%$ & $0.50 \%$ & $1.00 \%$ & $3.00 \%$ & $5.00 \%$ & $7.00 \%$ & $10.00 \%$ \\
\hline 年率リターン & $13.58 \%$ & $14.83 \%$ & $13.20 \%$ & $14.52 \%$ & $12.18 \%$ & $10.27 \%$ & $7.48 \%$ \\
標準偏差 & $5.88 \%$ & $6.91 \%$ & $7.74 \%$ & $6.75 \%$ & $6.91 \%$ & $7.14 \%$ & $8.29 \%$ \\
シャープレシオ & 1.90 & 1.80 & 1.40 & 1.80 & 1.42 & 1.10 & 0.61 \\
最大ドローダウン & $5.27 \%$ & $6.50 \%$ & $7.77 \%$ & $4.73 \%$ & $4.55 \%$ & $4.07 \%$ & $8.27 \%$ \\
$\mathrm{CVaR}($ 信頼水準 $90 \%)$ & $2.16 \%$ & $2.66 \%$ & $3.25 \%$ & $2.24 \%$ & $2.75 \%$ & $2.59 \%$ & $3.10 \%$ \\
$\mathrm{CDD}($ 信頼水準 $90 \%)$ & $5.20 \%$ & $6.47 \%$ & $7.75 \%$ & $4.65 \%$ & $4.21 \%$ & $3.88 \%$ & $7.61 \%$ \\
\hline
\end{tabular}

表 12: 15 \%制約つき CDD(信頼係数 90\%) 最適ポートフォリオの 2004-2005

のパフォーマンス

\begin{tabular}{ccccc}
\hline 期待収益率 & $1.50 \%$ & $2.00 \%$ & $2.50 \%$ & $3.00 \%$ \\
\hline 年率リターン & $12.49 \%$ & $14.29 \%$ & $12.79 \%$ & $11.95 \%$ \\
標準偏差 & $2.75 \%$ & $4.07 \%$ & $5.31 \%$ & $5.43 \%$ \\
シャープレシオ & 3.68 & 2.92 & 1.96 & 1.76 \\
最大ドローダウン & $0.85 \%$ & $1.89 \%$ & $4.28 \%$ & $4.01 \%$ \\
$\mathrm{CVaR}($ 信頼水準 $90 \%)$ & $0.52 \%$ & $0.93 \%$ & $1.72 \%$ & $2.07 \%$ \\
$\mathrm{CDD}($ (信頼水準 $90 \%)$ & $0.72 \%$ & $1.74 \%$ & $3.91 \%$ & $3.70 \%$ \\
\hline
\end{tabular}

表 13: 15 \%制約つき平均分散最適ポートフォリオの 2004-2005 のパフォーマ ンス 
なくとも 5 年間存続しているものであるため、パフォーマンスの悪さゆえに 破綻したファンドが含まれていない。このため、非常に危険なファンドに集

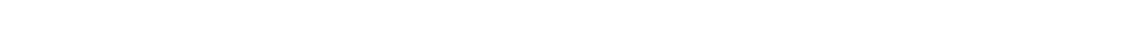
する場合、テイルリスクを考慮しない平均分散アプローチによって最適化を 行った時に色険なファンドが選択される可能性や、集中投資を避けた時のほ うがパフォーマンスが良くなる可能性があることには注意する必要がある。

\section{3 ヘッジファンドのパフォーマンス分析とファンド . オブ・ファンズ運用への適用}

Fung and Hsieh (1997, 1999, 2000a, 200b, 2001, 2002a, 2002b, 2004a, 2004b) や Agarwal and Naik (2004) などの研究によると、ヘッジファンドのリターン も個別株や投資信託と同樣に株価インデックスなどのリスクファクターによっ て説明される場合が多い。ここでヘッジファンドのリターンが投資信託の关 れと大きく異なるのは、ショートやレバレッジの影響に加えてリターンが原 資産に対して非線形に反応する場合があるということである。3.1 でへッジ ファンドのリターンの要因分解を行い、3.2で 2 節のポートフォリオ最適化と 3.1 のヘッジファンドのパフォーマンス分析を統合してファンド・オブ・ファ ンズ運用におけるファンドの選択からリスク管理の一連の流れを示す。

\section{1 ヘッジファンドのパフォーマンス分析}

理論上ではファンドのリターンは式 (11)ようにリスクファクターのリター ンと光のファンドの付加価值 (alpha) に要因分解することが出来る。

$$
r_{i}=\alpha_{i}+\sum_{j=1}^{m} \beta_{i j} f_{j}+\epsilon_{i}
$$

ここで、 $r_{i}$ はファンド $i$ のターンを表し、 $f_{j}$ はリスクファクター $j$ のリター ンを表す。 $\alpha_{i}, \epsilon_{i}$ はリスクファクターでは説明できない部分であり、 $\alpha_{i}$ はファ ンド $i$ の付加価值、 $\epsilon_{i}$ は誤差を表す。この節では 39 のヘッジファンドに対し、 リターンを株価インデックスなどの市場で観測できるリスクファクターのリ ターンを説明変数として回帰分析を行うことにより式(11)ように要因分解を 行う。本稿では、回帰分析を行った結果の切片をアルファと呼ぶことにする。

本稿でリスクファクターとして採用したのは株価インデックスとしてアジ ア各国の代表的な株価インデックスと S\&P500、ダウ欧州株価指数、ボンドイ ンデックスとしてアジア各国と USA の MSCI bond index、各国の対米ドル為 替レート、乥して上で採用した株価インデックスのオプションである。以上の インデックスは Bloomberg のデータを利用した。表 14-16に今回利用したイ ンデックスを示した。日本の株価インデックスはラッセル・野村のスタイルイ 


\begin{tabular}{|c|c|c|c|c|c|}
\hline \multirow[t]{9}{*}{ オーストラリア } & AS25 Index & AS25 S \& P/ASX 100 INDEX & シンガポール & BTSRI Index & BTSRI SING: BUSINESS TIME REGN \\
\hline & AS26 Index & AS26S \& P/ASX 20 INDEX & & SESALL Index & SESALL SINGAPORE ALL INDEX \\
\hline & AS31 Index & AS31 S \& P/ASX 50 INDEX & & STI Index & STI STRAITS TIMES INDEX \\
\hline & AS34 Index & AS34 S \& P/ASX MIDCAP 50 INDEX & & UOBDAQ Index & UOBDAQ SING: UOB SESDAQ INDEX \\
\hline & AS38 Index & AS $38 \mathrm{~S} \&$ P/ASX SMALL ORDS INDEX & 韓国 & KRX100 Index & KRX100 KOREA EXCHANGE 100 INDEX \\
\hline & AS39 Index & AS39 ASX SMALLCAP RESOURCES & & KOSPI Index & KOSPI KOREA COMPOSITE INDEX \\
\hline & AS40 Index & AS40 ASX SMALLCAP INDUSTRIALS & & KOSPI2 Index & KOSPI2 KOREA KOSPI 200 INDEX \\
\hline & AS51 Index & AS51 S \& P/ASX 200 INDEX & & KOSDAQ Index & KOSDAQ KOSDAQ COMPOSITE INDEX \\
\hline & AS52 Index & AS52 S \& P/ASX 300 INDEX & & KOSPI100 Index & KOSPI100 KOREA KOSPI 100 INDEX \\
\hline \multirow[t]{10}{*}{ シンセン } & SZASHR Index & SZASHR CHINA SE SHENZHEN A & & KOSPI50 Index & KOSPI50 KOREA KOSPI 50 INDEX \\
\hline & SZBSHR Index & SZBSHR CHINA SE SHENZHEN B & & KOSPLMKC Index & KOSPLMKC KOSPI LARGE CAP INDEX \\
\hline & SZCOMP Index & SZCOMP CHINA SE SHENZ COMPOSITE & & KOSPMMKC Index & KOSPMMKC KOSPI MID CAP INDEX \\
\hline & SIASA Index & SIASA SSE A-SHARE INDEX & & KOSPSMKC Index & KOSPSMKC KOSPI SMALL CAP INDEX \\
\hline & SIBSB Index & SIBSB SSE B-SHARE INDEX & & KOSTAR Index & KOSTAR KOSDAQ STAR INDEX \\
\hline & SICOM Index & SICOM SSE CONSTITUENT STOCK IX & & KOSDAQ50 Index & KOSDAQ50 KOSDAQ50 INDEX \\
\hline & SHSZ300 Index & SHSZ300 SHSE-SZSE300 INDEX & & KOSD100 Index & KOSD100 KOSDAQ 100 INDEX \\
\hline & FXTID Index & FXTID FTSE/XINHUA CHINA 25 & & KOSDM300 Index & KOSDM300 KOSDAQ MID300 INDEX \\
\hline & XIN3I Index & XIN3I FTSE XINHUA CH A200 INDX & & KOSDSMAL Index & KOSDSMAL KOSDAQ SMALL INDEX \\
\hline & XIN5I Index & XIN5I FTSE XINHUA CH A400 INDX & 台湾 & TWSE Index & TWSE TAIWAN TAIEX INDEX \\
\hline \multirow{6}{*}{ 上海 } & SHASHR Index & SHASHR CHINA SE SHANGHAI A & & TW50 Index & TW50 TSEC TAIWAN 50 INDEX \\
\hline & SHBSHR Index & SHBSHR CHINA SE SHANGHAI B & & TWMC Index & TWMC TSEC MID-CAP 100 INDEX \\
\hline & SHCOMP Index & SHCOMP CHINA SE SHANG COMPOSITE & & TWIT Index & TWIT TSEC TECHNOLOGY INDEX \\
\hline & SSE180 Index & SSE 180 CHINA SE SHANG 180 A SHR & & TWOTCI Index & TWOTCI TAIWAN GRE TAI EXCHANGE \\
\hline & SSE50 Index & SSE50 SHANGHAI SE 50 A-SHR IDX & タイ & SET Index & SET STOCK EXCH OF THAI INDEX \\
\hline & SHSZ300 Index & SHSZ300 SHSE-SZSE300 INDEX & & SET50 Index & SET50 THAI SET 50 INDEX \\
\hline \multirow[t]{7}{*}{ 香港 } & HKX Index & HKX AMEX HONG KONG 30 INDEX & & MAI Index & MAI THAI STOCK EXCHG MAI IX \\
\hline & HSI Index & HSI HANG SENG INDEX & & SET100 Index & $\begin{array}{l}\text { SET100 THAI SET } 100 \text { INDEX } \\
\text { Th }\end{array}$ \\
\hline & HSHKLI Index & HSHKLI HANG SENG HK LARGE CAP & バングラデシュ & DHAKA Index & DHAKA DHAKA STK EXG DHAKA EXCH \\
\hline & HSHKMI Index & HSHKMI HANG SENG HK MID CAP IDX & インド & BSE100 Index & BSE100 BOMBAY STOCK EX 100 IDX \\
\hline & HSHKSI Index & HSHKSI HANG SENG HK SMALL CAP & & BSE200 Index & BSE200 BOMBAY STOCK EX 200 IDX \\
\hline & HKSPLC25 Index & HKSPLC25 S \& P/HKEx LargeCap Index & & SENSEX Index & SENSEX BSE SENSEX 30 INDEX \\
\hline & HKSPGEM Index & HKSPGEM S \& P/HKEx GEM Index & & DOLLEX Index & DOLLEX DOLLEX INDEX DOLLEX IDX \\
\hline \multirow{6}{*}{ ジャカルタ } & JCI Index & JCI JAKARTA COMPOSITE INDEX & & NIFTY Index & NIFTY NSE S \& P CNX NIFTY INDEX \\
\hline & MBX Index & MBX JAKARTA SE MAIN BOARD IX & & DOLL30 Index & DOLL30 DOLLEX INDEX DOLL BSE30 \\
\hline & DBX Index & DBX JAKARTA SE DEVEL BRD IDX & & BSE500 Index & BSE500 BOMBAY STOCK EX 500 IDX \\
\hline & LQ45 Index & LQ45 JAKARTA LQ-45 INDEX & & DEFTY Index & DEFTY NSE S \& P CNX DEFTY INDEX \\
\hline & D300IN Index & D300IN HSBC Dragon INDONESIA & & BSEMDCAP Index & BSEMDCAP BSE MID-CAP INDEX \\
\hline & JAKISL Index & JAKISL JAKARTA ISLAMIC INDEX & & BSESMCAP Index & BSESMCAP BSE SMALL-CAP INDEX \\
\hline スラパヤ & SSXCSPI Index & $\begin{array}{l}\text { SSXCSPI SSX CSPI } \\
\text { SWIC INLA }\end{array}$ & & NIFTYJR Index & NIFTYJR NSE S \& P CNX MIDCAP INDEX \\
\hline \multirow[t]{4}{*}{ マレーシア } & KLSI Index & KLSI KUALA LUMPUR SYARIAH IX & & CNXBANK Index & CNXBANK BANK NIFTY INDEX \\
\hline & KL2ND Index & KL2ND KUALA LUMPUR 2ND BOARD & & CNXMCAP Index & CNXMCAP NSE CNX MIDCAP INDEX \\
\hline & KLCI Index & KLCI KUALA LUMPUR COMP INDEX & & FTY1ID Index & FTY1ID FTSE World India \\
\hline & MCI Index & MCI MESDAQ COMPOSITE INDEX & パキスタ タター & KSE Index & KSE Pakistan All Share \\
\hline \multirow[t]{5}{*}{$\mathrm{NZ}$} & NZSE Index & $\begin{array}{l}\text { NZSE NZX ALL INDEX } \\
\text {. }\end{array}$ & & KSE100 Index & KSE100 PAKISTAN 100 INDEX \\
\hline & NZSEG Index & NZSEG NZX ALL GROSS INDEX & スリランカ & CSEALL Index & CSEALL Sri Lanka All Share \\
\hline & NZSE10 Index & NZSE10 NZX TOP 10 INDEX & & SPX Index & S \& P 500 \\
\hline & NZSEMC Index & NZSEMC NZX MID CAP INDEX & 欧州 & SXXP Index & ダウ欧洲株価指数 \\
\hline & NZSESC Index & NZSESC NZX SMALLCAP INDEX & & & \\
\hline \multirow{3}{*}{ フィリピン } & PASHR Index & PASHR PHILIPPINES ALL SHARE IX & & & \\
\hline & PCOMP Index & PCOMP PHILIPPINES COMPOSITE IX & & & \\
\hline & SME Index & SME PHILIPPINES SM-MED ENTER & & & \\
\hline
\end{tabular}

表 14: 株価インデックス

\begin{tabular}{cc}
\hline MDALTR Index & MSCI Australia TR \\
MDJPTR Index & MSCI Japan TR \\
MDNZTR Index & MSCI New Zealand TR \\
MDUSTR Index & MSCI US Treasury TR \\
MAHKTR Index & MSCI Hong Kong Dollar Swap TR \\
MAIDTR Index & MACI Indonesia Rupiah Swap TR \\
MAPHTR Index & MSCI Phlippines Peso Swap TR \\
MASGTR Index & MSCI Singapore Dollar Swap TR \\
MASKTR Index & MSCI South Korea Won Swap TR \\
MATHTR Index & MSCI Thailand Baht Swap TR \\
MATWTR Index & MSCI Taiwan Dollar Swap TR \\
\hline
\end{tabular}

表 15: ボンドインデックス 


\begin{tabular}{cc}
\hline JPY Curncy & 日本円 \\
EUR Curncy & ユーロ \\
SGD Curncy & シンガポールドル \\
KRW Curncy & 韓国ウォン \\
TWD Curncy & 台湾ドル \\
HKD Curncy & 香港ドル \\
THB Curncy & タイバーツ \\
MYR Curncy & マレーシアリンギ \\
IDR Curncy & インドネシアルピア \\
AUD Curncy & オーストラリアドル \\
NZD Curncy & ニュージーランドドル \\
INR Curncy & インドルピー \\
PHP Curncy & フィリピンペソ \\
CNY Curncy & 中国人民元 \\
\hline
\end{tabular}

表 16: 対米ドル為替レート

ンデックスを用い、さらにリスクファクターとしてサイズ・ファクター (small minus big, SMB) と book-to-market ファクター (high minus low, HML) を構成 する。発展途上諸国では大型株、小型株、あるいはバリュー株、グロース株の 分類が困難で日本のようにスタイルインデックスが存在しない国も多い。し たがってこれらの国においては、サイズ・ファクターや book-to-market ファ クターを構成することができないため、ファクターとしては株価インデック ス谷のものしか採用できない。MSCI bond index に関しては各国のボンドイン デックス谷のもののリターンと各国と US treasury のスプレッドをファクター として採用し、為替に関しては各国の対米ドル為替レートのリターンをファ クターとする。fixed incomeや distressed debt などの戦略をとるファンドに対 してはクレジットスプレッドのインデックスがリスクファクターとして期待 されるが、データの取得が困難であるため、本稿においては株価インデック スで代用する。株価インデックスのオプションは ATM,OTM のプットとコー ルをブラック・ショールズ式で計算したものを利用する。ここではボラティ リティはヒストリカルボラティリティとし、OTM の行使価格はプットオプ ションに対してはスポット価格の 99\%、コールオプションに対してはスポッ 卜価格の $101 \%$ とする。ここでオプションのリターンとは次のようなトレー ディングによって得られるリターンを表す。例えば、2001 年 4 月のリターン とは 2001 年 3 月末に 5 月満期のオプションを購入し、4 月末に 5 月満期のオ プションを売却して得られるリターンを表す。

Agarwal and Naik(2004) では event drivenや disstresed debt などの戦略をと るヘッジファンドは株価インデックスのリターンに対し、非線形なリターン 
を生む傾向があることが確認された。我々はまずファンドのリターンを株価 インデックス、ボンドインデックス、為替のファクターに要因分解し、リス クファクターに対するファンドのリターンの反応の仕方を考察し、非線形性 が確認されたファンドに対して株価インデックスのオプションをリスクファ クターに加えて再び要因分解を行う。回帰分析は 2001 年 1 月から 2005 年 12 月までの 60 ケ月分の全ての月次リターン、2001 年 1 月から 2003 年 4 月まで の 28 ヶ月分の月次リターン、2003 年 5 月から 2005 年 12 月までの 32 ヶ月分

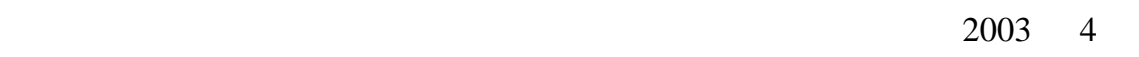
はバブル景気以降で日本の株価が底值を記録した月である。

回帰分析を行った結果を表 17-25に示した。戦略別の特徵と主なリスクファ クターは以下の通りである。

- 戦略 : Distressed Debt

主なファクター : 株価インデックス, $\mathrm{SMB}$, オプション,ボンドインデッ クス

前半ではオプションの有意性が目立つが、後半ではオプションファク ターを持つファンドは少ない。市場が大きく下がった時にさらに大きな 損失を出す傾向があると考えられる。

- 戦略 : Relative Value

主なファクター : 株価インデックス, SMB, HML, オプション, ボンドイ ンデックス

特に前半ではオプションが有意である。全体的に株関連のファクターが 有意であり、ボンドの有意性は小さい。

- 戦略 : Long / Short Equities

主なファクター : 株価インデックス, SMB, HML, オプション

Korea, Greater China, AS/NZ, emerging, Asia-ex Japan を投資対象とする ファンドの説明力は高い。Japan Only を投資対象とするファンドの前半 の説明力は特に低い。各ファンドが市場全体か下がっている時に利益を 出すようなトレーディング戦略を駆使していると考えられる。

- 戦略 : Fixed Income

主なファクター : 株価インデックス, SMB, オプション, ボンドインデッ クス, US-スプレッド

株価インデックスの有意性が高く、クレジット関連の市場に対するエク スポージャーが高いと考えられる。

- 戦略 : Multi Strategy 
主なファクター : 株価インデックス, SMB, オプション, ボンドインデッ クス, US-スプレッド, 為替

ファンドによって有意なファクターが大きく異なる。またファンド毎に も前半と後半でエクスポージャーが大きく異なる。

- 戦略：Macro

主なファクター : 株価インデックス, SMB, ボンドインデックス, US-ス プレッド, 為替

レバレッジを大きくとっていて投資している。市場が大きく動いたとき に、さらに大きな利益や損失を出している。光の一方でオプションファ クターが有意にならず、為替の有意性が目立つ。

- CTA

主なファクター : 株価インデックス, SMB, オプション,ボンドインデッ クス, US-スプレッド, 為替

Macro と同樣にレバレッジを大きくとっていて投資している。市場が大 きく動いたときに、さらに大きな利益や損失を出している。Macro と異 なる点は為替の有意性が少なく、後半でオプションファクターが有意な ファンドがあるということである。また Macro に比べて損益の振れは 小さい。

- 戦略：Event Driven

主なファクター : 株価インデックス, SMB, 為替

株価インデックスが主に有意なファクターであるが、後半で為替が有意 である。

オプションをファクターに加えることにより説明力が特に向上したものは、 Distressed Debt の戦略をとるファンドと日本の株関連の市場にエクスポー ジャーを持つファンドであつた。表 26 に戦略別の説明力を示した。60ケ月分 の全ての月次リターンに対して行った場合は説明力は全体的に低かったが、前 半と後半に分けた場合説明力は向上している。戦略別で特に Macro, CTA が 説明力が大きく向上していることが分かる。また Long / Short Equities の改善 度は小さい。表 27 に地域別の説明力を示した。Global や Asia inclu Japan の ように投資対象地域を広くとっているファンドの説明力が前半と後半に分け ることにより大きく向上した。また、特に前半でJapan Only の説明力が低い が、のことから各ファンドが市場全体か下がっている時に利益を出すよう なトレーディンク戦略を駆使していると考えられる。一方、 Emerging Merkets や Asia ex-Japan などのような投資対象地域で差別化をはかっているファンド は線形のファクターで高い説明力を実現することができた。 
各ファンドの持つリスクファクターを見ると前半と後半でエクスポージャー が大きく変わっているファンドが多く見受けられる。このことから各ファンド は状況に応じて投資対象地域やスタイルを切り替えていることが分かる。し たがって各時点でファンドの持つリスクを把握するためには非線形性を表す より適切なファクターを説明変数に加えるか、ファンドのエクスポージャー を動的に捉える必要がある。

\section{2 ファンド・オブ・ファンズ運用への適用}

最後に、ポートフォリオ最適化とパフォーマンス分析を統合して、我々の 手法の実務への適用を示す。我々は 2 節の最適化によって構成されたポート フォリオの 2005 年のリターンをリスクファクターとファンドのアルファに よって再現することを試みる。ここでは、最もシャープレシオの高いリスク 許容度 $0.1 \%$ の CDD 最適ポートフォリオに対して分析を行った。まず、過去 2 年のデータを使って選択されたファンドのリターンの要因分解を行い、ファ クターへのエクスポージャーとファンドのアルファを調べる。この際、回帰分 析の説明変数と弚の係数は in-sample のデータを 1,2 個取り替えても大きく変 わらないと考えられるため、3ヶ月ごとに回帰分析をやり直して、エクスポー ジャーの変化を捉えることにする。四半期毎のエクスポージャーを表 28-31 に示した。光して、ヘッジファンドのポートフォリオをリスクファクターと ファンドのアルファのポートフォリオと見なし、これらからポートフォリオ のリターンを再現する。

図 14 にCDD 最適ポートフォリオで運用した場合の資産の推移と(ファク ターリターン)+(アルファ)の資産の推移を示した。

5 月と 10 月の損益をリスクファクターによって再現できていないことが見 てとれるが、他の10ケ月に関しては精度良く再現できている。図 19 に配分の 推移を示した。10 月までは FUND98 がポートフォリオの $90 \%$ 前後を占めて いることが分かる。図 15-18 に FUND98 を始め、配分比率が高い上位 4 ファ ンドのリターンと光の(ファクターリターン)+(アルファ)の推移を示した。

图 15 を見ると FUND98 の 5 月と 10 月の損益をリスクファクターで再現でき ていないことが確認され、このことが最適ポートフォリオのリターンを 2 ヶ 月予測できなかった要因であると考えられる。

リスクファクターの動きは日次で観測することができるため、個別ファン ドの運用状況がレポートされていない場合においても各ファンド、またファン ド・オブ・ファンズのパフォーマンスを予測するすることが出来る。さらに、 リスクファクターが取引されている場合にはリスクをへッジすることが可能 である。ポートフォリオ最適化とパフォーマンス分析への我々のアプローチ はファンド・オブ・ファンズ運用におけるポートフォリオ構築とリスク管理 に有用であろう。さらなる要因分解の精度向上のためには、より適切なリス 


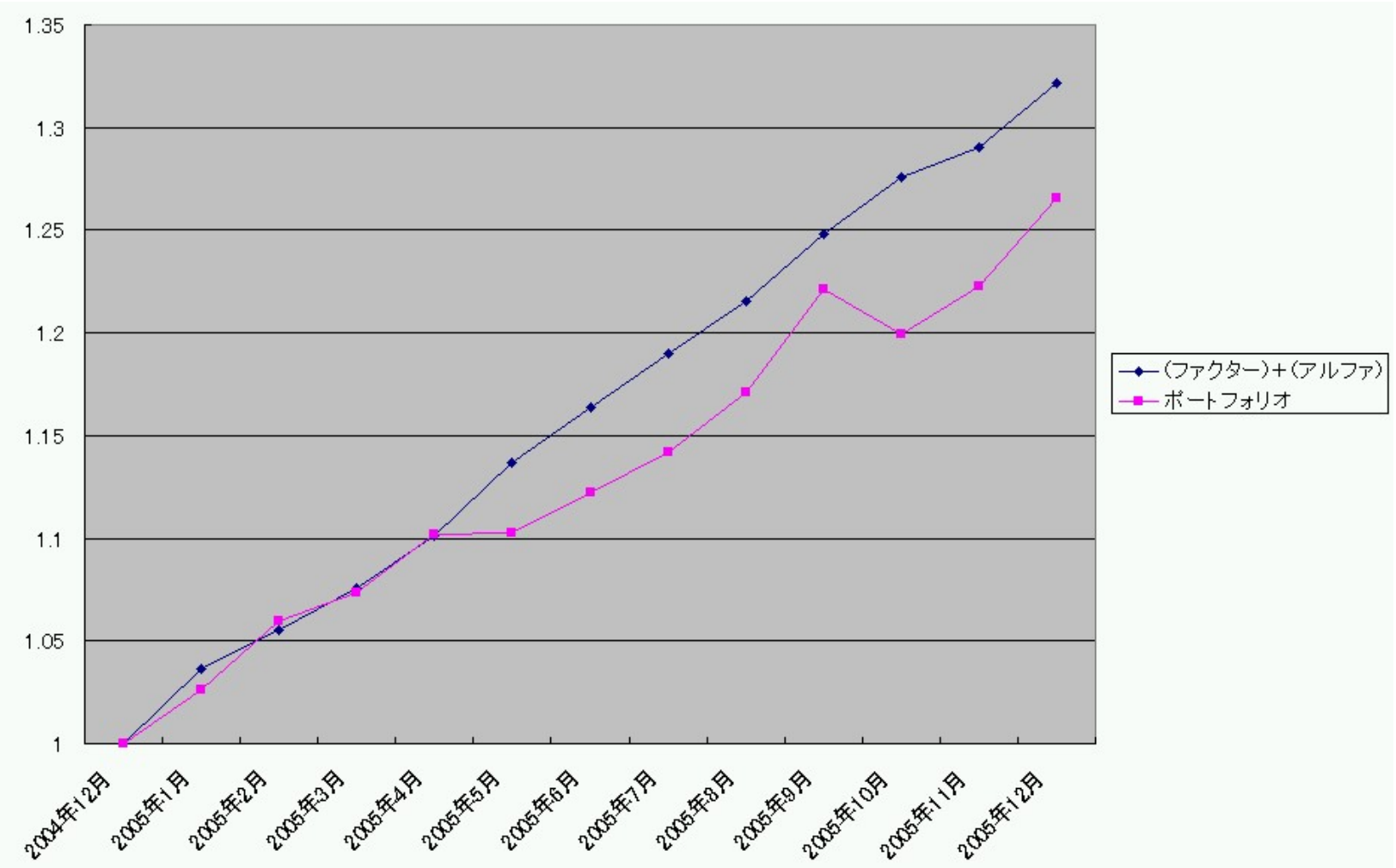

図 14: CDD 最適ポートフォリオ (リスク許容度 $0.1 \%$ ) と (ファクターリター ン + + (アルファ $)$ の資産の推移 


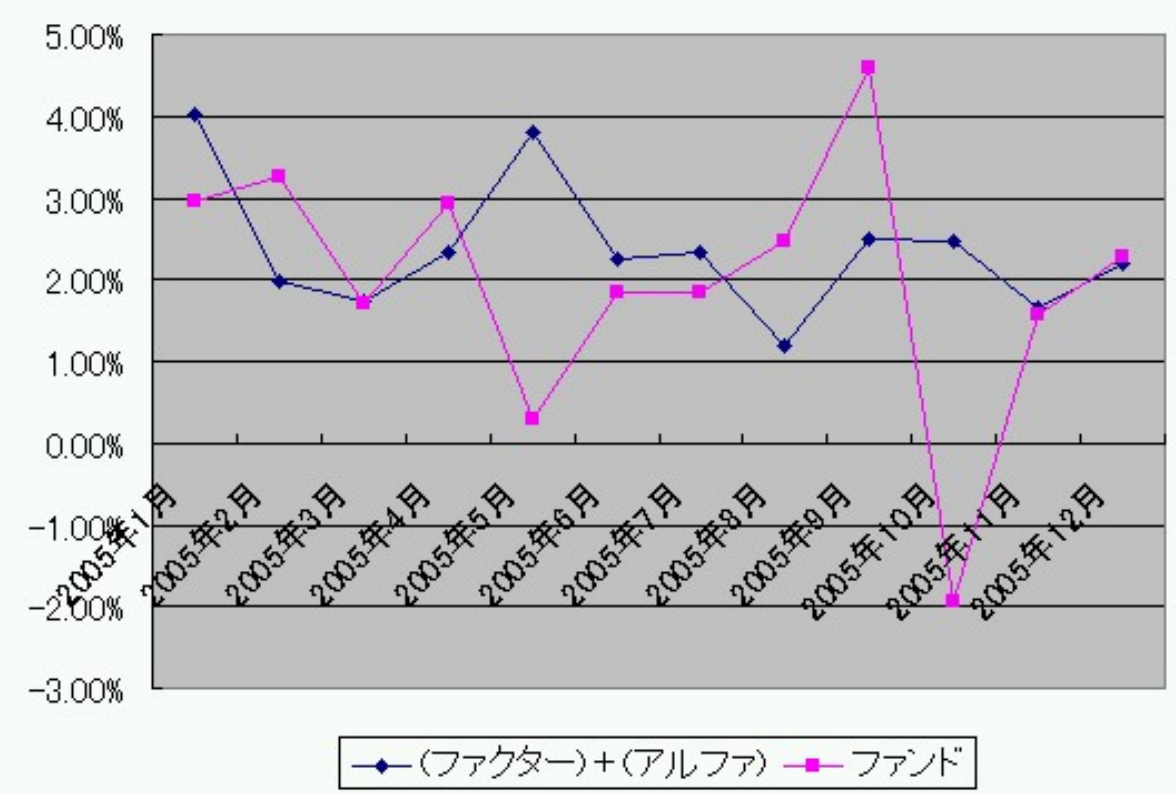

図 15: FUND98(Event Driven) のリターンと (ファクターリターン) + (アル ファ)

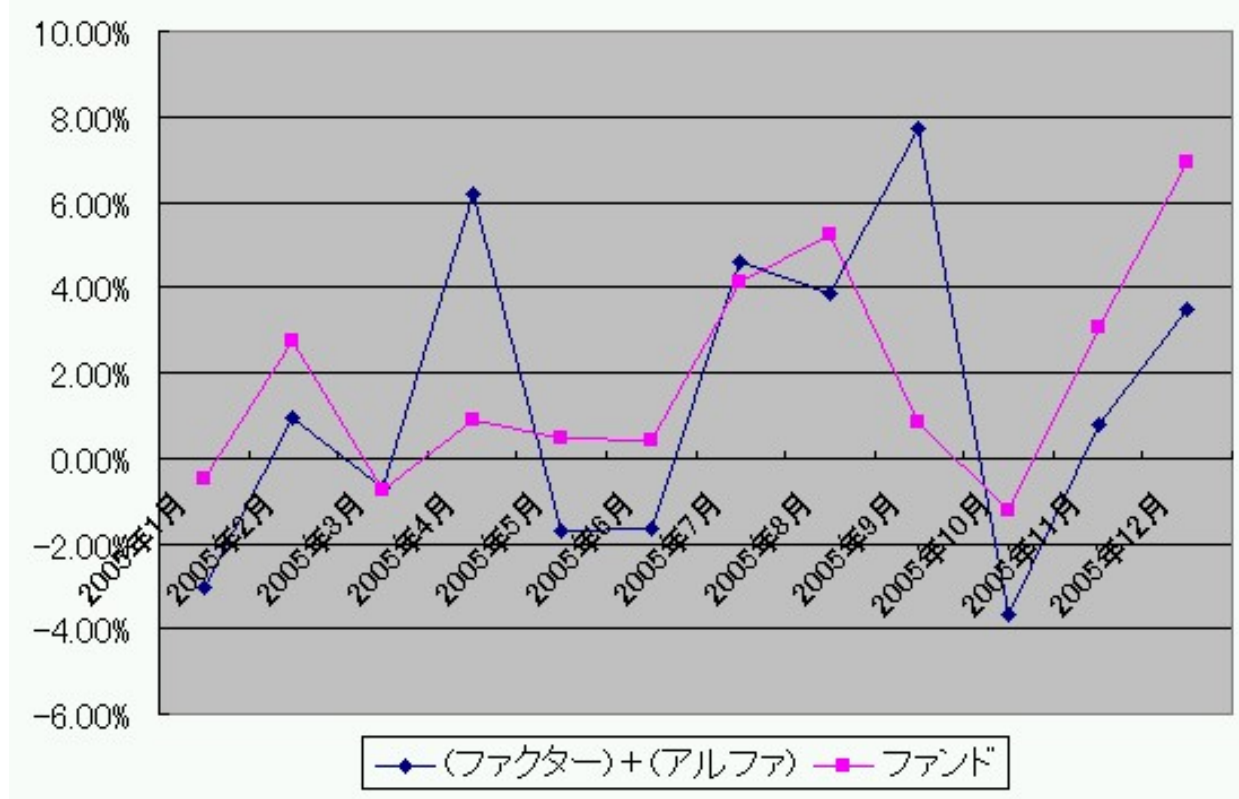

図 16: FUND13 (Multi-Strategy) のリターンと (ファクターリターン) + (アル ファ) 


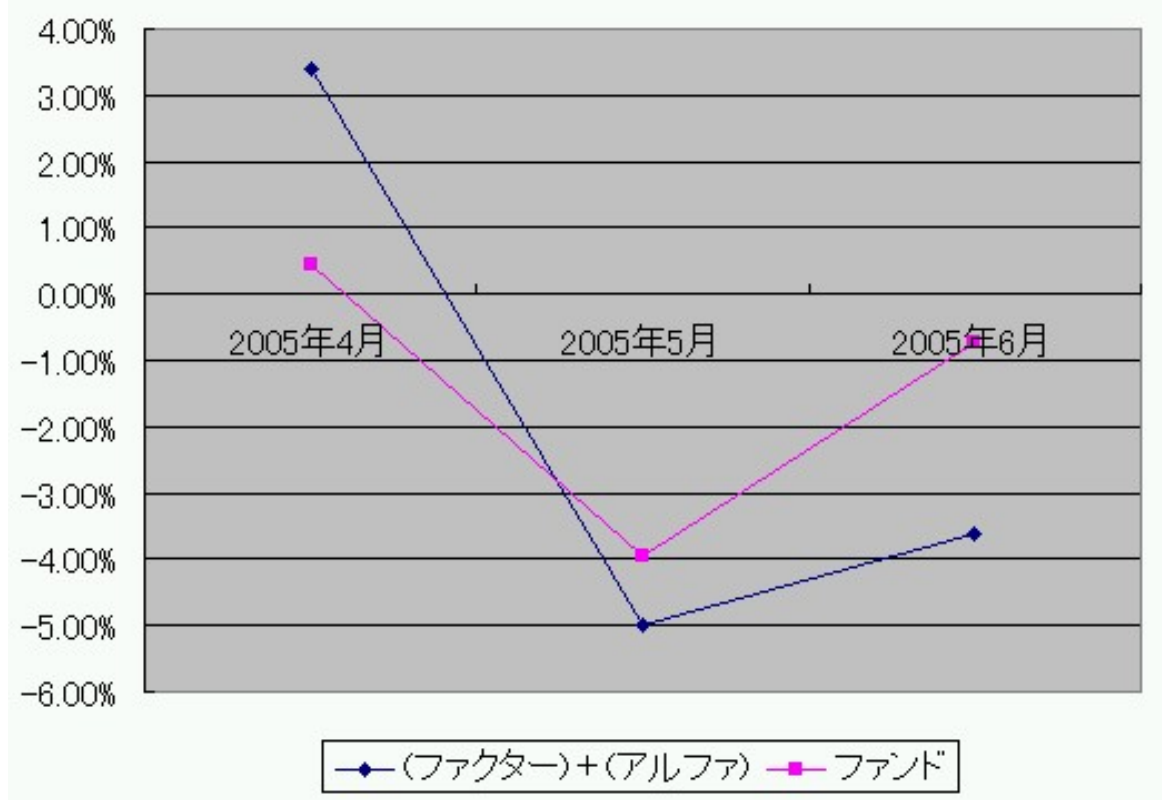

図 17: FUND105(Long / Short Equities) のリターンと (ファクターリターン) + (アルファ)

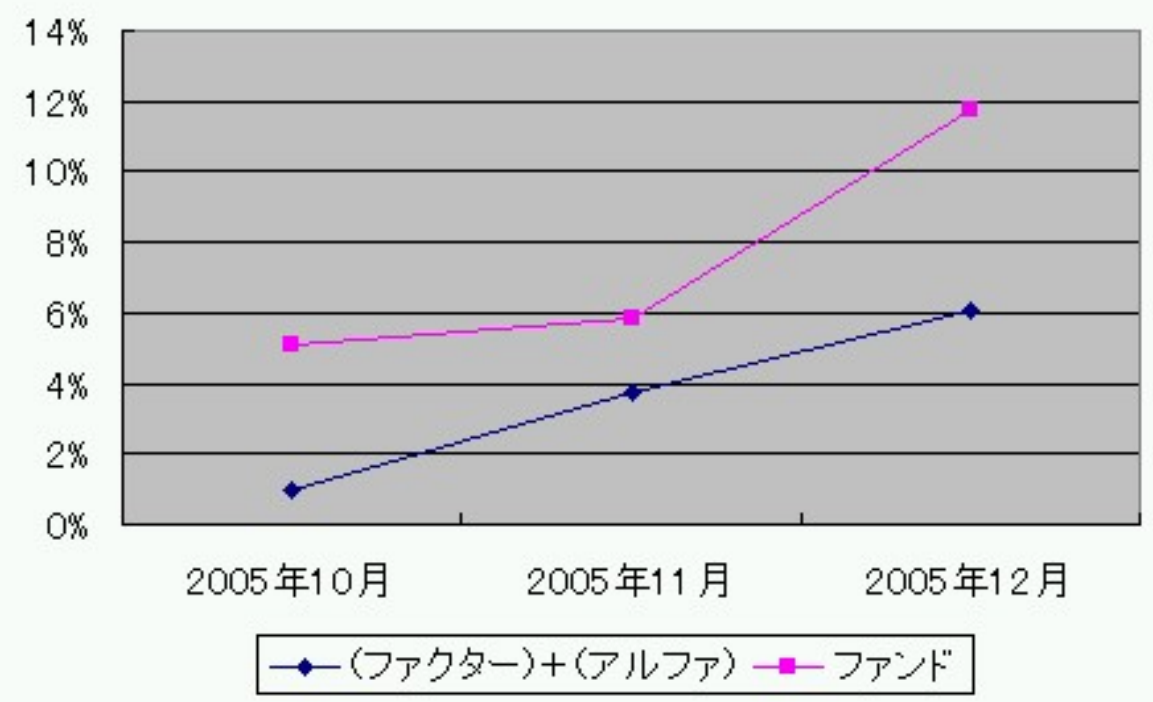

図 18: FUND73(Long / Short Equities) のリターンと (ファクターリターン) + (アルファ) 
クファクターの選択と要因分解の技術の向上が必要であるが、これらについ ては今後の研究課題としたい。 


\section{4 結論}

在アジアおよびアジア太平洋を投資対象とするヘッジファンドのポートフォ リオ構築という観点から実証研究を行った。まず、ヘッジファンドのリター ンの特性を調べた結果、非正規性と負のテイルリスクの重要性か確認された。 このことから、ヘッジファンドのポートフォリオ構築には従来の平均分散アプ ローチに替わるテイル部分を考慮した最適化手法が必要となる。我々は CVaR または CDD という2 つのリスク指標に制約を加えて期待収益率を最大化する Rockafellar and Uryasev (2000,2002), Chekhlov et al. (2000)のアルゴリズムを 利用して最適化を行った。この手法によれば、テイルリスクを抑えながら高 いリターンを期待することができる。out-of-sample の結果からへッジファン ドのポートフォリオ構築にはサンプル数が十分ある場合は CVaR, CDD 最適 化手法が強力な手法であることが確認された。また、シングルファンドへの 配分に資産の最大 $15 \%$ という制約を加え、上と同樣の作業を行い、結果の比 較を行った。集中投資を避けた場合、パフォーマンスを評価する指標が悪化 することが確認された。

さらに 39 のヘッジファンドに対し、リターンを株価インデックスなどの 市場で観測できるリスクファクターのリターンを説明変数として回帰分析を 行うことにより要因分解を行った。この結果から、各ファンドは状況に応じ て投資対象地域やスタイルを切り替えていることが分かる。したがってファ ンドの持つリスクを把握するためには非線形性を表すより適切なファクター を説明変数に加えるか、ファンドのエクスポージャーを動的に捉える必要が ある。

最後にポートフォリオ最適化とパフォーマンス分析を統合して、我々の手法 の実務への適用を示した。最適化によって構成されたポートフォリオの 2005 年のリターンをリスクファクターとファンドのアルファによって再現した。最 適化によって得られたポートフォリオのリターンを 2 ヶは再現できなかった が、12ヶ月中 10ヶ月は精度良く再現できた。ポートフォリオ最適化とパフォー マンス分析への我々のアプローチはファンド・オブ・ファンズ運用における ポートフォリオ構筑とリスク管理に有用であると思われる。さらに精度良く リターンを再現するためには、より適切なリスクファクターの選択と要因分 解の技術の向上が必要であるが、これらについては今後の研究課題としたい。 


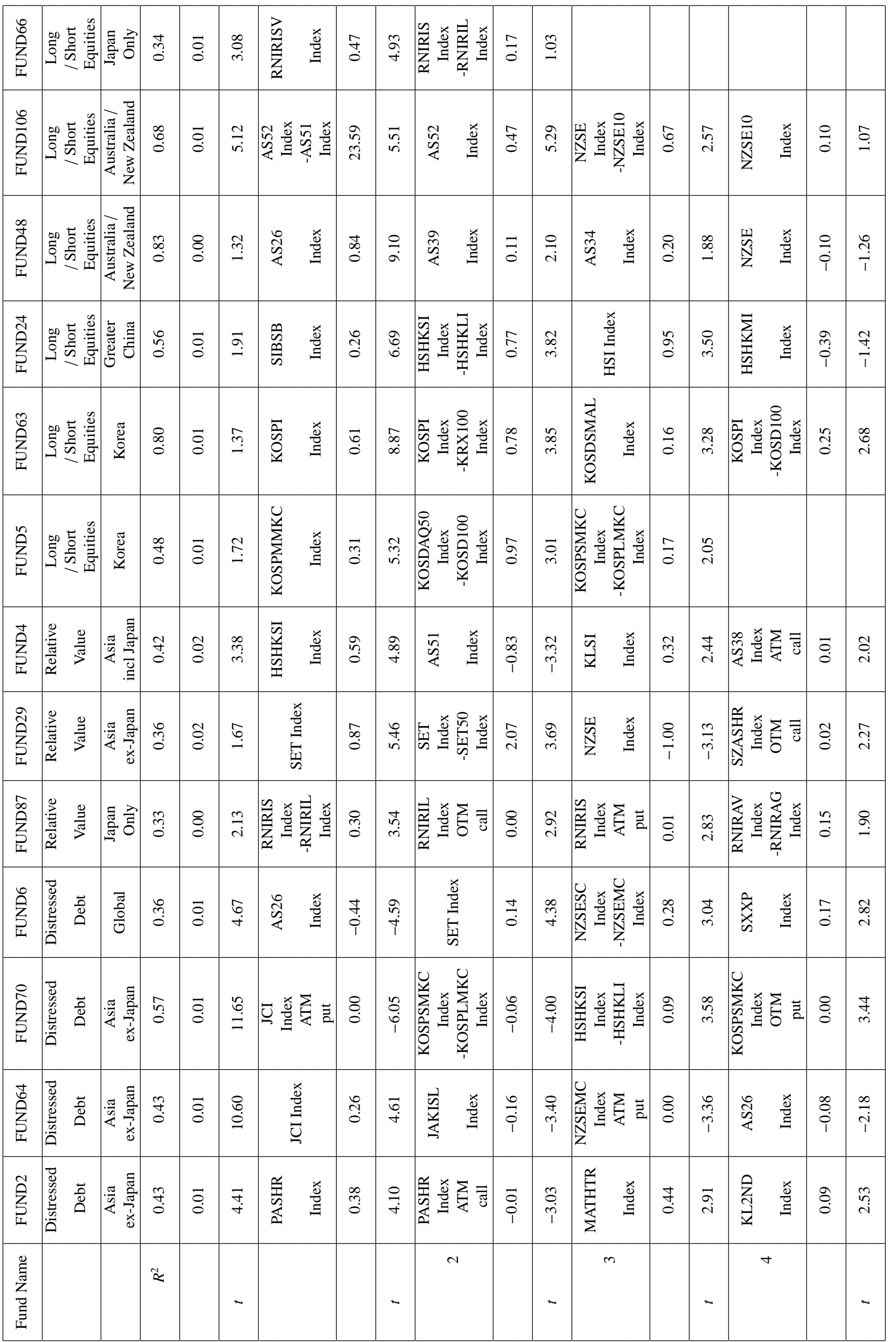




\begin{tabular}{|c|c|c|c|c|c|c|c|c|c|c|c|c|c|c|c|c|c|}
\hline$\overbrace{\text { 岺 }}^{\circ}$ & 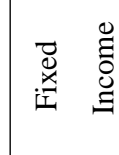 & 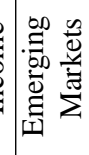 & $\stackrel{\widetilde{\sigma}}{0}$ & $\stackrel{8}{\circ}$ & $\begin{array}{l}\infty \\
0 \\
0 \\
1\end{array}$ & 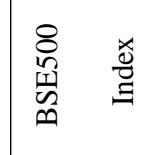 & m़ & $\stackrel{n}{6}$ & 窟 & $\stackrel{8}{0}$ & in & 恙 & $\stackrel{m}{0}$ & $\stackrel{\infty}{m}$ & 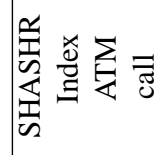 & $\stackrel{m}{0}$ & 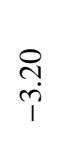 \\
\hline 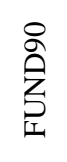 & 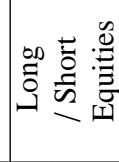 & 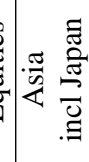 & F. & $\hat{\wp}_{i}$ & $\stackrel{0}{m}$ & 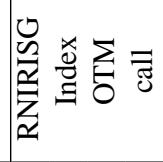 & $\ddot{\circ}$ & के & 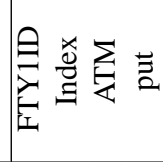 & $\stackrel{ \pm}{i}$ & $\stackrel{\infty}{\stackrel{p}{1}}$ & 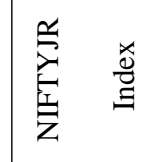 & $\begin{array}{l}\overline{\tilde{\varphi}} \\
\stackrel{1}{1}\end{array}$ & $\stackrel{\vec{p}}{\overrightarrow{1}}$ & 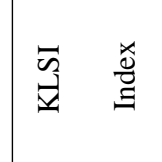 & กิ & $\stackrel{m}{i}$ \\
\hline 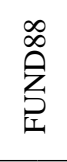 & on & S. & $\stackrel{n}{0}$ & $\stackrel{\text { ô. }}{0}$ & $\stackrel{\stackrel{q}{+}}{+}$ & 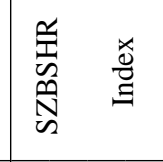 & $\stackrel{\infty}{0}$ & $\underset{+}{\stackrel{\leftrightarrow}{+}}$ & $\begin{array}{ll}\overrightarrow{0} \\
\stackrel{0}{n}\end{array}$ & $\tilde{\widetilde{o}}$ & $\stackrel{n}{\stackrel{n}{r}}$ & 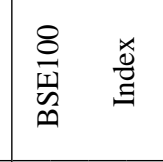 & กิ & $\stackrel{0}{m}$ & 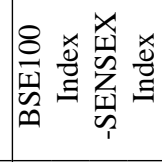 & $\stackrel{R}{0}$ & $\stackrel{i}{i}$ \\
\hline 灾 & 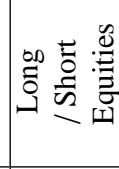 & 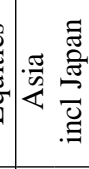 & $\stackrel{n}{0}$ & $\stackrel{8}{0}$ & $\stackrel{8}{\circ}$ & 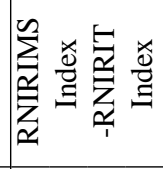 & $\tilde{n}$ & $\begin{array}{l}\infty \\
\text { ஸे }\end{array}$ & 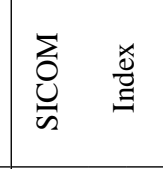 & in & $\begin{array}{l}+ \\
\stackrel{+}{i} \\
i\end{array}$ & 䍃肴 & $\stackrel{\infty}{0}$ & $\underset{\stackrel{\infty}{\infty}}{\stackrel{\infty}{i}}$ & 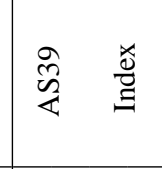 & $\stackrel{m}{0}$ & $\vec{n}$ \\
\hline 号 & 足 & 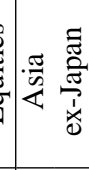 & $\bar{\sigma}$ & $\stackrel{0}{0}$ & $\underset{n}{\tilde{n}}$ & 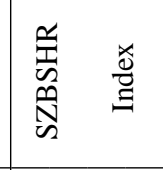 & $\stackrel{?}{+}$ & $\begin{array}{l}\text { ڤั } \\
\text { ते }\end{array}$ & 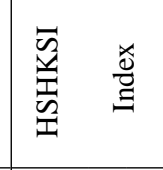 & n̊n & $\stackrel{0}{i n}$ & $\begin{array}{l}\underset{x}{0} \\
\vec{\Xi} \\
\tilde{\Xi} \\
\end{array}$ & ma & $\stackrel{8}{0}$ & 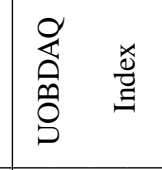 & $\stackrel{0}{0}$ & $\stackrel{5}{\dot{m}}$ \\
\hline 总 & 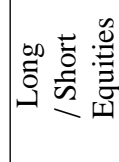 & $\frac{a}{a}$ & $\stackrel{\infty}{0}$ & $\stackrel{\overrightarrow{0}}{\circ}$ & $\stackrel{b}{0}$ & 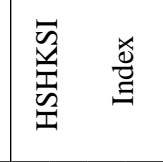 & $\stackrel{2}{0}$ & $\underset{\sim}{\stackrel{f}{r}}$ & 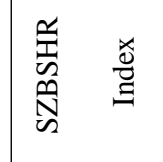 & $\stackrel{\infty}{0}$ & $\stackrel{7}{i}$ & 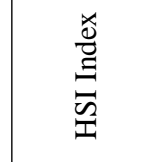 & ते & $\underset{\text { Dे }}{\stackrel{+}{1}}$ & 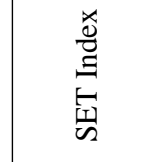 & $\stackrel{\Delta}{0}$ & nิ \\
\hline$\sum_{\substack{n \\
n}}^{n}$ & 我 & â & $\stackrel{2}{0}$ & $\stackrel{8}{\circ}$ & $\stackrel{n}{\vdots}$ & 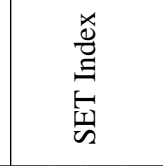 & $\stackrel{8}{\circ}$ & 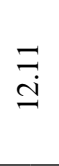 & 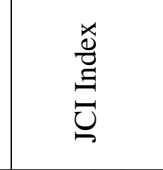 & $\stackrel{\widetilde{n}}{0}$ & $\ddot{m}$ & 至 & $\begin{array}{l}0 \\
\infty \\
0\end{array}$ & $\stackrel{\vec{n}}{n}$ & $\begin{array}{ll}\text { 芯 } \\
\text { 岕 }\end{array}$ & ñ & $\underset{i}{\stackrel{Q}{i}}$ \\
\hline$\sum_{\text {定 }}^{\infty}$ & 告 & 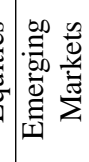 & $\overline{0}$ & $\stackrel{\text { ô. }}{0}$ & 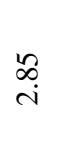 & 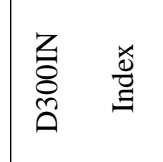 & $\stackrel{5}{0}$ & 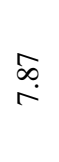 & 兽 & $\stackrel{0}{0}$ & $\underset{i}{\stackrel{q}{i}}$ & 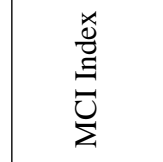 & $\frac{n}{0}$ & $\stackrel{\text { I }}{i}$ & 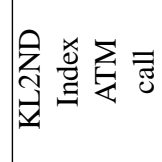 & $\stackrel{1}{0}$ & $\stackrel{\infty}{\stackrel{\sim}{\Lambda}}$ \\
\hline 官 & 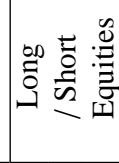 & 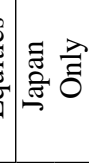 & ñ & $\stackrel{\text { ô. }}{0}$ & $\stackrel{\hat{r}}{\dot{m}}$ & 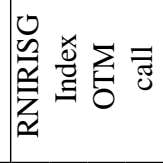 & $\stackrel{8}{0}$ & in & 总 & $\begin{array}{l}0 \\
0 \\
\end{array}$ & $\begin{array}{l}\vec{\infty} \\
\stackrel{i}{i}\end{array}$ & 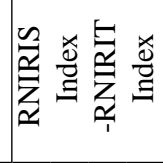 & $\stackrel{\infty}{\dddot{0}}$ & $\stackrel{\infty}{\vec{i}}$ & & & \\
\hline 灾 & 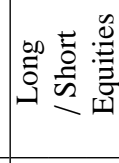 & 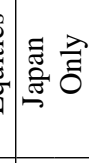 & $\stackrel{g}{0}$ & $\bar{\sigma}_{0}$ & $\underset{\sigma}{\sigma}$ & 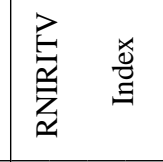 & ઼ָ & $\stackrel{\text { ָे }}{\mathrm{i}}$ & 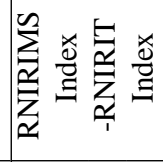 & ڤn. & $\stackrel{\infty}{n}$ & 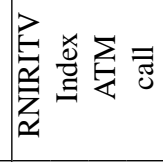 & $\ddot{\circ}$ & 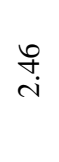 & & & \\
\hline 紊 & 贺 & 竎 & $\stackrel{0}{0}$ & $\ddot{\circ}$ & $\stackrel{0}{\circ}$ & 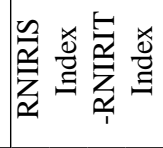 & $\stackrel{\circ}{\circ}$ & 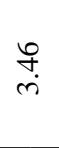 & & & & & & & & & \\
\hline 㟥 & on & 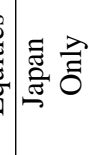 & 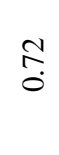 & $\stackrel{\text { ô. }}{0}$ & $\stackrel{\bullet}{=}$ & 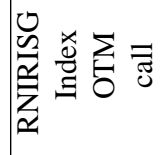 & $\ddot{0}$ & ñ & 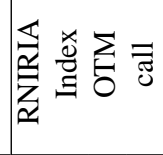 & $\stackrel{8}{\circ}$ & $\stackrel{m}{+}$ & 总 & $\ddot{0}$ & $\stackrel{\text { ָे }}{i}$ & & & \\
\hline 六 & 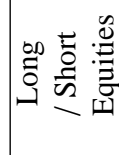 & 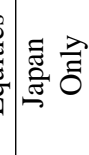 & $\stackrel{R}{0}$ & $\exists$ & $\stackrel{=}{i n}$ & 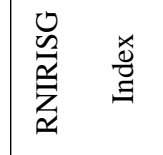 & $\stackrel{\overbrace{}}{\stackrel{\overbrace{}}{~}}$ & స్రి & 总 & $\stackrel{n}{0}$ & $\hat{\sigma}$ & 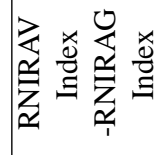 & $\stackrel{\text { f }}{\rightarrow}$ & $\begin{array}{l}n \\
i n\end{array}$ & 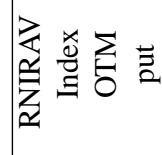 & $\bar{m}$ & $\underset{\stackrel{d}{+}}{\stackrel{t}{+}}$ \\
\hline 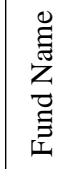 & 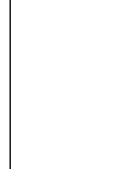 & 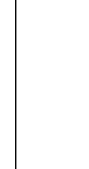 & 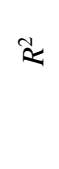 & $\frac{15}{5}$ & $\stackrel{\text { 畩 }}{\underline{L}}$ & 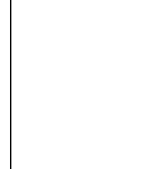 & 蘶 & $\stackrel{\text { 鰝 }}{=}$ & 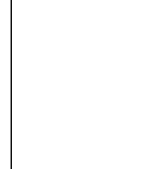 & 巍 & $\stackrel{\text { 鲒 }}{=}$ & 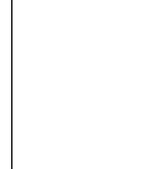 & 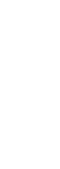 & $\stackrel{\text { 罴 }}{=}$ & 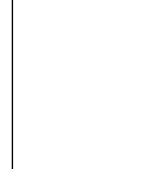 & 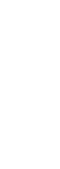 & $\stackrel{\text { t囬 }}{=}$ \\
\hline
\end{tabular}




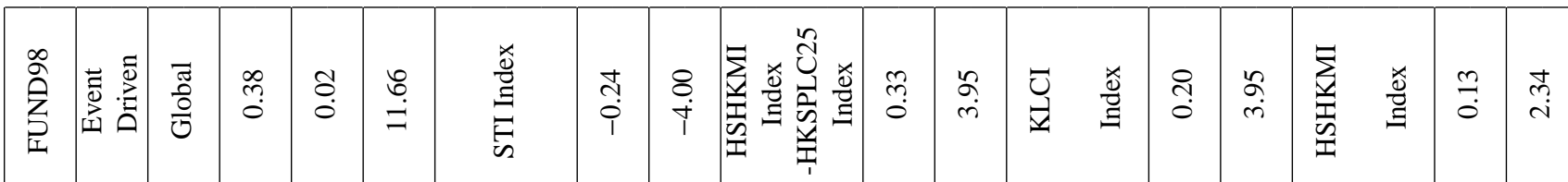

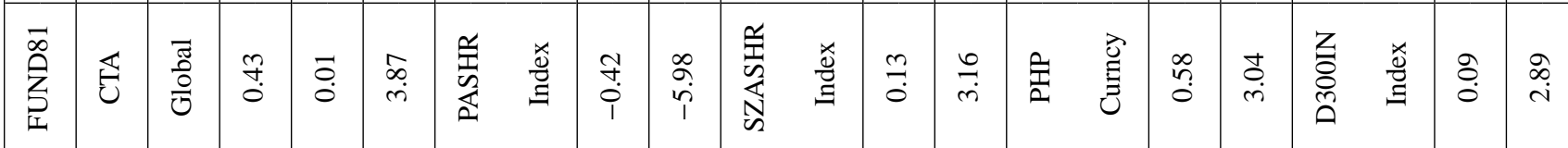

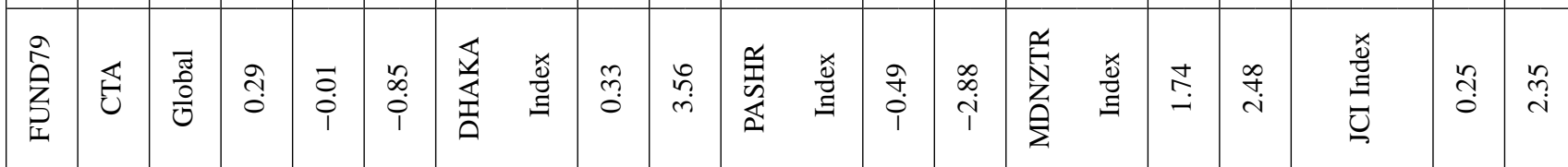

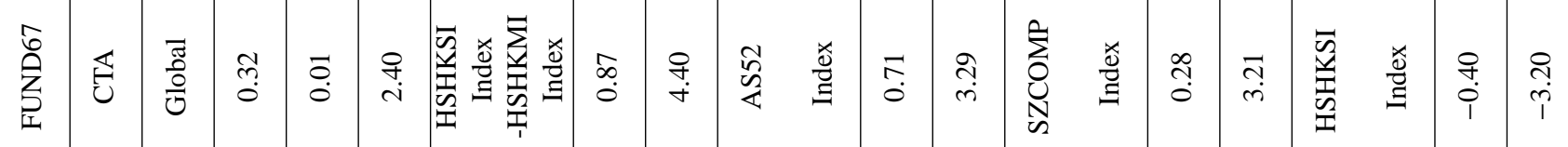

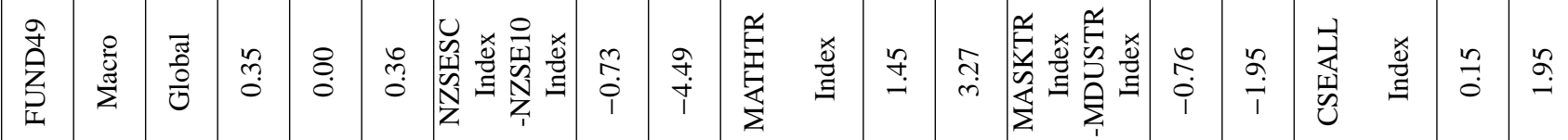

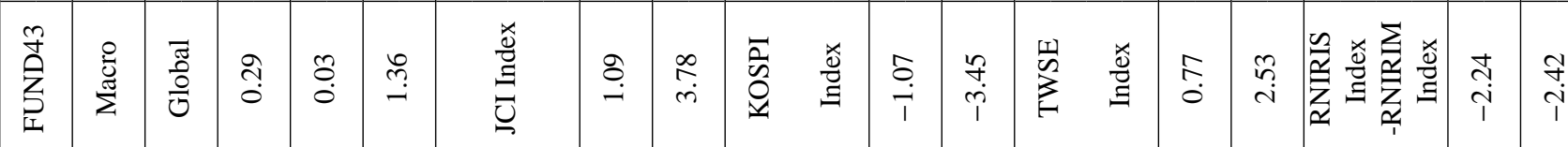

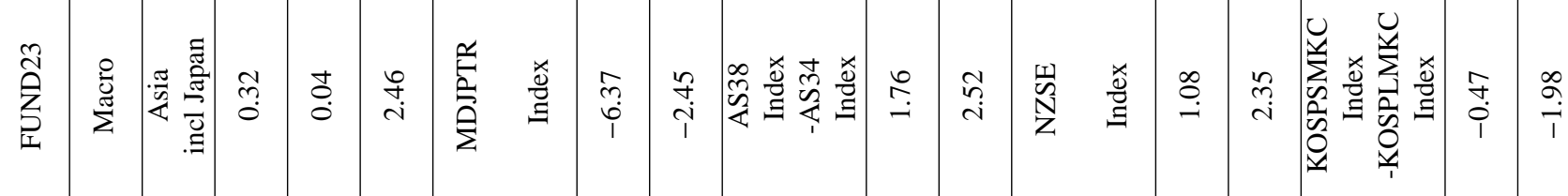

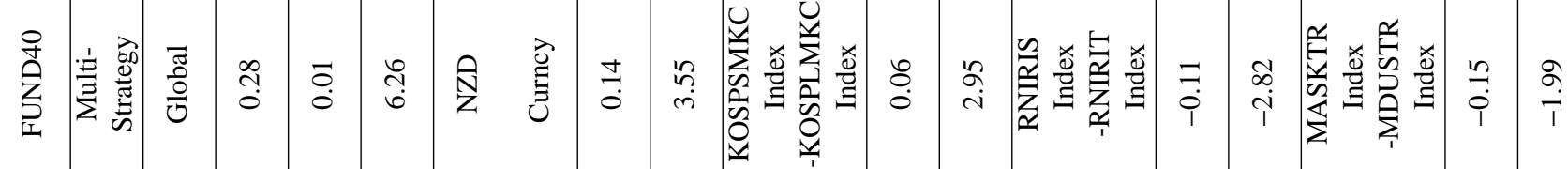

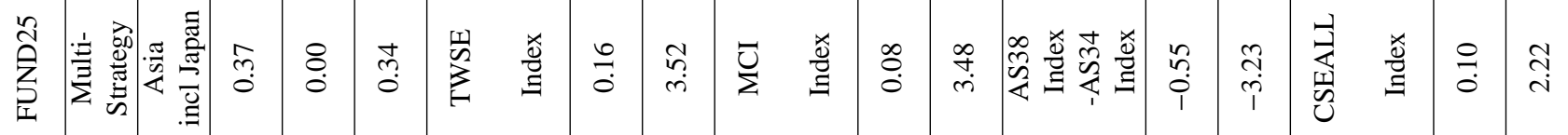

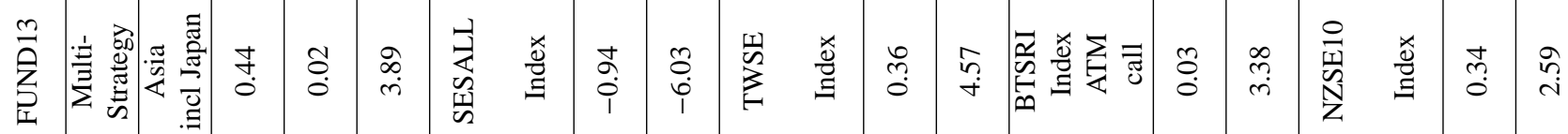

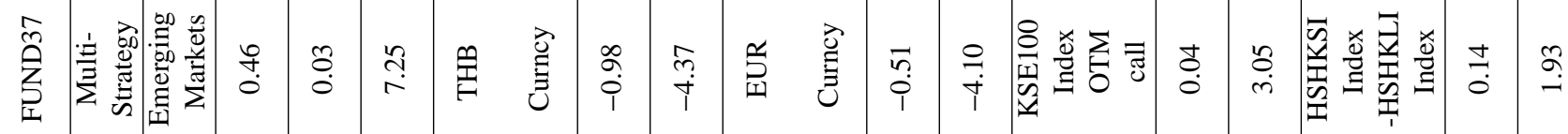

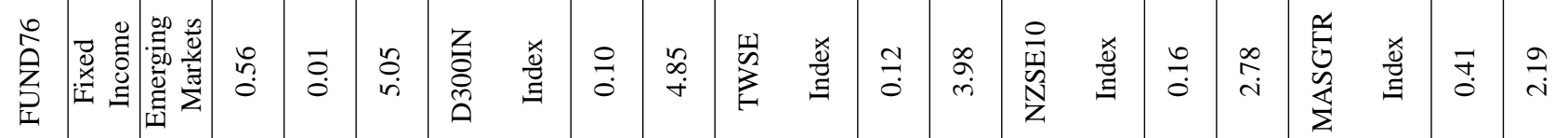

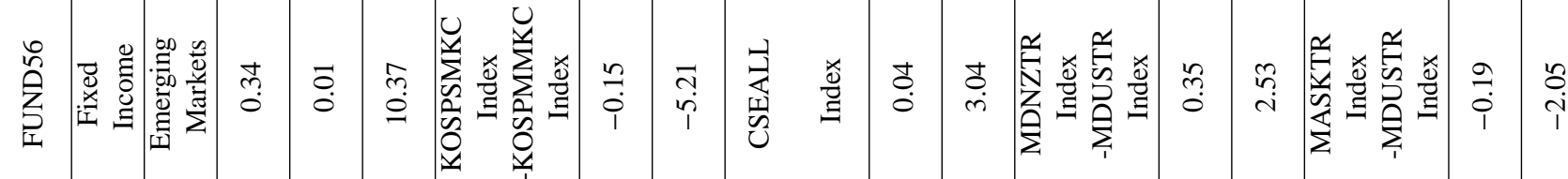

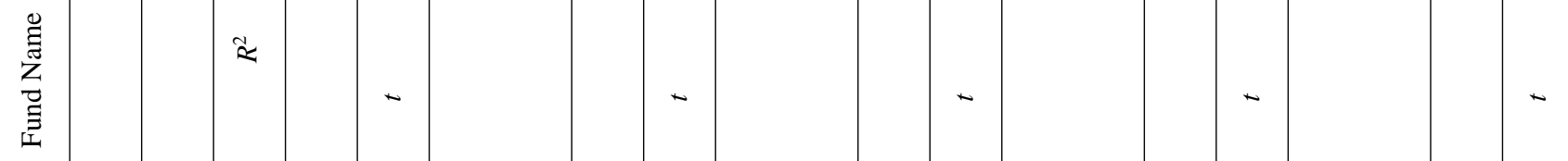




\begin{tabular}{|c|c|c|c|}
\hline 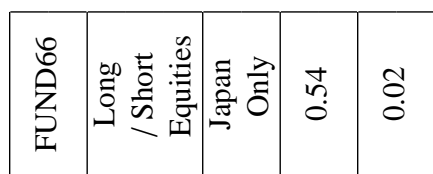 & 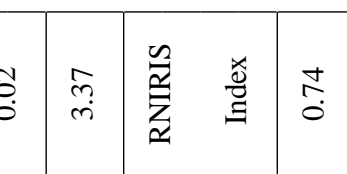 & 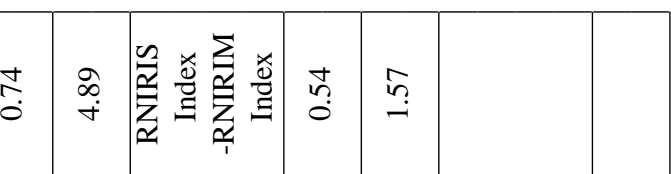 & \\
\hline 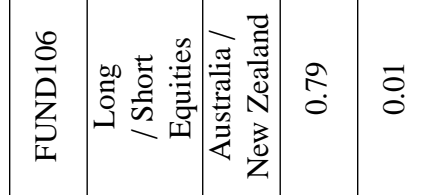 & 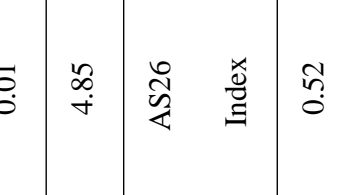 & 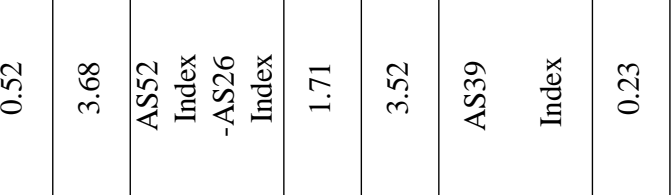 & 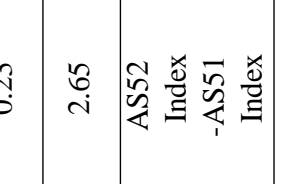 \\
\hline 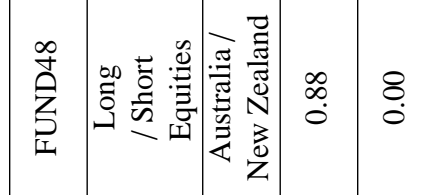 & 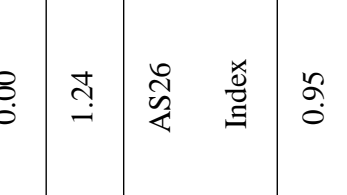 & 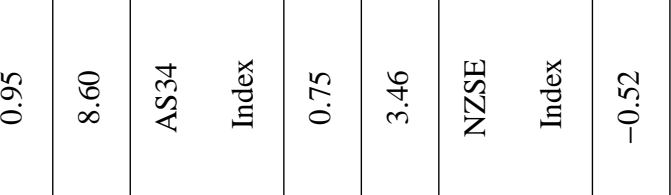 & 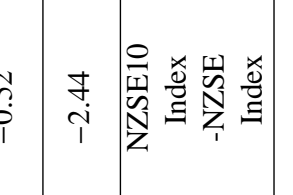 \\
\hline 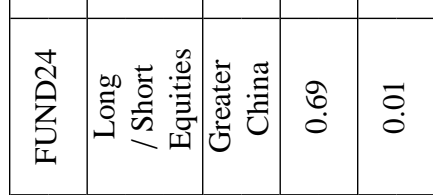 & 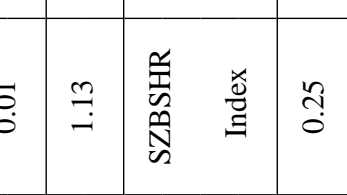 & 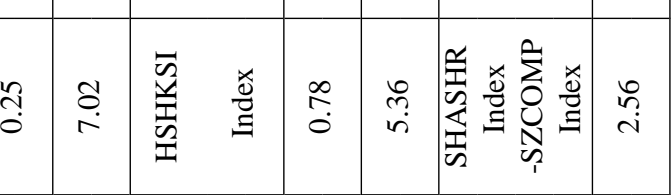 & 25 \\
\hline 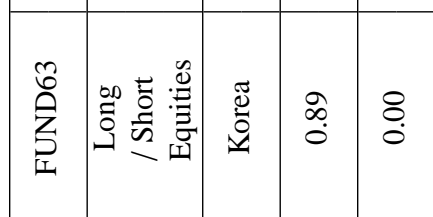 & 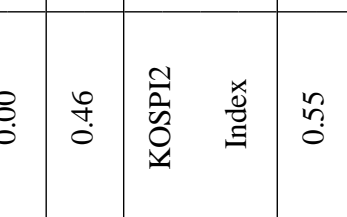 & 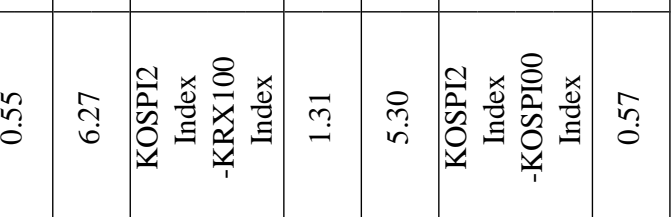 & 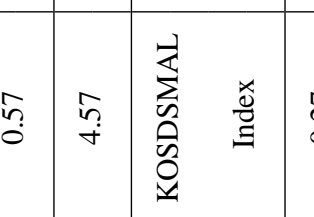 \\
\hline $5 \%$ & 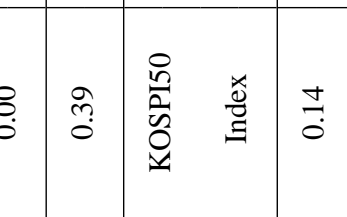 & 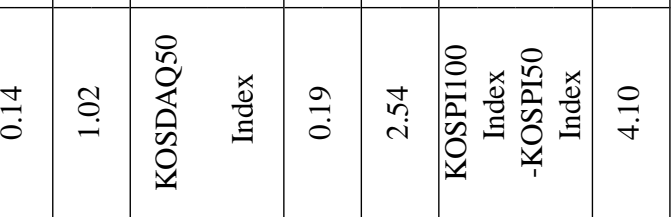 & 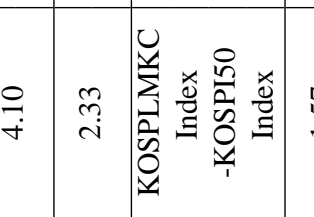 \\
\hline 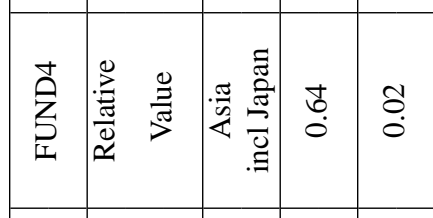 & 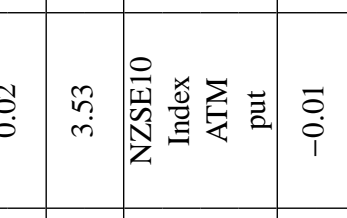 & 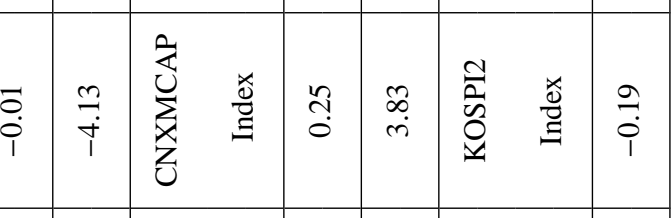 & $\frac{1}{2}$ \\
\hline 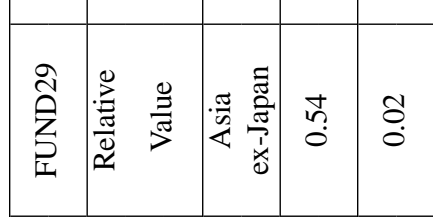 & 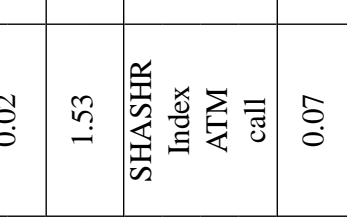 & 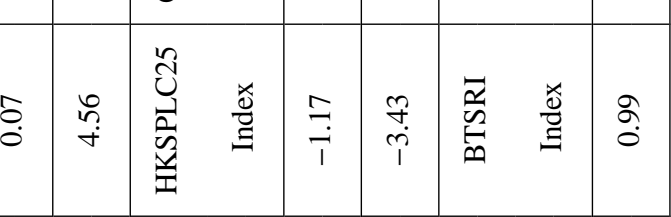 & 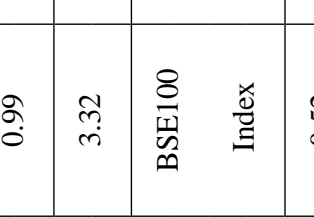 \\
\hline 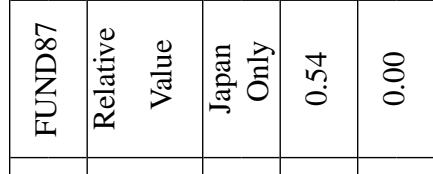 & 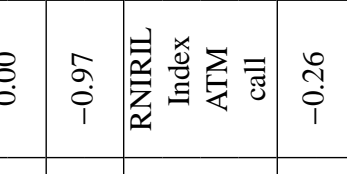 & 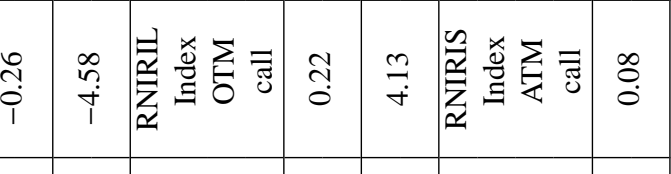 & 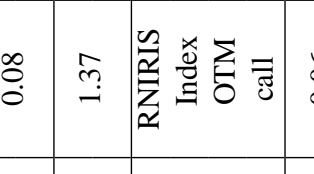 \\
\hline 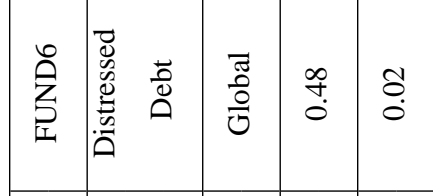 & 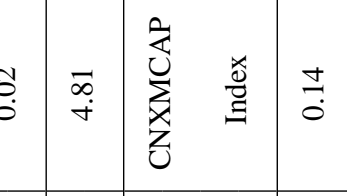 & 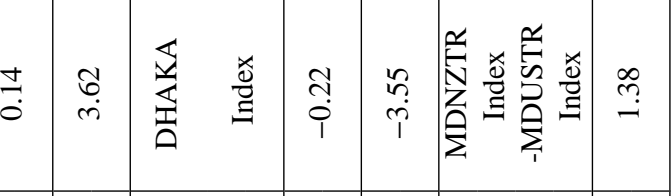 & $\frac{2}{2}$ \\
\hline 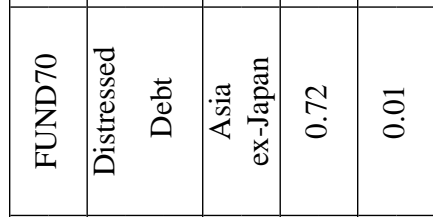 & 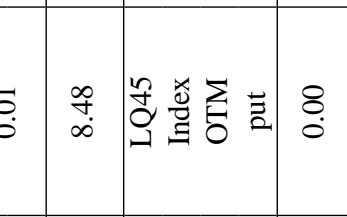 & 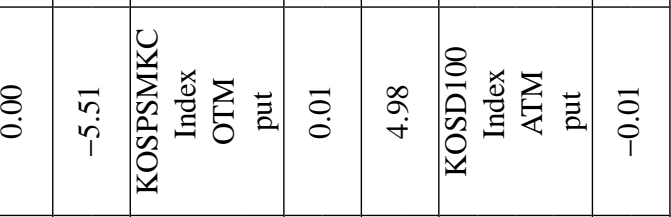 & 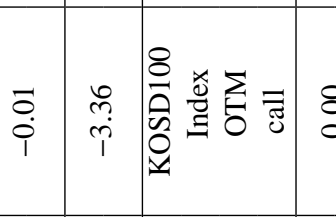 \\
\hline 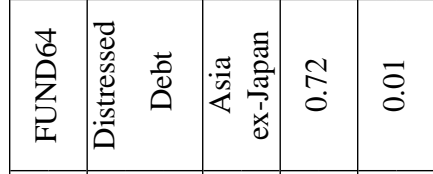 & $\frac{1}{2}$ & 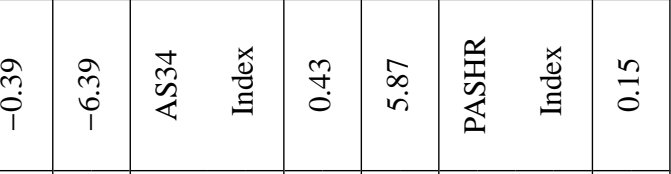 & 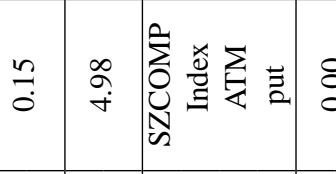 \\
\hline 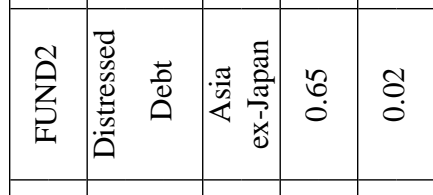 & 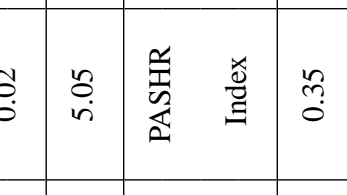 & 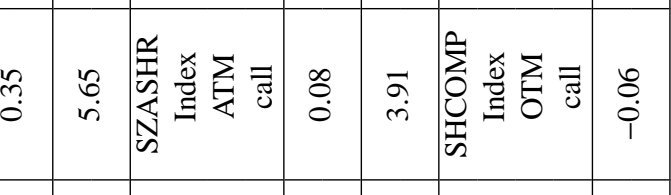 & 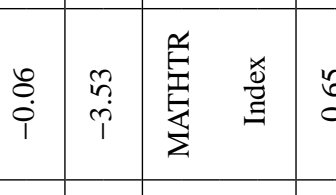 \\
\hline 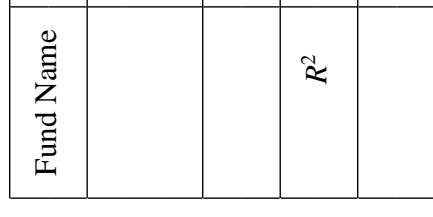 & 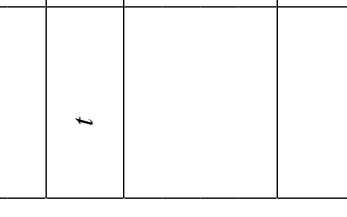 & 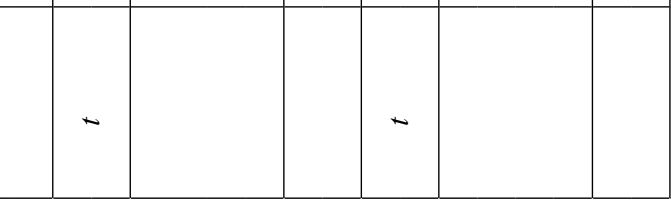 & 羍累意 \\
\hline
\end{tabular}




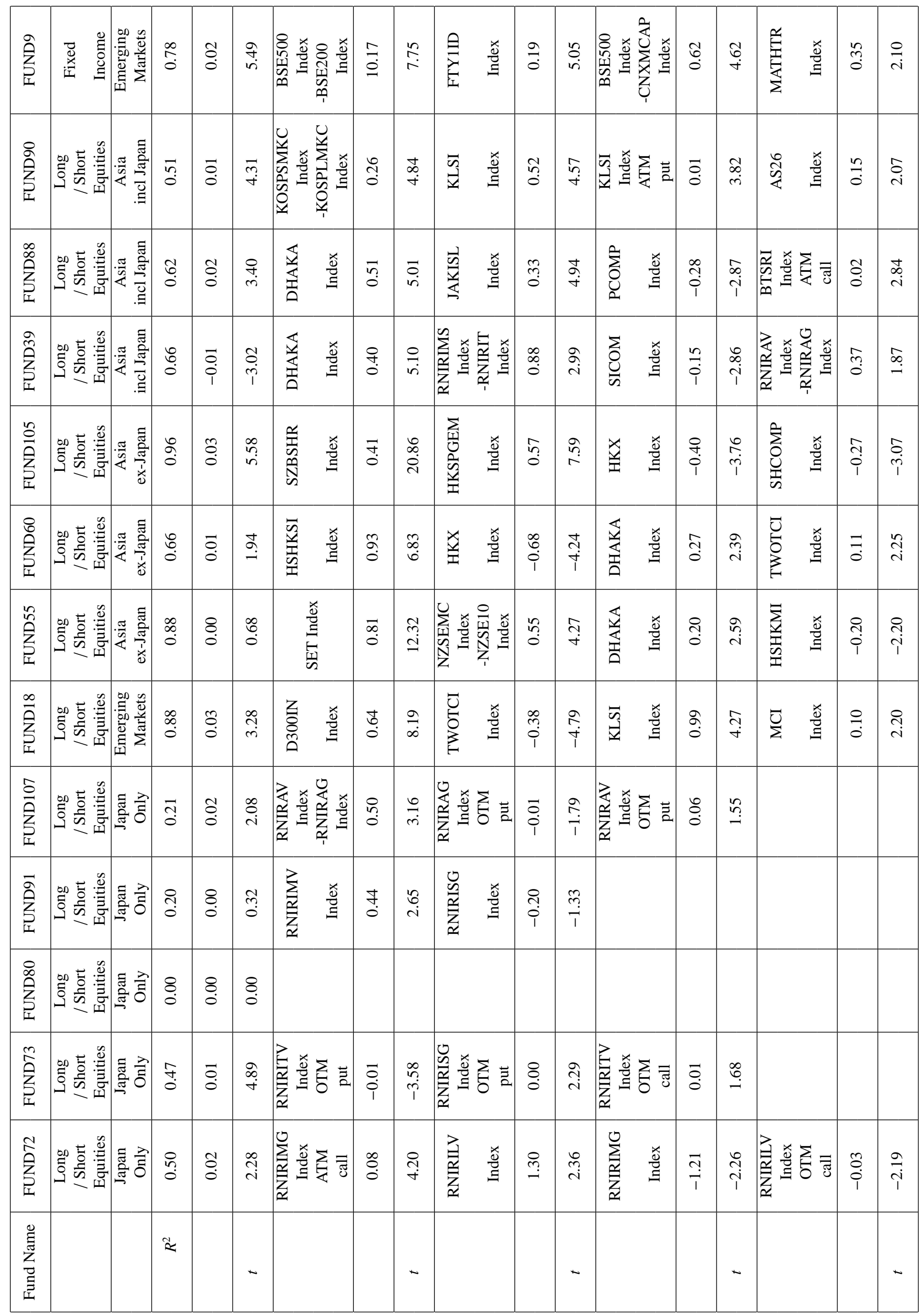




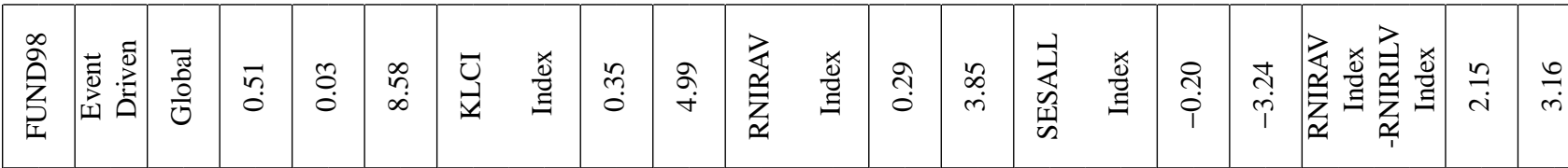

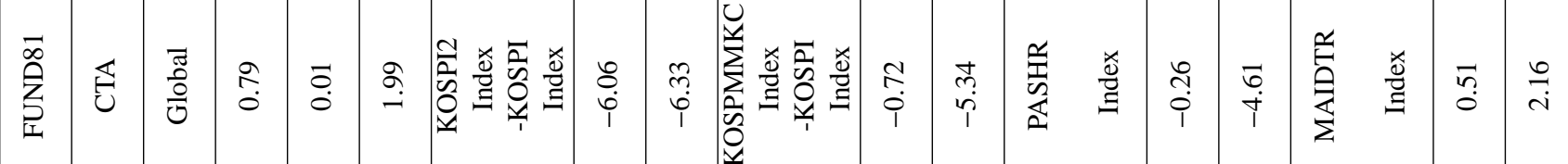

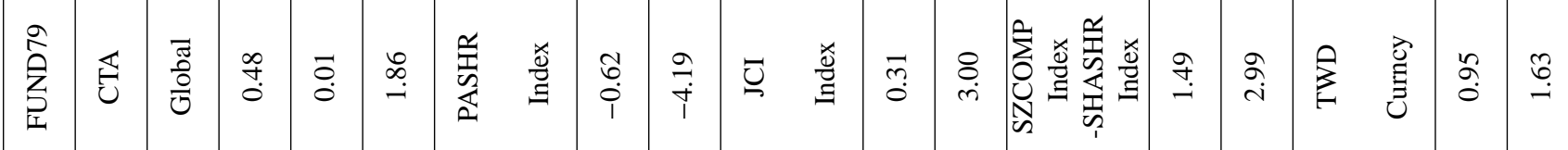

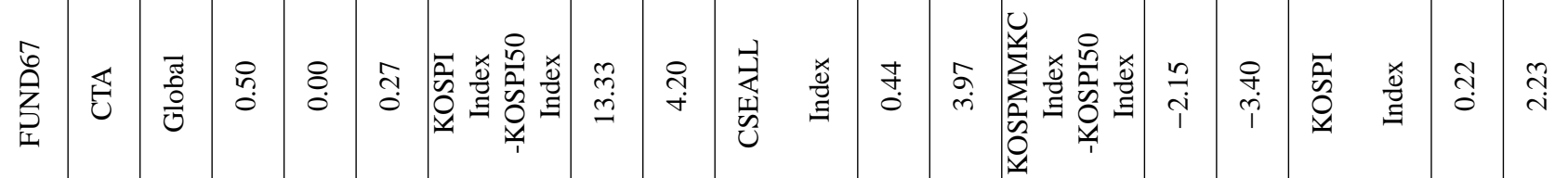

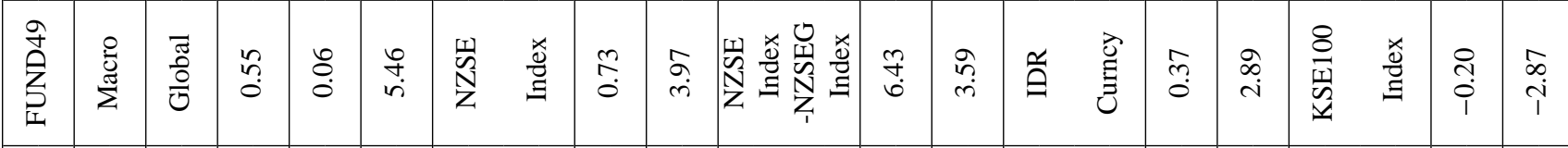

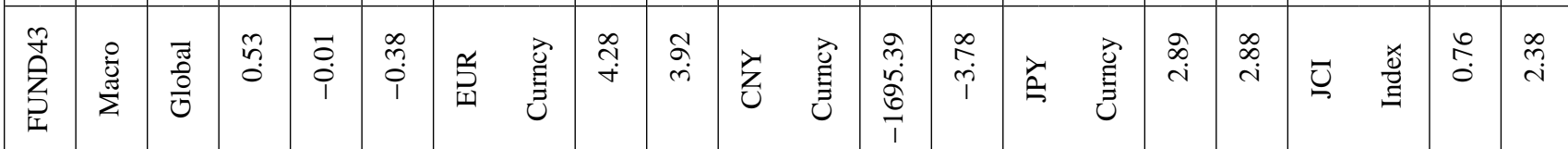

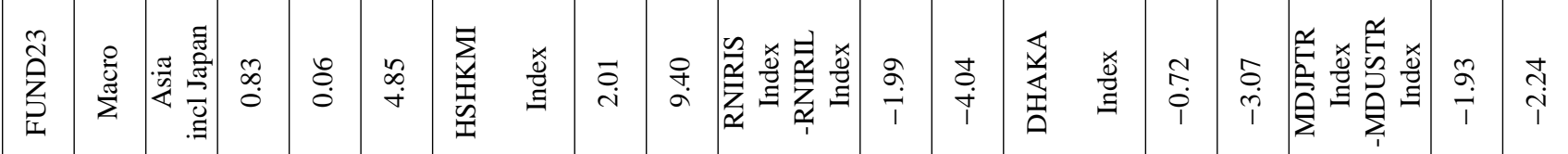

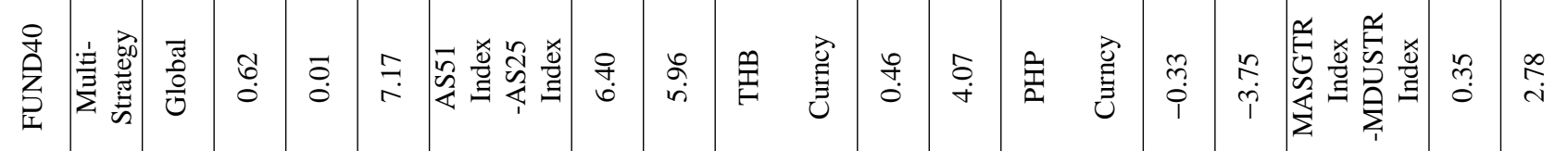

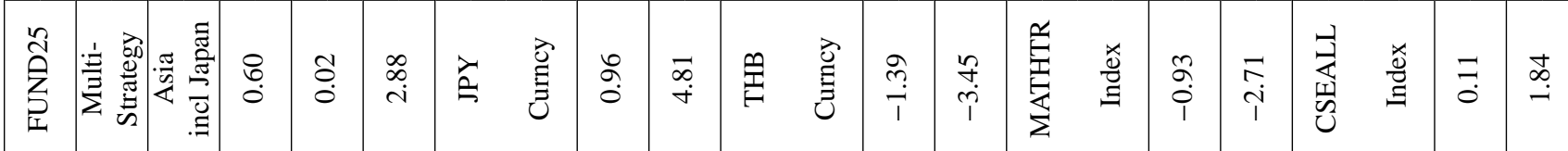

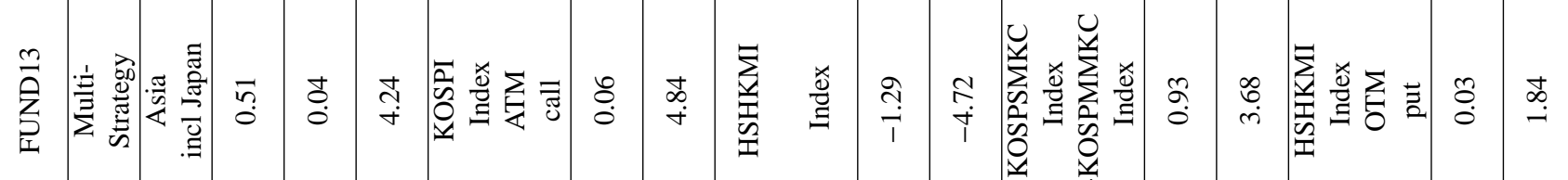

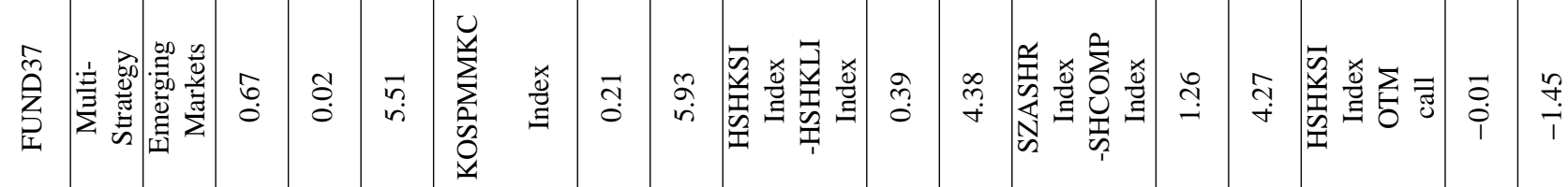

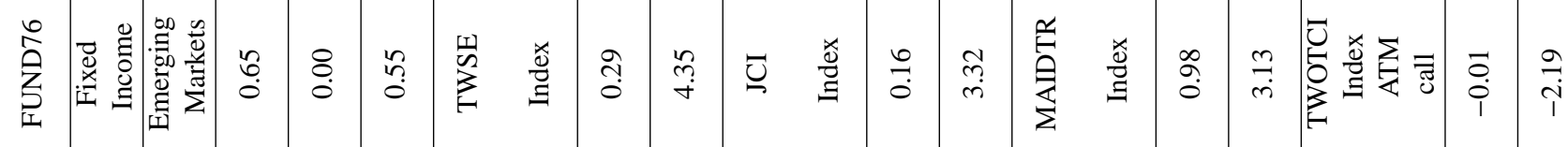

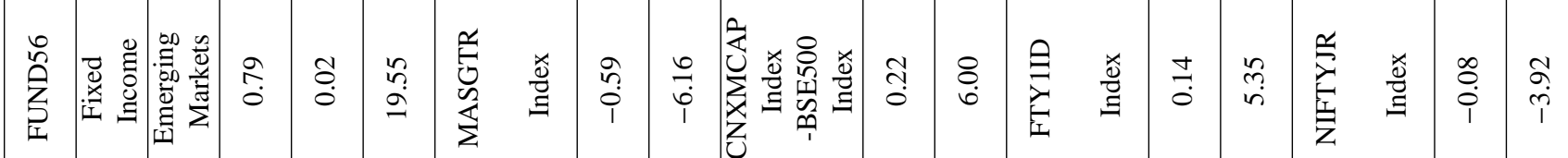

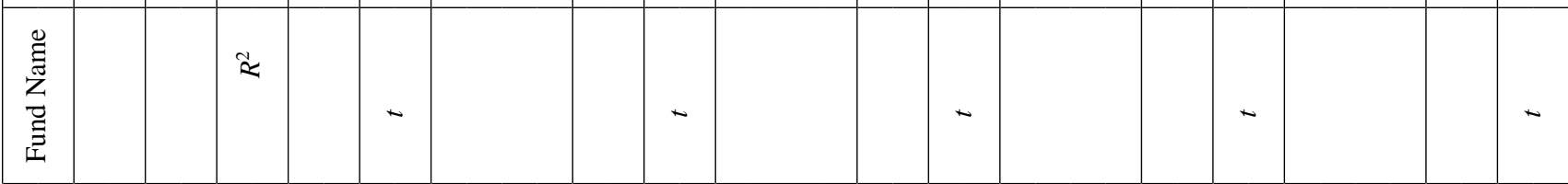




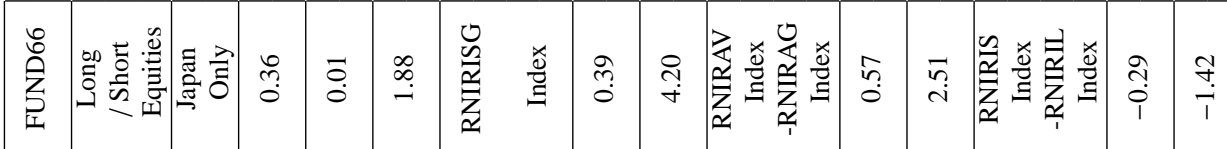

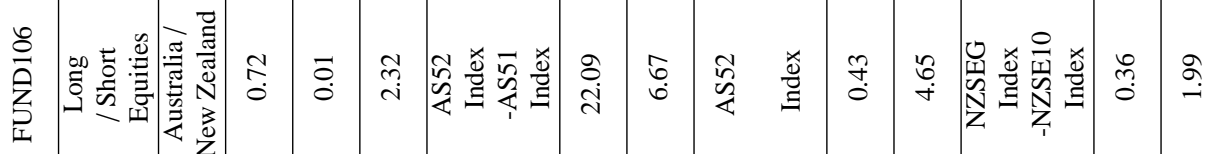

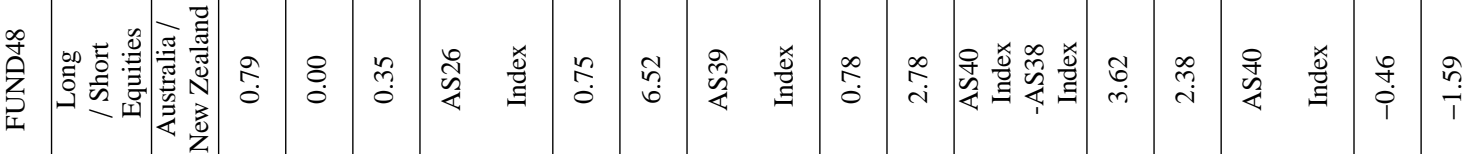

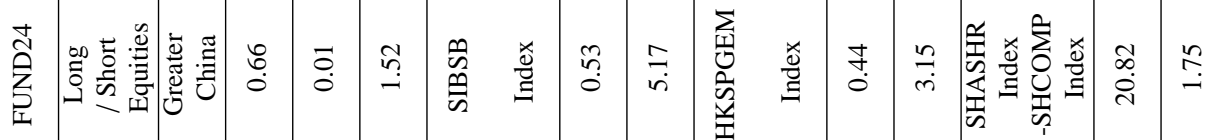

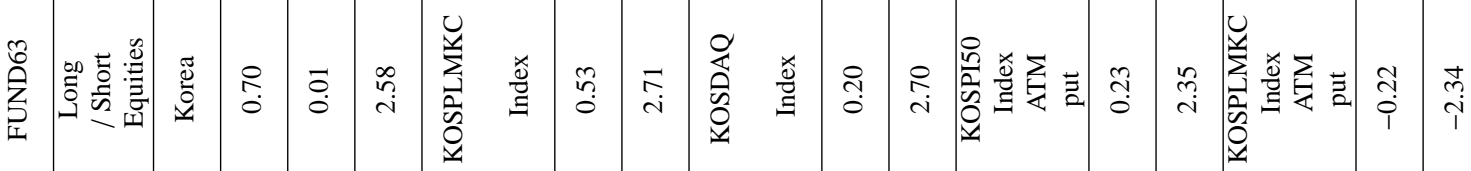

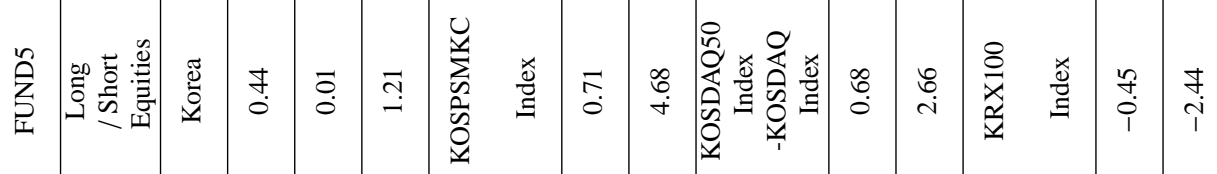

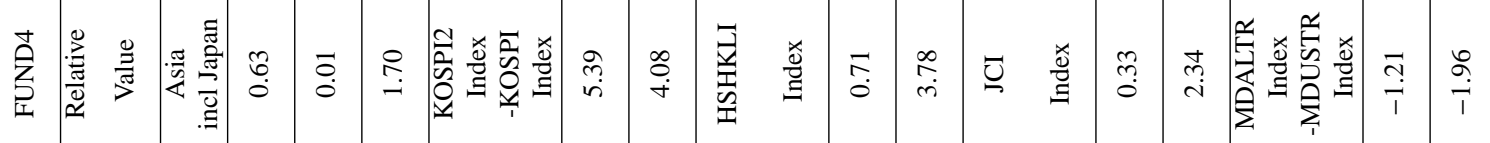

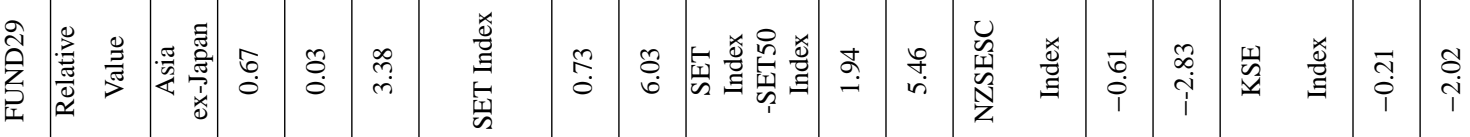

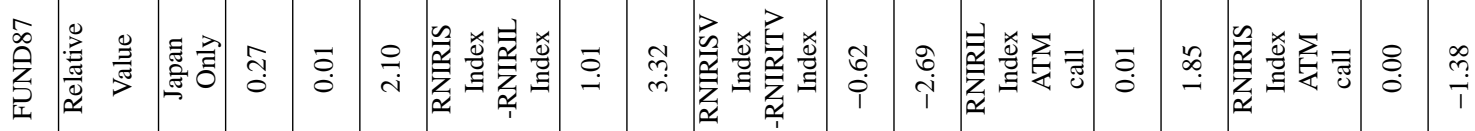

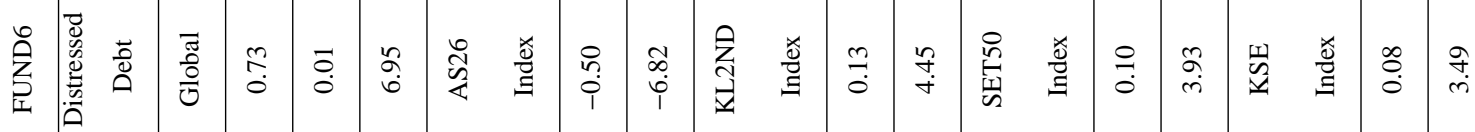

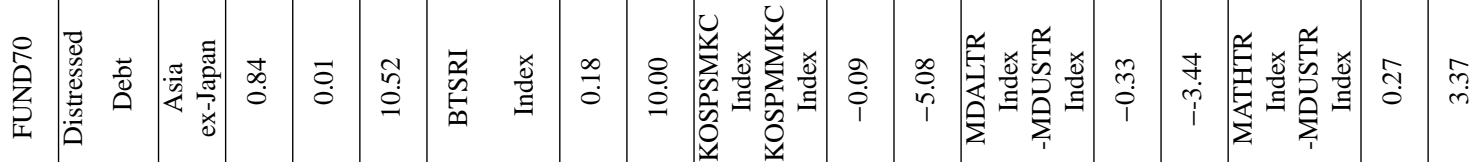

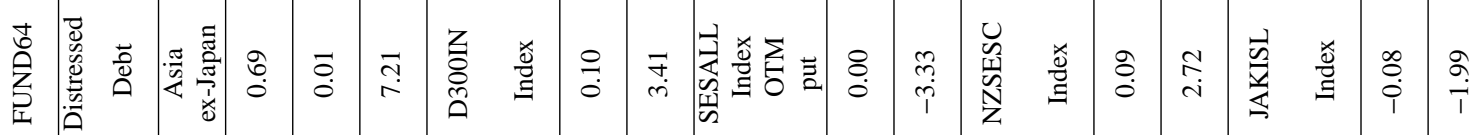

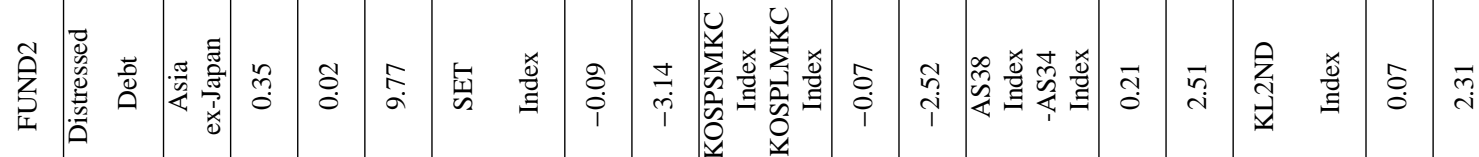

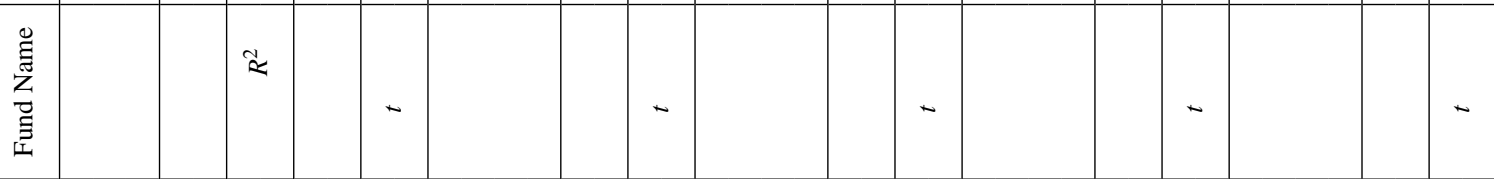




\begin{tabular}{|c|c|c|}
\hline 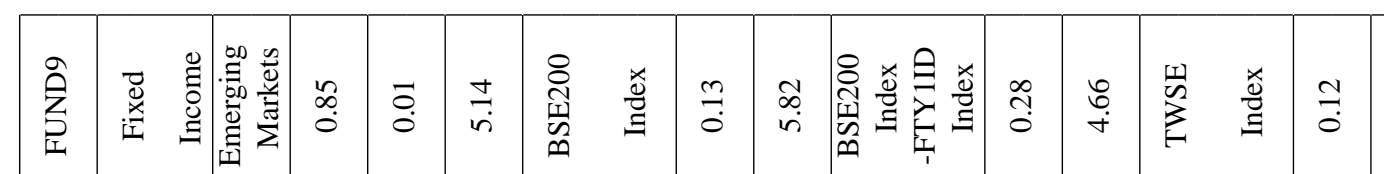 & 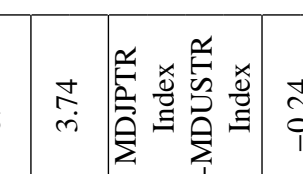 & \\
\hline 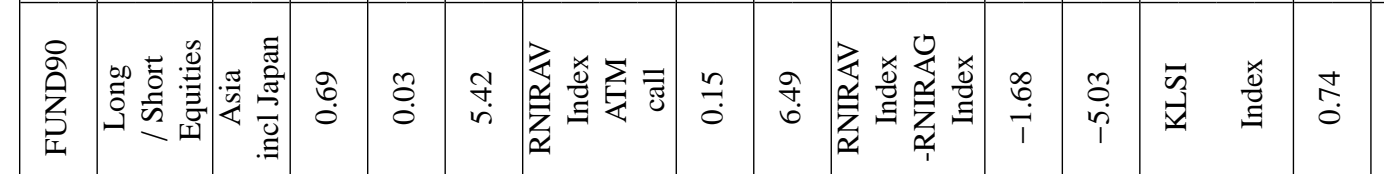 & 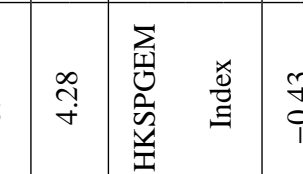 & \\
\hline 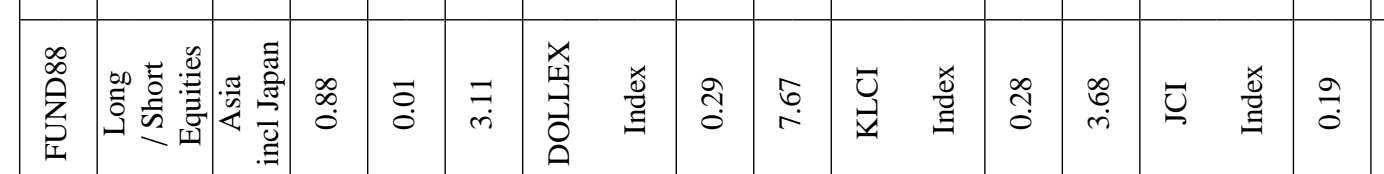 & 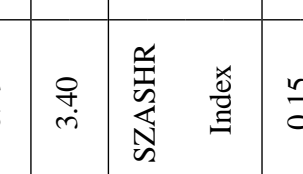 & \\
\hline 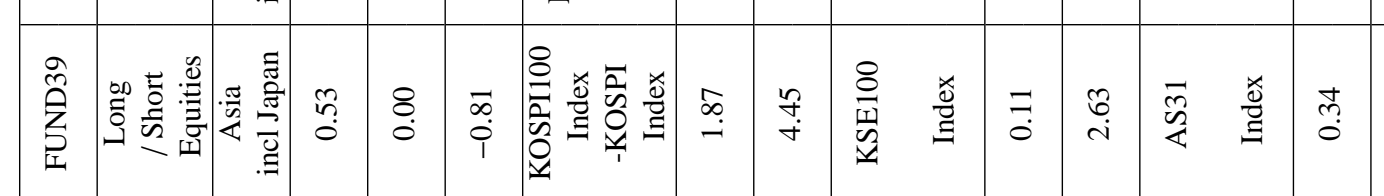 & & \\
\hline 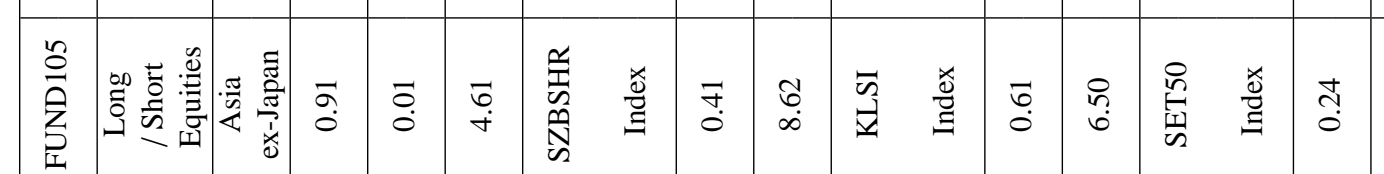 & 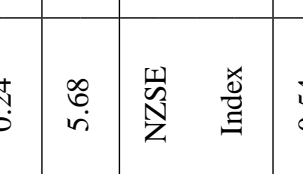 & \\
\hline 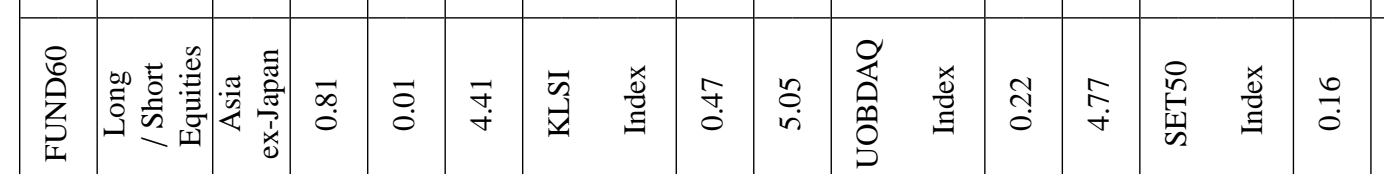 & 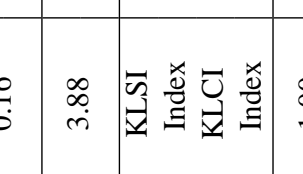 & \\
\hline 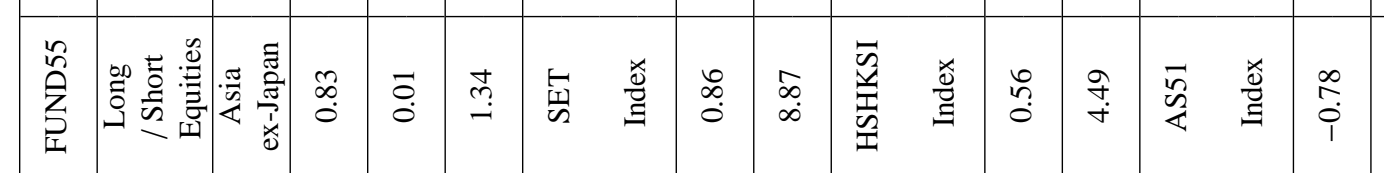 & 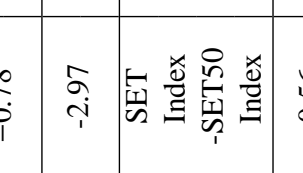 & \\
\hline 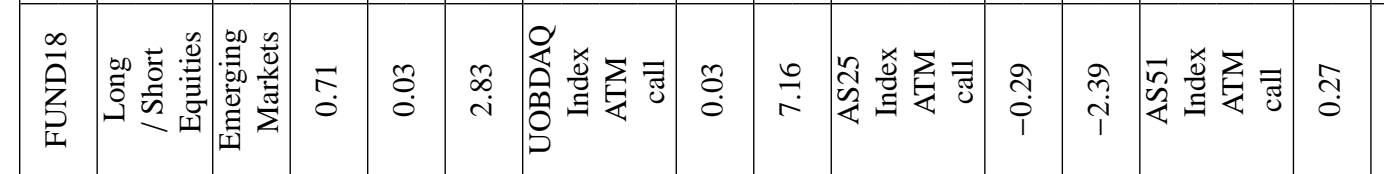 & 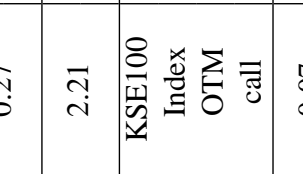 & \\
\hline 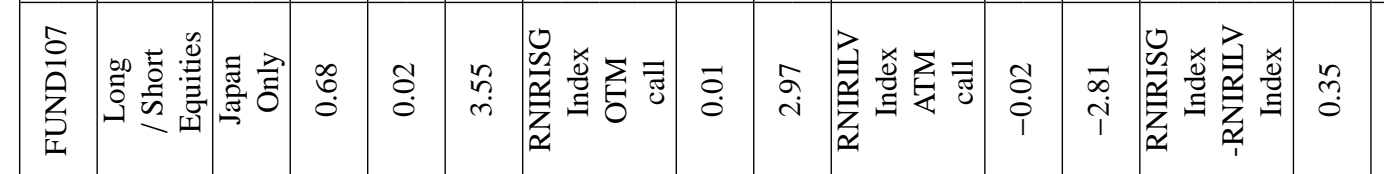 & $\frac{0}{2}$ & \\
\hline 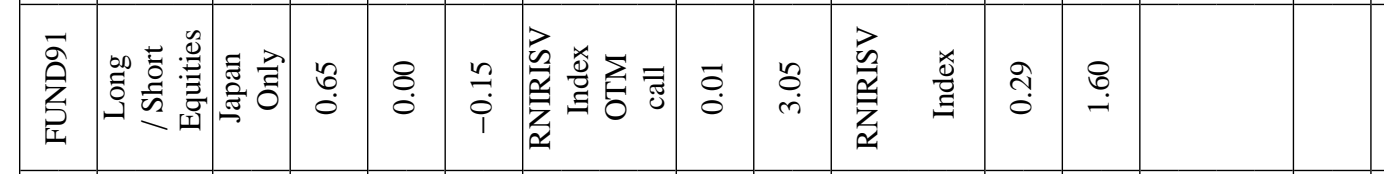 & & \\
\hline 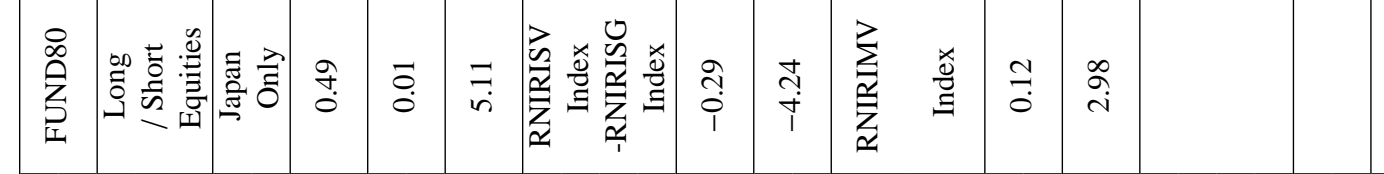 & & \\
\hline 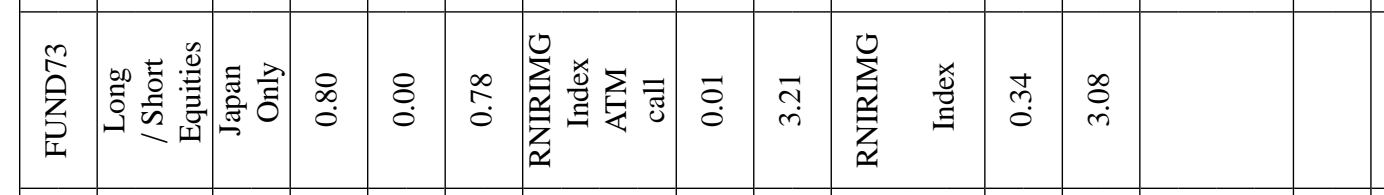 & & \\
\hline 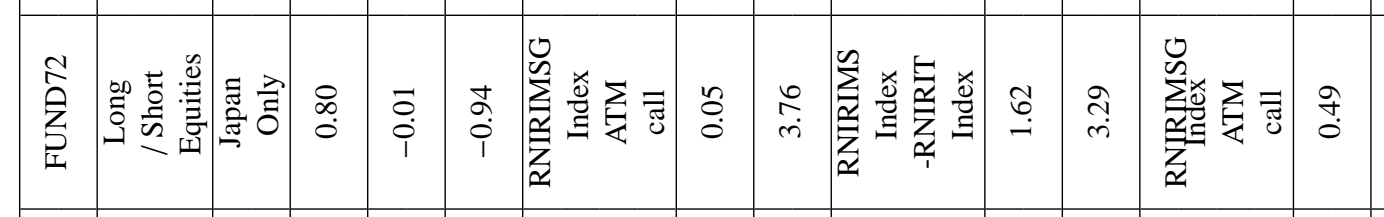 & & \\
\hline 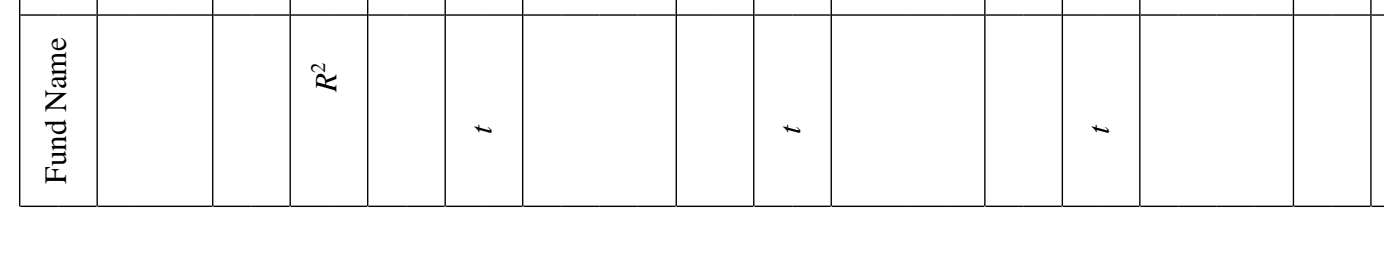 & & \\
\hline
\end{tabular}




\begin{tabular}{|c|c|c|c|c|c|c|c|c|c|c|c|c|c|c|c|c|c|}
\hline$\sum_{\substack{1\\
}}^{\infty}$ & 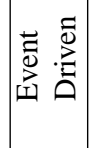 & $\begin{array}{l}\bar{\sigma} \\
0 \\
0 \\
0\end{array}$ & $n$ & $\stackrel{\text { Oै }}{0}$ & $\tilde{a}$ & 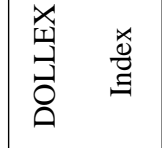 & $\stackrel{0}{0}$ & $\begin{array}{l}\infty \\
\dot{m}\end{array}$ & 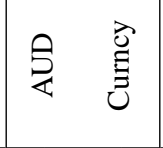 & 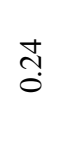 & $\stackrel{\tilde{r}}{\dot{r}}$ & 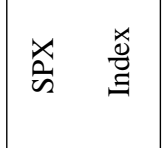 & त̂ & $\underset{i}{\stackrel{g}{i}}$ & 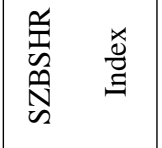 & $\stackrel{8}{\circ}$ & $\stackrel{\infty}{\leftrightarrow}$ \\
\hline 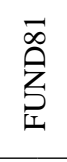 & $\mathbb{E}$ & $\begin{array}{l}\overline{0} \\
\frac{0}{0} \\
\text { U }\end{array}$ & $\stackrel{n}{n}$ & $\ddot{\circ}$ & $\stackrel{+}{m}$ & 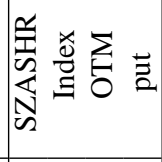 & $\stackrel{0}{0}$ & $\overrightarrow{\vec{p}}$ & 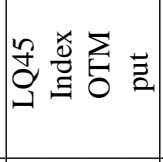 & $\stackrel{n}{0}$ & $\stackrel{8}{\leftrightarrow}$ & も & $\begin{array}{l}0 \\
0 \\
0 \\
1\end{array}$ & $\begin{array}{l}\infty \\
\infty \\
i\end{array}$ & 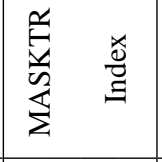 & $\stackrel{\hat{0}}{\hat{0}}$ & in \\
\hline 悀 & 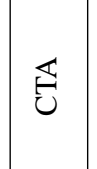 & $\begin{array}{l}\overline{0} \\
\text { 음 }\end{array}$ & $\begin{array}{l}0 \\
0 \\
0\end{array}$ & $\stackrel{8}{0}$ & $\stackrel{n}{0}$ & $\begin{array}{ll}\text { 点 } & \text { 蒠 }\end{array}$ & ک̊ & $\begin{array}{l}\vec{\infty} \\
\dot{n}\end{array}$ & 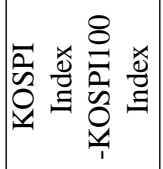 & 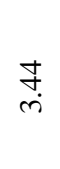 & $\begin{array}{l}\tilde{\sigma} \\
\dot{r}\end{array}$ & 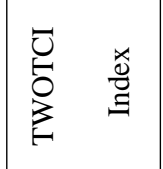 & ते & $\stackrel{8}{\dot{m}}$ & 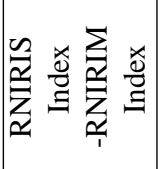 & $\hat{\grave{i}}$ & ָे \\
\hline 它 & 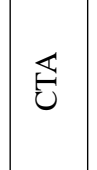 & 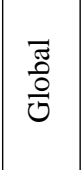 & $\stackrel{0}{0}$ & $\stackrel{8}{\circ}$ & ర్ర & 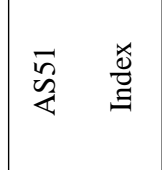 & $\hat{o}$ & $\stackrel{\stackrel{\mathscr{V}}{+}}{+}$ & 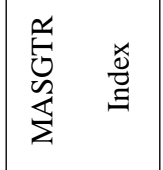 & $\stackrel{\infty}{\stackrel{\infty}{i}}$ & $\stackrel{\text { f̀ }}{\stackrel{i}{1}}$ & 足点 & ñ? & $\underset{\substack{q \\
i}}{i}$ & 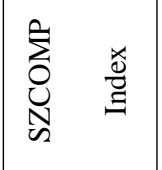 & $\stackrel{\infty}{\stackrel{0}{0}}$ & तु \\
\hline$\sum_{\text {守 }}^{\text {它 }}$ & 莺 & $\begin{array}{l}\overline{0} \\
\text { ô } \\
\text { 0 }\end{array}$ & $\stackrel{5}{0}$ & $\stackrel{+}{0}$ & $\frac{a}{\dot{i}}$ & 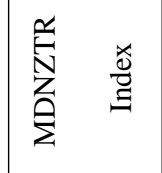 & ڤn & ج़े & 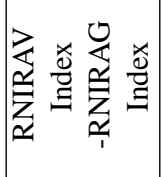 & $\stackrel{\beta}{-}$ & $\stackrel{\text { q̊ }}{+}$ & 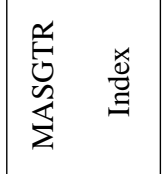 & $\underset{\overbrace{}}{i}$ & $\stackrel{m}{\oplus}$ & 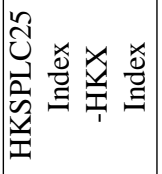 & $\stackrel{\mathscr{n}}{i}$ & $\stackrel{\text { ڤे }}{\text { ஸे }}$ \\
\hline 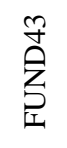 & 莺 & $\begin{array}{l}\bar{\sigma} \\
0 \\
0 \\
0\end{array}$ & $\begin{array}{l}\mathbb{1} \\
0 \\
0\end{array}$ & $\stackrel{+}{0}$ & $\overrightarrow{\widetilde{i}}$ & 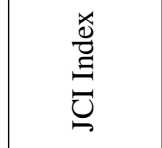 & $\stackrel{T}{i}$ & $\vec{n}$ & 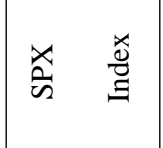 & $\vec{\infty}$ & $\stackrel{+}{n}$ & 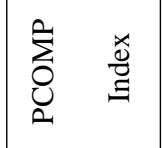 & $\stackrel{\substack{+i}}{i}$ & aे & 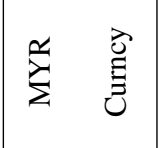 & $\begin{array}{l}: \\
\stackrel{0}{0}\end{array}$ & $\underset{i}{\stackrel{J}{i}}$ \\
\hline 芯 & 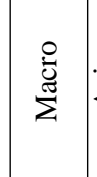 & 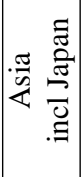 & $n$ & $\stackrel{\overrightarrow{0}}{\circ}$ & $\stackrel{+}{\sharp}$ & 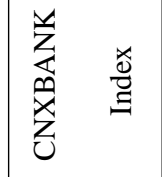 & ò & $\stackrel{?}{\stackrel{q}{p}}$ & 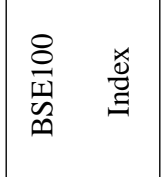 & 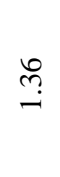 & $\stackrel{\vec{n}}{i}$ & 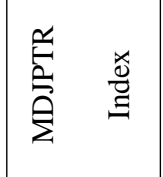 & 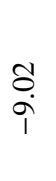 & $\begin{array}{c}\text { aे } \\
\text { i }\end{array}$ & 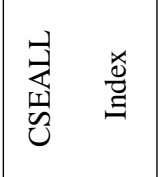 & $\stackrel{9}{9}$ & $\widehat{\sigma}$ \\
\hline 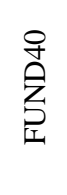 & 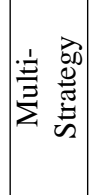 & $\begin{array}{l}\bar{J} \\
\text { ô } \\
\text { U }\end{array}$ & $\begin{array}{l}\text { ț } \\
\stackrel{0}{0}\end{array}$ & $\ddot{\sigma}$ & $=$ & 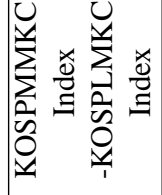 & $\stackrel{0}{0}$ & $\stackrel{\mathbb{N}}{\stackrel{f}{*}}$ & $\begin{array}{ll}\stackrel{\widehat{E}}{\mathrm{E}} \\
\mathrm{Z}\end{array}$ & $\stackrel{n}{0}$ & $\tilde{n}$ & 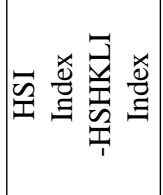 & กี & $\begin{array}{l}\stackrel{+}{\infty} \\
i\end{array}$ & 至 & $\stackrel{\infty}{0}$ & $\stackrel{\infty}{n}$ \\
\hline 空 & 竞 & 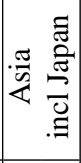 & $\stackrel{t}{\stackrel{0}{0}}$ & $\stackrel{8}{0}$ & ñ & 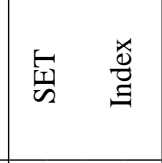 & 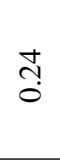 & $\stackrel{\infty}{+}$ & 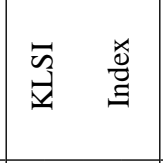 & $\stackrel{9}{9}$ & $\vec{n}$ & $\begin{array}{ll}\frac{1}{\sqrt[n]{N}} \\
\text { N }\end{array}$ & $\stackrel{\substack{0 \\
i}}{i}$ & $\begin{array}{l}\vec{\infty} \\
i \\
i\end{array}$ & 总 & 浐 & $\begin{array}{l}\underset{\sigma}{0} \\
\text { i }\end{array}$ \\
\hline 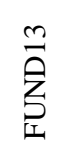 & 至 & 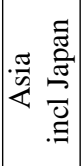 & $\stackrel{8}{:}$ & $\stackrel{8}{0}$ & $\stackrel{\hat{\imath}}{\hat{i}}$ & 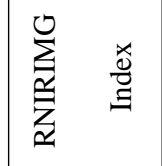 & $\stackrel{m}{0}$ & $\vec{n}$ & 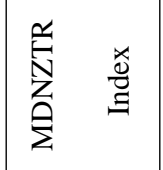 & $\begin{array}{l}\infty \\
\text { in } \\
i\end{array}$ & 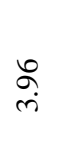 & 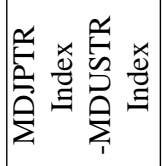 & $\stackrel{?}{=}$ & $\stackrel{\vec{̣}}{r}$ & 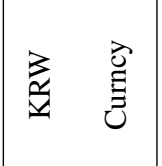 & $\begin{array}{l}n \\
0 \\
i\end{array}$ & $\begin{array}{l}\infty \\
\infty \\
i \\
i\end{array}$ \\
\hline 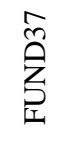 & 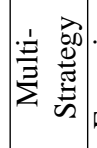 & 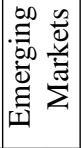 & $\stackrel{8}{8}$ & $\stackrel{\overrightarrow{0}}{\circ}$ & ì & 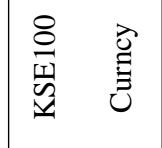 & $\stackrel{2}{0}$ & $\stackrel{f}{\stackrel{f}{f}}$ & 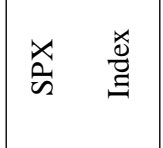 & $\begin{array}{l}0 \\
n \\
i \\
1\end{array}$ & $\underset{b}{0}$ & 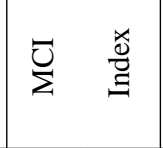 & : & $\begin{array}{l}n \\
\infty \\
i \\
i\end{array}$ & 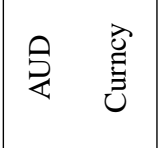 & กี่ & $\begin{array}{l}2 \\
\text { in } \\
i\end{array}$ \\
\hline 总 & 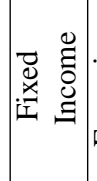 & 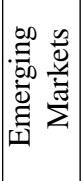 & $\begin{array}{l}5 \\
0 \\
0\end{array}$ & $\stackrel{n}{0}$ & $\vec{m}$ & 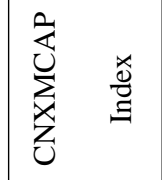 & $\stackrel{2}{3}$ & $\underset{⿱ 乛}{f}$ & 㱐 & $\stackrel{n}{0}$ & $\stackrel{\text { f }}{+}$ & 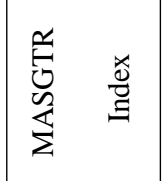 & 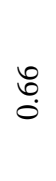 & $\vec{m}$ & 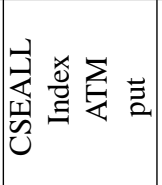 & $\stackrel{\infty}{0}$ & $\stackrel{\circ}{\dot{m}}$ \\
\hline 兑 & 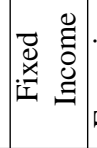 & 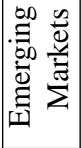 & $\stackrel{5}{6}$ & $\stackrel{\vec{\circ}}{\circ}$ & 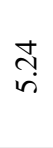 & 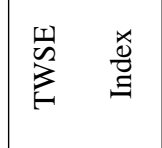 & $\overline{0}$ & ले & 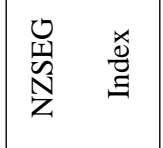 & $\stackrel{n}{0}$ & $\stackrel{\infty}{+}$ & 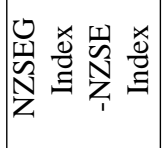 & $\stackrel{\infty}{n}$ & $\stackrel{n}{\ddot{r}}$ & 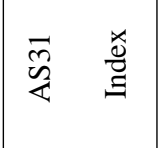 & $\stackrel{\infty}{\dot{0}}$ & $\begin{array}{l}\tilde{\sigma} \\
\tilde{1}\end{array}$ \\
\hline 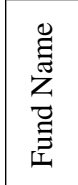 & 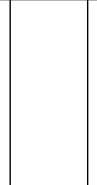 & 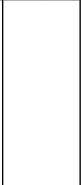 & 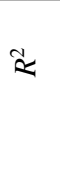 & 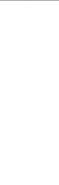 & $\stackrel{\text { 罢 }}{=}$ & 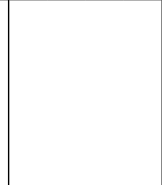 & $\begin{array}{l}\text { 藵 } \\
\text { 监 }\end{array}$ & $\stackrel{\text { 慳 }}{=}$ & 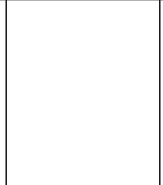 & $\begin{array}{l}\text { 彩 } \\
\text { 管 }\end{array}$ & 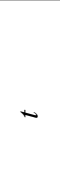 & 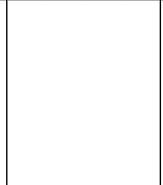 & $\begin{array}{l}\text { 愁 } \\
\text { 照 }\end{array}$ & $\stackrel{\text { 彭 }}{\underline{-}}$ & 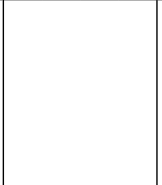 & 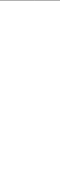 & 塙 \\
\hline
\end{tabular}




\begin{tabular}{|c|c|c|c|c|c|c|c|c|}
\hline $\begin{array}{c}\text { 投資 } \\
\text { 戦略 }\end{array}$ & $\begin{array}{c}\text { Distressed } \\
\text { Debt }\end{array}$ & $\begin{array}{c}\text { Relative } \\
\text { Value }\end{array}$ & $\begin{array}{c}\text { Long / Short } \\
\text { Equities }\end{array}$ & $\begin{array}{c}\text { Fixed } \\
\text { Income }\end{array}$ & $\begin{array}{c}\text { Multi- } \\
\text { Strategy }\end{array}$ & Macro & CTA & $\begin{array}{c}\text { Event } \\
\text { Driven }\end{array}$ \\
\hline $\begin{array}{c}\text { ファンド数 } \\
\text { (総数 39) }\end{array}$ & 4 & 3 & 18 & 3 & 4 & 3 & 3 & 1 \\
\hline $\begin{array}{c}\text { 平均補正 } \\
R^{2} \text { 全体 }\end{array}$ & 0.45 & 0.37 & 0.58 & 0.50 & 0.39 & 0.32 & 0.35 & 0.38 \\
\hline $\begin{array}{c}\text { 平均補正 } \\
R^{2} \text { 前半 }\end{array}$ & 0.64 & 0.57 & 0.65 & 0.74 & 0.60 & 0.64 & 0.59 & 0.51 \\
\hline $\begin{array}{c}\text { 平均補正 } \\
R^{2} \text { 後半 }\end{array}$ & 0.65 & 0.52 & 0.69 & 0.73 & 0.66 & 0.62 & 0.62 & 0.57 \\
\hline
\end{tabular}

表 26: 戦略別回帰分析結果

\begin{tabular}{|c|c|c|c|c|c|c|c|c|}
\hline $\begin{array}{c}\text { 投資 } \\
\text { 対象地域 }\end{array}$ & $\begin{array}{c}\text { Asia } \\
\text { ex-Japan }\end{array}$ & $\begin{array}{c}\text { Asia } \\
\text { incl Japan }\end{array}$ & Korea & Global & $\begin{array}{c}\text { Emerging } \\
\text { Markets }\end{array}$ & $\begin{array}{c}\text { Greater } \\
\text { China }\end{array}$ & $\begin{array}{c}\text { Australia / } \\
\text { New Zealand }\end{array}$ & $\begin{array}{c}\text { Japan } \\
\text { Only }\end{array}$ \\
\hline $\begin{array}{c}\text { ファンド数 } \\
\text { (総数 39) }\end{array}$ & 7 & 7 & 2 & 8 & 5 & 1 & 2 & 7 \\
\hline $\begin{array}{c}\text { 平均補正 } \\
R^{2} \text { 全体 }\end{array}$ & 0.59 & 0.39 & 0.64 & 0.34 & 0.52 & 0.56 & 0.75 & 0.46 \\
\hline $\begin{array}{c}\text { 平均補正 } \\
R^{2} \text { 前半 }\end{array}$ & 0.73 & 0.62 & 0.78 & 0.56 & 0.75 & 0.69 & 0.83 & 0.35 \\
\hline $\begin{array}{c}\text { 平均補正 } \\
R^{2} \text { 後半 }\end{array}$ & 0.73 & 0.67 & 0.57 & 0.64 & 0.70 & 0.66 & 0.76 & 0.58 \\
\hline
\end{tabular}

表 27: 地域別回帰分析結果 


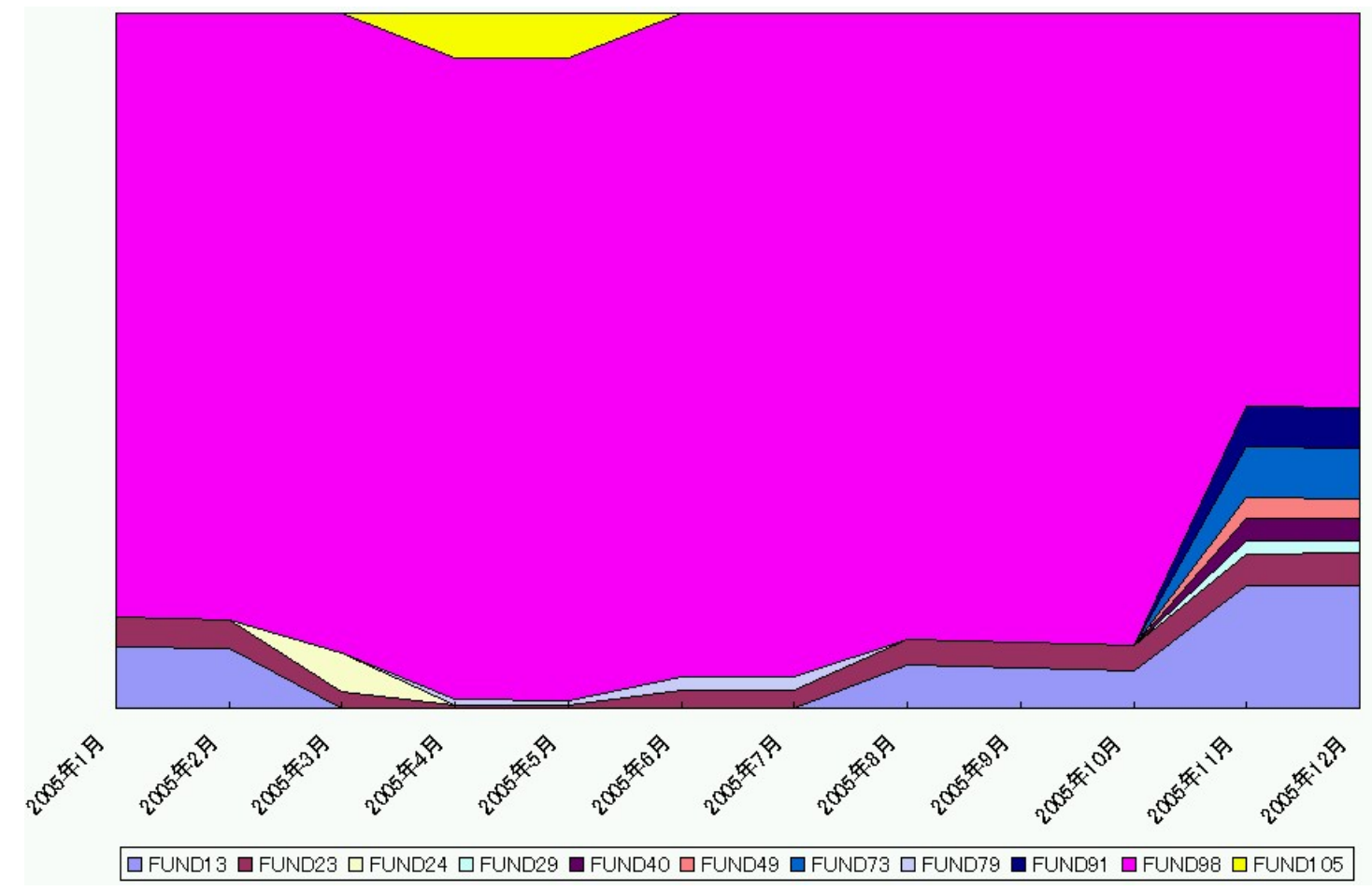

图 19: 2005 の CDD 最適ポートフォリオ (リスク許容度 $0.1 \%$ ) の配分の推移 


\begin{tabular}{|c|c|c|c|c|}
\hline ファンド名 & FUND13 & FUND23 & FUND24 & FUND98 \\
\hline 投資戦略 & $\begin{array}{l}\text { Multi- } \\
\text { Strategy }\end{array}$ & Macro & $\begin{array}{l}\text { Long / Short } \\
\text { Equities }\end{array}$ & $\begin{array}{l}\text { Event Driven } \\
\text { Driven }\end{array}$ \\
\hline $\begin{array}{c}\text { 投資対象 } \\
\text { 地域 }\end{array}$ & $\begin{array}{c}\text { Asia } \\
\text { incl Japan }\end{array}$ & $\begin{array}{c}\text { Asia } \\
\text { incl Japan }\end{array}$ & $\begin{array}{l}\text { Greater } \\
\text { China }\end{array}$ & Global \\
\hline 補正 $R^{2}$ & 0.75 & 0.74 & 0.74 & 0.78 \\
\hline 切片 & 0.01 & 0.17 & 0.01 & 0.03 \\
\hline $\mathrm{t}$ 値 & 2.15 & 5.98 & 1.06 & 16.66 \\
\hline 説明変数 1 & $\begin{array}{l}\text { RNIRIMG } \\
\text { Index }\end{array}$ & $\begin{array}{l}\text { BSE100 } \\
\text { Index }\end{array}$ & $\begin{array}{l}\text { SIBSB } \\
\text { Index }\end{array}$ & $\begin{array}{c}\text { IDR } \\
\text { Curncy }\end{array}$ \\
\hline 係数 & 0.93 & 2.63 & 0.78 & -0.38 \\
\hline $\mathrm{t}$ 値 & 7.03 & 7.32 & 5.64 & -5.24 \\
\hline 説明変数 2 & $\begin{array}{c}\text { RNIRIS } \\
\text { Index } \\
\text {-RNIRIL } \\
\text { Index }\end{array}$ & $\begin{array}{l}\text { CSEALL } \\
\text { Index } \\
\text { OTM } \\
\text { call }\end{array}$ & $\begin{array}{c}\text { SHBSHR } \\
\text { Index }\end{array}$ & $\begin{array}{c}\text { THB } \\
\text { Curncy }\end{array}$ \\
\hline 係数 & -1.37 & 0.43 & -0.74 & -0.56 \\
\hline $\mathrm{t}$ 值 & -5.85 & 5.33 & -3.06 & -3.63 \\
\hline 説明変数 3 & $\begin{array}{l}\text { JAKISL } \\
\text { Index }\end{array}$ & $\begin{array}{l}\text { BTSRI } \\
\text { Index }\end{array}$ & $\begin{array}{c}\text { HKSPGEM } \\
\text { Index }\end{array}$ & $\begin{array}{c}\text { SGD } \\
\text { Curncy }\end{array}$ \\
\hline 係数 & 0.37 & -3.47 & 0.32 & 0.62 \\
\hline $\mathrm{t}$ 值 & 4.79 & -4.90 & 2.45 & 3.44 \\
\hline 説明変数 4 & $\begin{array}{l}\text { NIFTY } \\
\text { Index }\end{array}$ & $\begin{array}{c}\text { CNXBANK } \\
\text { Index }\end{array}$ & $\begin{array}{c}\text { SHBSHR } \\
\text { Index } \\
\text { ATM } \\
\text { put }\end{array}$ & $\begin{array}{c}\text { MATWTR } \\
\text { Index }\end{array}$ \\
\hline 係数 & -0.43 & -1.05 & -0.02 & 0.58 \\
\hline $\mathrm{t}$ 値 & -4.74 & -4.15 & -2.23 & 3.42 \\
\hline
\end{tabular}

表 28: 2005.1-3 の各ファンドのエクスポージャー 


\begin{tabular}{|c|c|c|c|c|}
\hline ファンド名 & FUND23 & FUND79 & FUND98 & FUND105 \\
\hline 投資戦略 & Macro & CTA & $\begin{array}{l}\text { Event } \\
\text { Driven }\end{array}$ & $\begin{array}{l}\text { Long / Short } \\
\text { Equities }\end{array}$ \\
\hline $\begin{array}{c}\text { 投資対象 } \\
\text { 地域 }\end{array}$ & $\begin{array}{c}\text { Asia } \\
\text { incl Japan }\end{array}$ & Global & Global & $\begin{array}{c}\text { Asia } \\
\text { ex-Japan }\end{array}$ \\
\hline 補正 $R^{2}$ & 0.73 & 0.62 & 0.80 & 0.90 \\
\hline 切片 & 0.17 & -0.01 & 0.02 & 0.02 \\
\hline $\mathrm{t}$ 値 & 5.52 & -0.68 & 15.40 & 5.08 \\
\hline \multirow{2}{*}{ 説明変数 1} & BSE100 & EUR & IDR & SIBSB \\
\hline & Index & Curncy & Curncy & Index \\
\hline 係数 & 2.61 & 1.41 & -0.35 & 0.70 \\
\hline $\mathrm{t}$ 値 & 6.96 & 5.05 & -5.81 & 7.19 \\
\hline \multirow{2}{*}{ 説明変数 2} & $\begin{array}{l}\text { CSEALL } \\
\text { Index }\end{array}$ & KSE100 & KOSPI & KLSI \\
\hline & $\begin{array}{c}\text { OTM } \\
\text { call }\end{array}$ & Index & Index & Index \\
\hline 係数 & 0.42 & 0.37 & 0.11 & 0.73 \\
\hline $\mathrm{t}$ 値 & 5.14 & 3.39 & 4.40 & 7.04 \\
\hline \multirow{2}{*}{ 説明変数 3} & BTSRI & SXXP & HKD & $\begin{array}{l}\text { SIBSB } \\
\text { Index }\end{array}$ \\
\hline & Index & Index & Curncy & $\begin{array}{l}\text { ATM } \\
\text { call }\end{array}$ \\
\hline 係数 & -3.60 & -0.73 & -3.23 & -0.02 \\
\hline $\mathrm{t}$ 值 & -4.34 & -2.61 & -4.28 & -4.08 \\
\hline \multirow{2}{*}{ 説明変数 4} & CNXBANK & $\mathrm{CNY}$ & DHAKA & $\begin{array}{l}\text { NZSE } \\
\text { Index }\end{array}$ \\
\hline & Index & Curncy & Index & $\begin{array}{l}\text { OTM } \\
\text { call }\end{array}$ \\
\hline 係数 & -1.01 & -323.19 & -0.04 & -0.01 \\
\hline $\mathrm{t}$ 值 & -3.75 & -1.32 & -1.96 & -3.73 \\
\hline
\end{tabular}

表 29: 2005.4-6 の各ファンドのエクスポージャー 


\begin{tabular}{|c|c|c|c|c|}
\hline ファンド名 & FUND13 & FUND23 & FUND79 & FUND98 \\
\hline 投資戦略 & $\begin{array}{l}\text { Multi- } \\
\text { Strategy }\end{array}$ & Macro & CTA & $\begin{array}{l}\text { Event } \\
\text { Driven }\end{array}$ \\
\hline $\begin{array}{c}\text { 投資対象 } \\
\text { 地域 }\end{array}$ & $\begin{array}{c}\text { Asia } \\
\text { incl Japan }\end{array}$ & $\begin{array}{c}\text { Asia } \\
\text { incl Japan }\end{array}$ & Global & Global \\
\hline 補正 $R^{2}$ & 0.84 & 0.70 & 0.58 & 0.57 \\
\hline 切片 & 0.01 & 0.03 & 0.02 & 0.02 \\
\hline $\mathrm{t}$ 值 & 2.10 & 2.38 & 1.68 & 9.71 \\
\hline 説明変数 1 & $\begin{array}{l}\text { RNIRIMG } \\
\text { Index }\end{array}$ & $\begin{array}{c}\text { MDJPTR } \\
\text { Index } \\
\text {-MDUSTR } \\
\text { Index }\end{array}$ & $\begin{array}{c}\text { RNIRIS } \\
\text { Index } \\
\text {-RNIRIL } \\
\text { Index }\end{array}$ & $\begin{array}{c}\text { DOLLEX } \\
\text { Index }\end{array}$ \\
\hline 係数 & 1.17 & -9.21 & -2.10 & 0.10 \\
\hline $\mathrm{t}$ 值 & 7.42 & -6.35 & -4.59 & 3.83 \\
\hline 説明変数 2 & $\begin{array}{c}\text { MDNZTR } \\
\text { Index }\end{array}$ & $\begin{array}{c}\text { MASGTR } \\
\text { Index }\end{array}$ & $\begin{array}{l}\text { JAKISL } \\
\text { Index } \\
\text { OTM } \\
\text { call }\end{array}$ & Curncy \\
\hline 係数 & 2.78 & -4.85 & 0.02 & 0.24 \\
\hline $\mathrm{t}$ 値 & 6.86 & -3.99 & 4.00 & 3.03 \\
\hline 説明変数 3 & $\begin{array}{l}\text { MATWTR } \\
\text { Index } \\
\text {-MDUSTR } \\
\text { Index }\end{array}$ & $\begin{array}{c}\text { MASKTR } \\
\text { Index } \\
\text {-MDUSTR } \\
\text { Index }\end{array}$ & $\begin{array}{l}\text { DEFTY } \\
\text { Index }\end{array}$ & $\begin{array}{l}\text { SPX } \\
\text { Index }\end{array}$ \\
\hline 係数 & 1.72 & 3.41 & -0.49 & -0.22 \\
\hline $\mathrm{t}$ 値 & 6.00 & 2.39 & -3.31 & -2.49 \\
\hline 説明変数 4 & $\begin{array}{c}\text { RNIRISV } \\
\text { Index }\end{array}$ & $\begin{array}{c}\text { MATWTR } \\
\text { Index }\end{array}$ & $\begin{array}{c}\text { RNIRISV } \\
\text { Index } \\
\text { ATM } \\
\text { put }\end{array}$ & $\begin{array}{c}\text { SZBSHR } \\
\text { Index }\end{array}$ \\
\hline 係数 & -0.79 & -4.73 & -0.04 & 0.06 \\
\hline $\mathrm{t}$ 值 & -5.39 & -2.33 & -2.63 & 1.98 \\
\hline
\end{tabular}

表 30: 2005.7-9 の各ファンドのエクスポージャー 


\begin{tabular}{|c|c|}
\hline 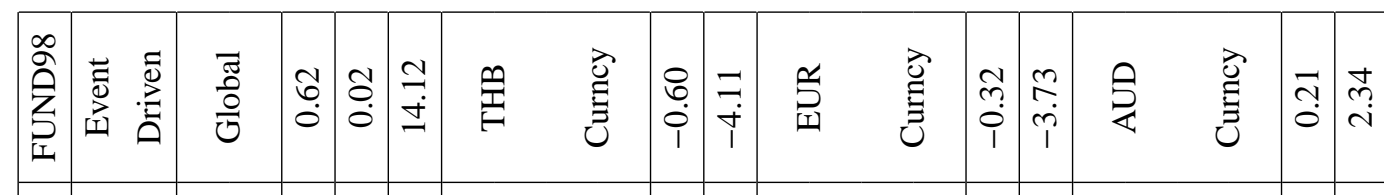 & \\
\hline 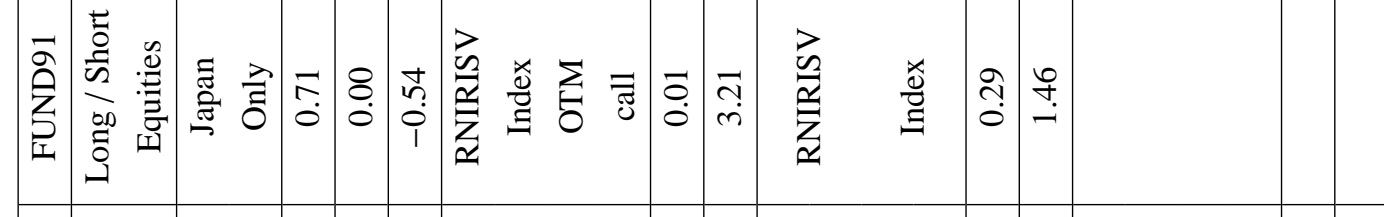 & \\
\hline 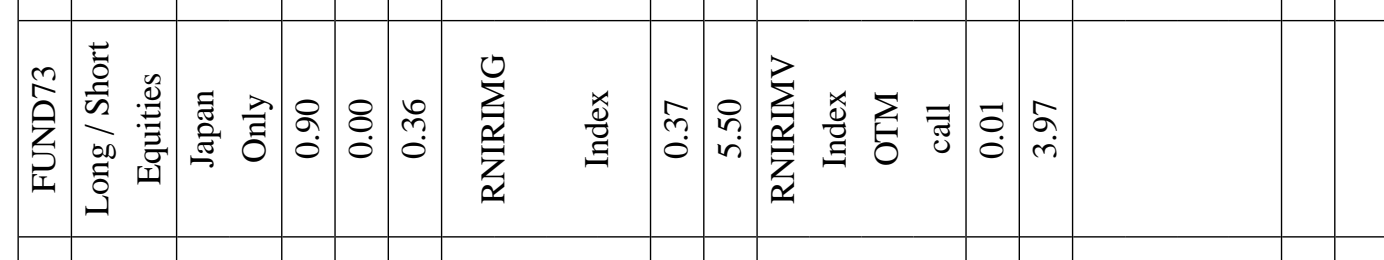 & \\
\hline 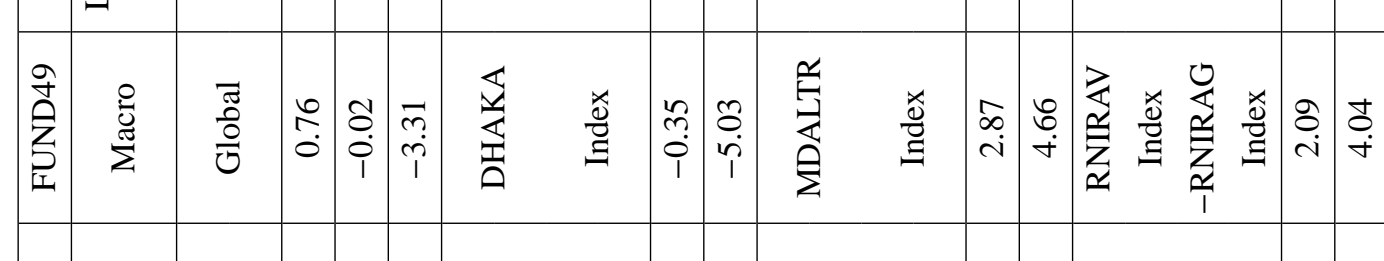 & 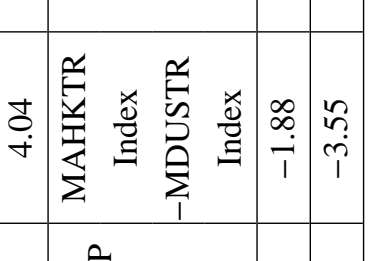 \\
\hline 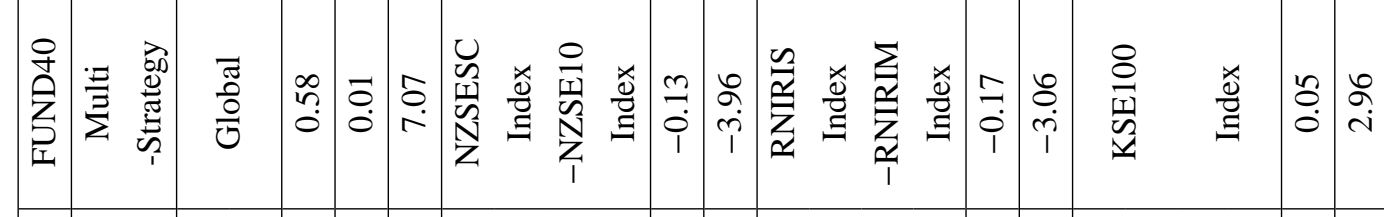 & \\
\hline 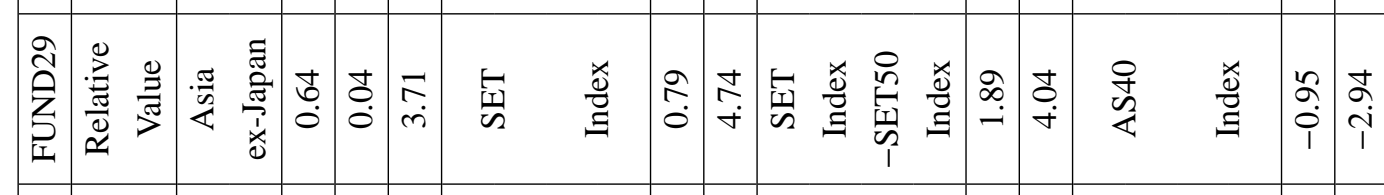 & \\
\hline 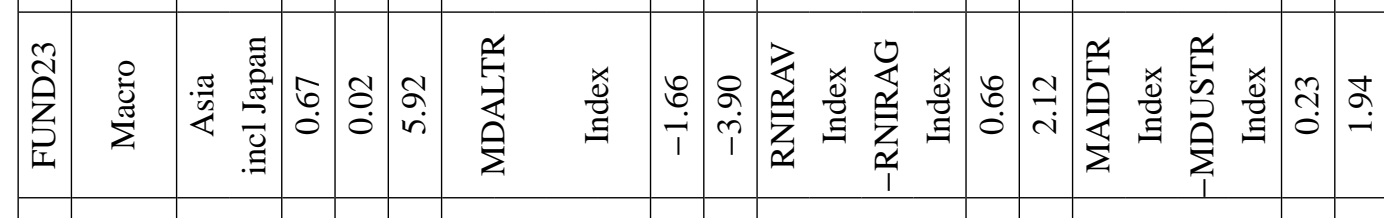 & \\
\hline 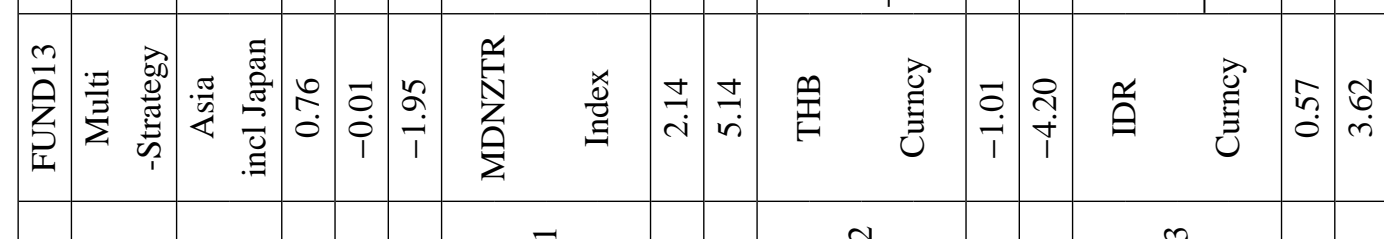 & \\
\hline 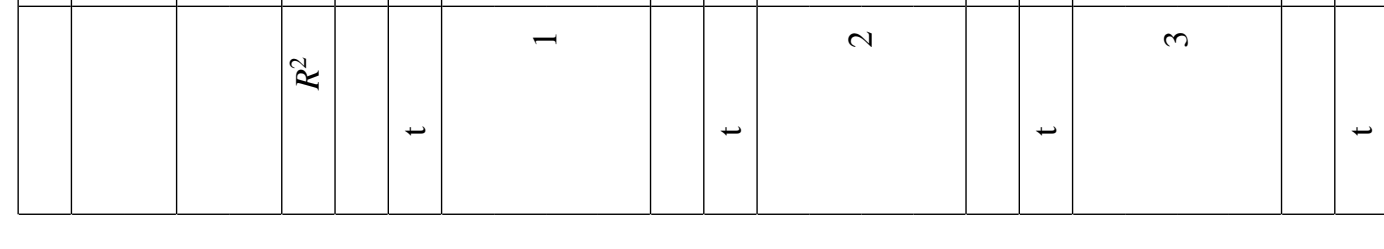 & \\
\hline
\end{tabular}

表 31: 2005.10-12 の各ファンドのエクスポージャー 